Hows, Whys, AND But-Fors: TheOrIZING, COMPARING, AND SOLUTION FINDING Within the Principle Of Material Contribution To Risk In The LAw Of NEGLIGENCE

by

Lachlan Caunt

B.A., Australian National University, 2012

L.L.B. (Hons), Australian National University 2013

\begin{abstract}
A THESIS SUBMITTED IN PARTIAL FULFILLMENT OF
THE REQUIREMENTS FOR THE DEGREE OF
\end{abstract}

\begin{abstract}
MASTER OF LAWS
in

THE FACULTY OF GRADUATE AND POSTDOCTORAL STUDIES

(Law)

THE UNIVERSITY OF BRITISH COLUMBIA

(Vancouver)
\end{abstract}

December 2015

(C) Lachlan Caunt, 2015 


\begin{abstract}
This thesis will provide a significant and original contribution to the scholarship on tort causation. Material contribution to risk is a principle of tort causation; yet has never been applied. It may potentially violate all of the principles that underpin tort causation, whatever those principles may be. Alternately, it may simply be another conventional adaptation of tort causation to avoid manifest injustice. The supposition is that it will fall somewhere between. This thesis contributes to the literature converting this supposition into knowledge. This thesis has three parts. The first seeks to do what few in tort writing do: craft a methodology. The first part compares and contrasts the theory that underpins tort law, the law of negligence, and finally, the theory of causation. Any choice in the latter part of the article is obviously conditioned on which theory explains the actual benefits and harms of such a choice. The second part uses comparison to determine where the Canadian law of material contribution to risk currently rests. By showing the fundamental dissimilarities between the Canadian and UK jurisprudence, this part shows that the two jurisdictions are, and should continue to be, unique. The third part considers two areas of material contribution to risk that are fundamentally unclear. Firstly, circumstances in which material contribution to risk can apply in lieu of the de facto but-for test are, at best, transparent. This section is termed the 'trigger' section—and probes when material contribution to risk can be applied instead of the de facto but-for test. Secondly, who is liable for what under material contribution to risk is also unclear. This section is termed apportionment-and determines which liability rule should determine which defendant should be liable for what share of the damages. This thesis makes an original contribution to the literature by defining the underlying theory of causation in negligence through the application of robust methodology; defining the Canadian law of material contribution to risk; and finally,
\end{abstract}


establishing both what the trigger is, and what apportionment should be, in relation to material contribution to risk. 


\section{Preface}

This dissertation is an original, unpublished, intellectual product of the author Lachlan Caunt. 


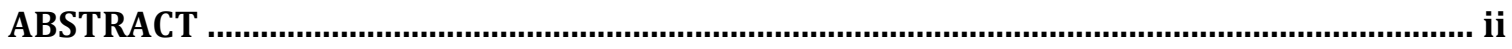

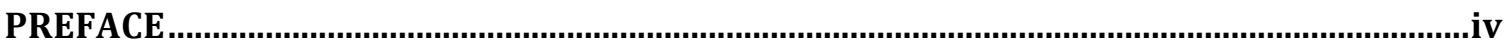

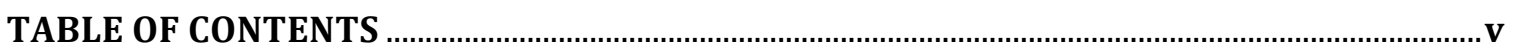

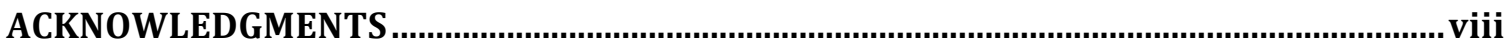

I INTRODUCTION

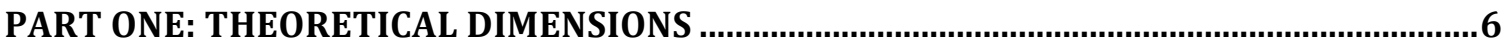

II WHAT IS IN THIS THESIS, AND WHAT IS NOT IN THIS THESIS: AN AMBIT BRIEF .......6

III DEFINING THE ESSENCES OF THE TOPIC

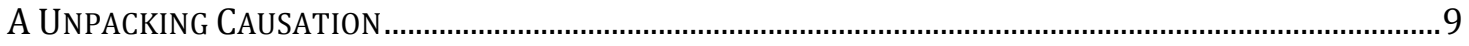

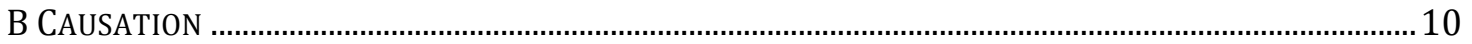

1 Factual Cause

2 Legal Cause

C RETURNING TO DEFINE CAUSATION

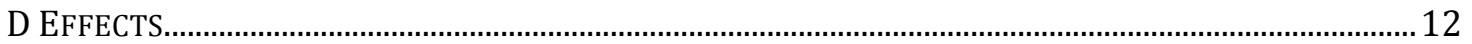

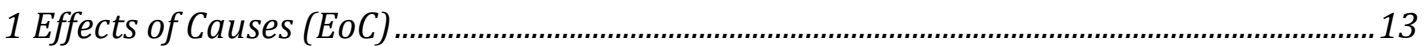

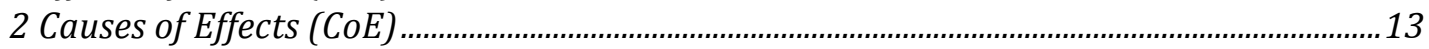

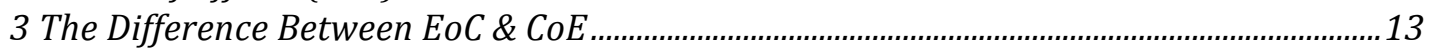

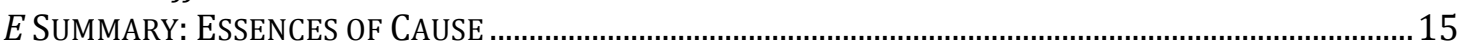

IV DISENTANGLING THE GORDIAN KNOT: PARSING THE THEORETICAL THREADS OF

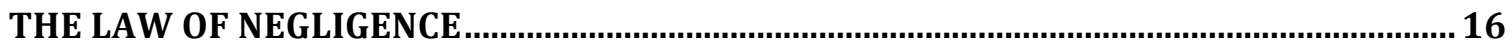

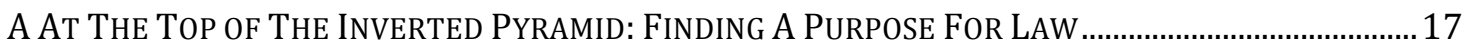

B At THE Middle of THE INVERTEd PyRAMId: Divining THE GoOd AND GOALS OF NEGLigENCE

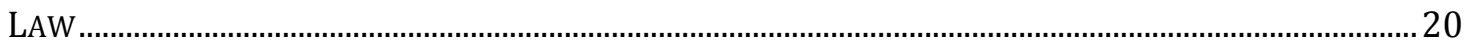

1 Limiting The Ambit to the Law of Negligence Specifically, Not Tort Generally.................20

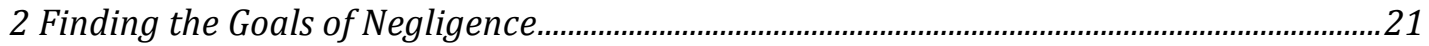

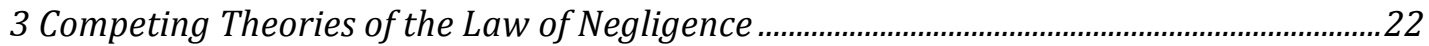

4 Choosing and Defending a Theory of Negligence: Corrective Justice or Instrumentalism?

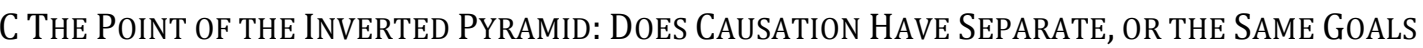

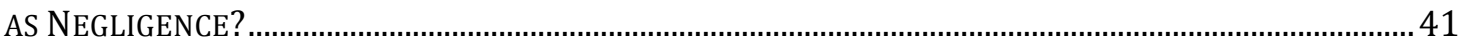

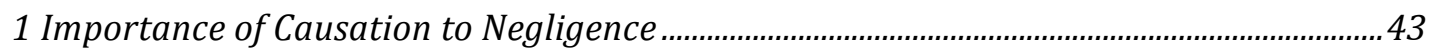

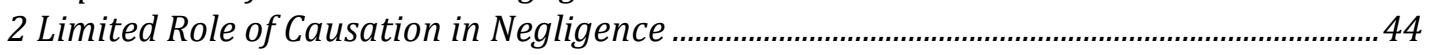

3 Reaching the Terminus: The Purpose of Causation in Negligence. .......................................49

D A CAVEAT: NEGLIGENCE IS UNDERPINNED BY CORRECTIVE JUSTICE, BUT THE WORLD IS NOT .......50



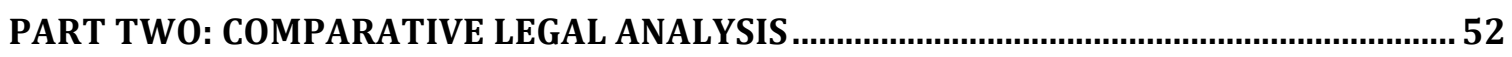

V BUT-FOR IS NOT HEGEMONIC \& MATERIAL CONTRIBUTION TO RISK IS NOT SO

SCARY AFTER ALL: OUTLAYING THE DIFFERENT TESTS FOR CAUSATION ..................... 52

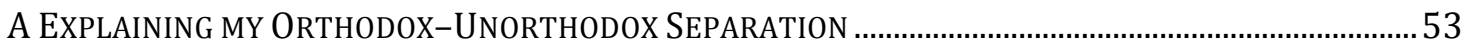

B CAUSAL TEST 1: ORTHODOX BUT-FOR CAUSATION ...............................................................................54

C CAUSAL TEST 2: UNORTHODOX BUT-FOR—'BURDEN SHIFTING BUT-FOR' ........................................55

$D$ CAUSAL TEST 3: UNORTHODOX BUT-FOR—'STANDARD SHIFTED BUT-FOR' .......................................57

1 Learned Intermediary Based Unorthodox But-for 
E CAUSAL TEST 4: MATERIAL CONTRIBUTION TO RISK

\section{VI: FURTHERING THE METHODOLOGY: MAKING APPOSITE COMPARISONS BETWEEN}

THE UK AND CANADA

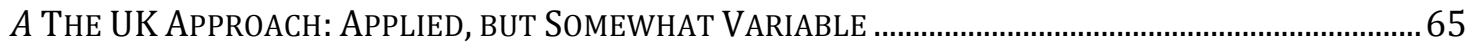

1 McGee v National Coal Board (1973): Starting Material Contribution ................................65

2 Fairchild v Glenhaven Funeral Services (2002): Confirming Material Contribution,

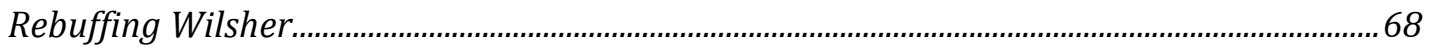

3 Gregg v Scott: Beginning to Limit Material Contribution to Risk to Mesothelioma ......... 72

4 Barker v Corus (2006): Upholding Fairchild Somewhat, But Considering Apportionment

5 Compensation Act 2006: Limiting, Seemingly Material Contribution to Risk to

Mesothelioma Related Harms...................................................................................................... 78

6 Sienkiewicz v Greif (2011): Bringing Single Source Wrongful Harm Cases into the

(Asbestos Lined) Tent....................................................................................................................82

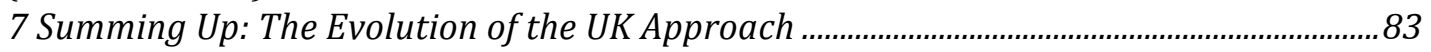

$B$ THE CANADIAN APPROACH: NEVER APPLIED, BUT WILDLY VARIABLE................................................ 85

1 Snell v Farrell (1990): Inching Open the Gate for Material Contribution? ..........................86

2 Athey v Leonati (1996): A Confusing Trilogy: Part 1..........................................................8

3 Walker Estate v York Finch General Hospital (2001): A Confusing Trilogy Part 2.......... 92

4 Resurfice Corp v Hanke (2007): A Confusing Trilogy: Part 3...............................................93

5 Clements $v$ Clements (2012): Clearing Up Confusing, Finally-One Hopes......................... 96

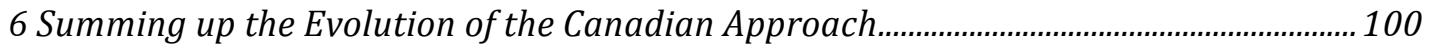

C DOING THE COMPARISON: WHAT USEFUL CONTRASTS AND COMMONALITIES CAN BE OBSERVED

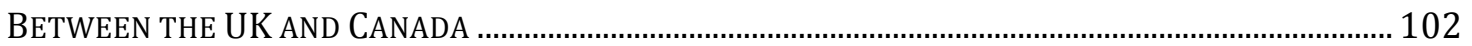

1 Commonality: Both Jurisdictions Find This Exceedingly Difficult......................................103

2 Contrast: There Is a Fundamentally Different Legal Environment.................................... 104

3 Contrast: The Legal History of Material Contribution To Risk Diverges Widely Between

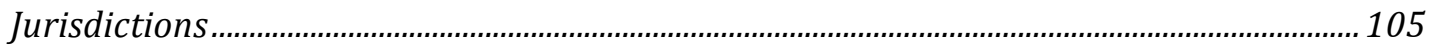

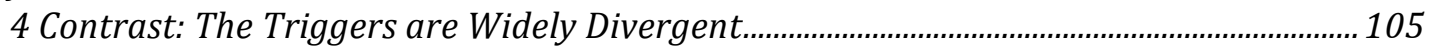

5 Contrast: Conceptions of The Apportionment Rules May Be Distinct ................................ 106

6 Commonality: The Jurisprudence Now Seems Stable in Both Jurisdictions....................... 108

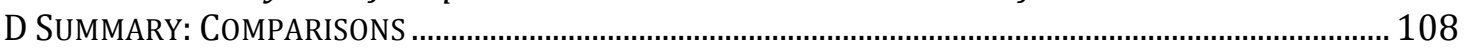

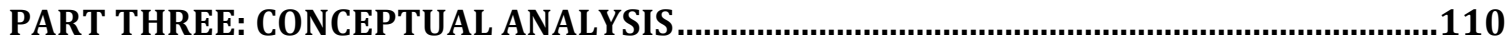

VII FINDING BOTH THE 'HOW' AND THE 'WHY' FOR TRIGGERING MATERIAL

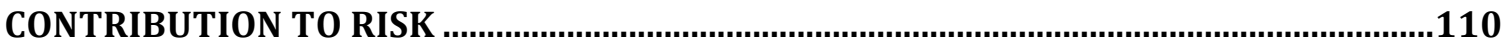

B ANSWERING THE CLARITY QUESTIONS: CLARIFYING THE BOUNDS OF THE TRIGGER ...................... 112

1 Question 1: Does the Harm Have to Be Mesothelioma?....................................................... 113

2 Question 2: Can Material Contribution To Risk Expand Beyond Circular and

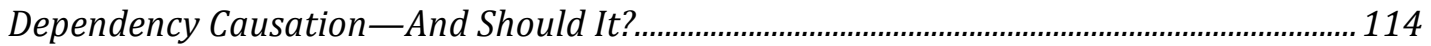

3 Question 3: Surely Material Contribution To Risk is Not Limited to Multiple Tortfeasor

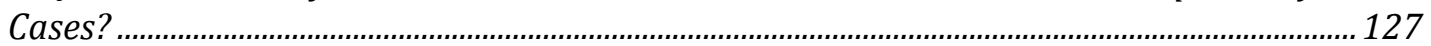

4: Looking to the Systemic effects of Material Contribution to Risk in Unorthodox

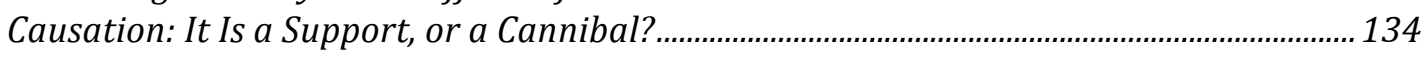

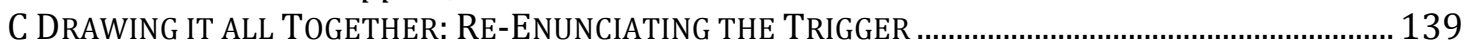

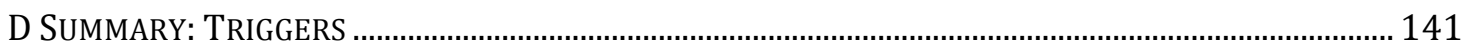

VIII HIC SUNT DRAGONES: WORKING THROUGH APPORTIONMENT ............................142

A THE APPORTIONMENT POSITION UNDER THE BUT-For CAUSAL TESTS ........................................... 143 
1 Single Tortfeasor But-For.

2 Multiple Tortfeasor But-For

$B$ SHOUld THE APPORTIONMENT RULES FROM But-For CAUSAl TESTS Simply BE TRANSPORTED to

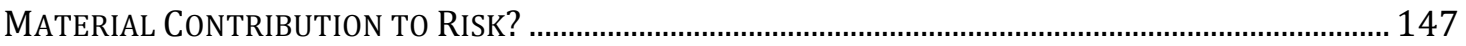

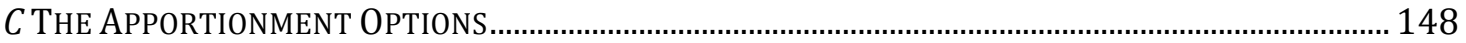



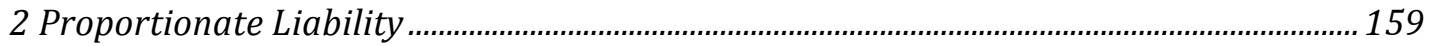

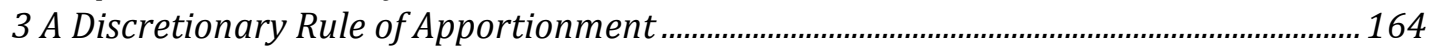

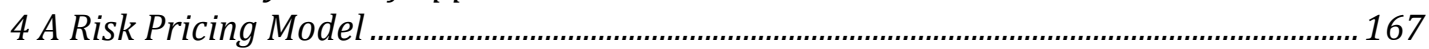

D SUMMARIZING THE APPORTIONMENT OPTIONS …....................................................................... 171

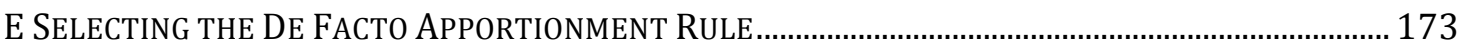



2 Evaluating The Apportionment Options Against the Selection Criteria ............................ 174

F ATTEMPTING A MOdEST IMPROVEMENT OF PROPORTIONATE LiabiLiTY: AdDING A MinUTIAE OF

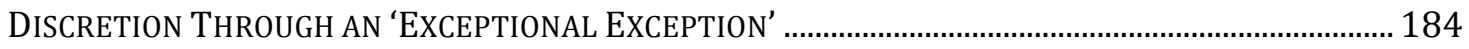

1 The First Limb: Special Injustice to the Plaintiff .......................................................................... 185

2 The Second Limb: Special Moral Wrongdoing by the Defendant......................................186

3 The Judicial Alteration is Fixated on Defendant Blameworthiness: Not Plaintiff

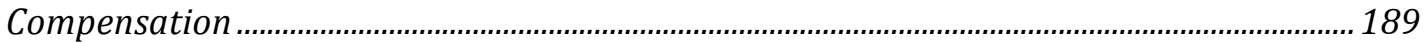

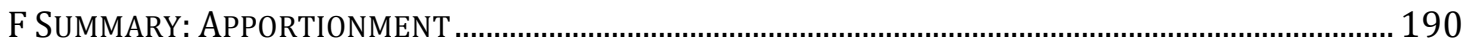

IX: CONCLUSION

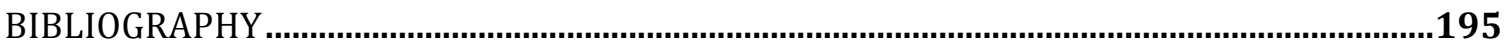




\section{ACKNOWLEDGMENTS}

It would be standard to thank a great many people here; some connected to the creation of this thesis, and some not. For good or ill, standards are not always what should be followed; and certainly not what I follow. To Joost, Bruce, Ljiljana, Joanne, the Law Librarians, Gerda, Peter, Jeremy, Damien, Krish, and those others I have forgotten who have aided, assisted, and abetted me throughout this least year: thank you. Deeply. I would not thank only if doing so is merely the standard habit. I thank you because I am deeply grateful for your selflessness, grace and kindness. 


\section{INTRODUCTION}

Material contribution to risk has not yet taken corporeal form in Canada. Currently, it exists in its unenlivened form; having never been applied. It is confirmed to exist, ${ }^{1}$ yet it seems spectral. Causation is bedeviled by complex cases_overcoming the complexity and confusion is vital for the law of negligence. ${ }^{2}$ This thesis will make a substantial contribution to the scholarship in tort causation by, in its three parts, crafting an animus for causation through a methodologically sound theory enunciation; showing the unique form of the Canadian material contribution to risk conception; and dispelling the aura of uncertainty in relation to two vital, but fatally misunderstood parts of material contribution to risk.

Material contribution to risk is an alternative test for proving causation in the tort of negligence. ${ }^{3}$ Rather than asking whether the harm suffered by the plaintiff would have happened 'but-for' the negligence of the defendant, material contribution to risk asks if the negligence of the defendant materially contributed to the risk of the plaintiff suffering the kind of injury they did indeed suffer. It is generally known in Canada, and logically obvious, that the material contribution to risk test is easier to satisfy than the but-for test.

If applied injudiciously, material contribution to risk may well be responsible for a rash of lawsuits in which a causal link that would not, and should not be enlivened under the de facto but-for test is enlivened under material contribution to risk. The UK Supreme

\footnotetext{
${ }^{1}$ Barker v Montford Hospital, [2007] 278 DLR (4th) (Ont CA); Jackson v Kelowna General Hospital, [2007] 277 DLR (4th); Seatle v Purvis, [2007] 47 CCLT (3d) 179 (BCCA); Fullowka v Royal Oak Ventures, [2008] 4 NWTCA (NWT CA); Athey v Leonati, [1996] 3 SCR 258; Walker Estate v York Finch General Hospital, 1 SCR 647 (2001); Resurfice Corp v Hanke, [2007] 7 SCC; Clements v Clements, [2012] SCC 32.

${ }^{2}$ Holtby v Brigham \& Cowan, [2000] 3 All ER 421.

${ }^{3}$ In reference to the need to limit the potential expansion of material contribution to risk Sienkiewicz $v$ Greif (UK) Ltd, [2011] 10 UKSC (UK Supreme Court), para 186 (Lord Brown).
} 
Court, found themselves bound to this outcome in Sienkiewicz, Greif, $^{4}$ where despite the defendant materially increasing the risk only from one in 24 million to one in 28.3 million, ${ }^{5}$ he was nonetheless liable for the entirety of the plaintiff's loss. Such perverse results should be avoided, but this thesis notes throughout that material contribution to risk is both an ordinary causal process and a needed one.

To render the abstract, real: consider what is referred to as the three nurses hypothetical. Here, three nurses each separately give a patient a dose of medication, but negligently fail to note that they have done so. The first dose is beneficial, and the second fatal, and the third neither worsens nor ameliorates the patient's condition. Each nurse can state that but-for their negligence, the plaintiff would still have died, as the other two nurses would have ultimately administered the fatal doses. ${ }^{6}$ In this case, the de facto but-for test fails to express the relationship between the wrongdoer and the plaintiff in a way that justifies compensation to the latter from the pocket of the former. ${ }^{7}$ In a great many other circumstances, but-for causation is not a relevantly useful test ${ }^{8}$ - making material contribution to risk a vital part of causation in negligence. ${ }^{9}$

\footnotetext{
4 Sienkiewicz, v Greif (UK) Ltd, supra note 3.

5 Stapleton, Jane, "Factual Causation, Mesothelioma, and Statistical Validity" (2012) 128 Law Q Rev 221 at 222. 6 Jane Stapleton, "Lords A'Leaping Evidentiary Gaps" (2002) 10 Torts Law Journal 276.

7 Snell v Farrell, [1990] 72 DLR (4th) 289 at 326.

8 Mooney v British Columbia (Attorney General), [2004] 25 CCLT (3d) 234 (British Columbia Court of Appeal); Cottrelle v Gerrard, [2003] 20 CCLT (3d) 1 (Ontario Court of Appeal); Hagan v Dalkon Shield Claimants Trust, [1998] 43 CCLT (2d) 11 (Alberta Queens Bench); Sahourin Estate v Watterodt Estate, [2005] 34 CCLT (3d) 193 (British Columbia Court of Appeal); Sohal v Brar, [1998] 3 WWR 553 (Alberta Queens Bench); Stefanshyn v Rubin, [1997] 2 WWR 298 (Manitoba Court of Appeal); Zaba v Sasktatchewan Insitute of Applied Science and Technology, [1997] 8 WWR 414 (Saskatchewan Court of Appeal). This is a cursory, and relatively arbitrary selection of cases. Many more exist. Each case involved a negligent defendant, an injured plaintiff, and an increased risk of injury because of the defendant's negligence. The probabilistic threshold of but-for causation could not-by varying but minor degrees—be met, and thus the cases failed because they could not prove cause.

9 See, for example, Jane Stapleton, “Unnecessary causes” (2013) 129 Law Quarterly Review 39. Her usage of 'useful' and 'not useful' in describing different elements of causation that are normally considered inviolate is a most enlightening approach.
} 
This thesis contains three parts: each serves as an original contribution to the literature. Each focuses on improving the law on material contribution to risk.

The first part applies a rigorous methodology to determine which theory best provides animus for the subject of this thesis: causation in negligence. This part takes form through chapters II, III and IV. Chapter II simply defines the ambit of this thesis; while chapter III provides and defines necessary terms while being conscious of not opening those endlessly embedding matryoska dolls of concepts that are beyond the ambit of this thesis. ${ }^{10}$ Chapter IV provides the substance of this part. To describe a change to the law of negligence as 'good', logically, you must know against which goals 'good' as well as 'bad' change is determined. This determination is only possible by closely engaging with theories of negligence; and in so doing, excluding the goals of putative accounts of negligence that impinge upon the accurate realization of the goals of the genuine accounts of negligence. This contest is seen between instrumentalist and corrective justice theories of negligence, and through this robust theoretical methodology, this section aims to make an original contribution to the literature by divining these general goals, and using them to determine the ultimately appropriate theory.

The second part of the thesis shows what the law of material contribution to risk is in Canada; and, by comparing it to the UK jurisprudence, demonstrates that they are deeply different characterizations. It is tempting to use the fully explained concepts in the UK jurisprudence to paper over cracks in the thin jurisprudence in Canada. This part clearly shows that to do so would be in error. Chapter V outlines and demonstrates the causal tests

\footnotetext{
10 See, for example Richard W Wright, "Causation, responsibility, risk, probability, naked statistics, and proof: Pruning the bramble bush by clarifying the concepts" (1987) 73 Iowa L Rev 1001; Richard W Wright, "The NESS Account of Natural Causation: A Response to Criticisms" (2011) Perspectives on Causation, online: <http://papers.ssrn.com/sol3/papers.cfm?abstract_id=1918405>; Lord Hoffman, "Causation" in Richard Goldberg, ed, Perspectives on Causation (Oxford: Hart Publishing, 2011) 3 at 3 Lord Hoffman notes that the necessary element of a sufficient set (NESS) test propounded by these authors and others, has despite oceans of academic ink being spilled on its behalf, has attracted precisely no judicial interest.
} 
that currently exist. There is significant commonality between the confusion in regard to the admittedly unorthodox test of material contribution to risk and the other unorthodox tests in causation. This chapter gives definition to these tests, and in so doing both shows what they are; and demonstrates that there is nothing foreign about material contribution to risk. Chapter VI does the laborious work of divining what the law on material contribution to risk is in Canada and the UK. Both jurisdictions have had a series of significant cases, each of which has crystallized a key principle. These cases are important ones; yet no Canadian author has yet elaborated on them in both jurisdictions in a single work. This chapter somewhat exhaustively does so this definition and comparative work; and in so doing, provides a clear image in terms of material contribution to risk of the law of Canada; the law of the UK; and why the two jurisdictions are, and should be, distinct.

The third and final part of this thesis closely analyses two areas that have not been understood. The first area has been considered exhaustively by courts, yet this thesis contributes to the literature by asking a series of — currently unresolved—questions, and then providing answers. The second area has been considered not at all, and this thesis breaks new ground in doing so. The first area I term the 'trigger' to material contribution to risk. This area of the law is detailed in chapter VII. As an extraordinary principle of causation, there needs to be something particular in a case to 'trigger' material contribution instead of the usual but-for tests. The 'how' and 'why' for this trigger have only ever been partially defined: this section analyses these definitions, and reforms them to create a new definition of this trigger. Chapter VIII considers the vital area of apportionment of liability. When a defendant is found liable for the injuries under the rigorous test of but-for causation; he is normally expected to pay all of the relevant losses the plaintiff suffered. Material contribution to risk is not as rigorous of a test—so it is far from clear whether the defendant 
be compelled to pay all, or simply part, of the relevant losses. This issue has not been considered in Canada. This section breaks new ground by outlining the options that a court applying material contribution to risk could apply; and then selects and justifies this choice.. Chapter IX concludes this thesis, restating the theoretical, comparative, trigger, and apportionment conclusions reached in the preceding chapters.

Throughout this thesis, one core goal is aimed for: improving the Canadian jurisprudence on causation in negligence. This goal seems like a small, atomistic one-but to the plaintiff in the three nurses hypothetical, and the many other similar plaintiffs, this goal is far from trifling. 


\section{PART ONE: THEORETICAL DIMENSIONS}

\section{WHAT IS IN THIS THESIS, AND WHAT IS NOT IN THIS THESIS: AN AMBIT BRIEF}

Causation in tort is one of the most fundamentally contested areas of law. ${ }^{11}$ In each jurisdiction, different solutions to similar problems engender a patchwork of outcomes. ${ }^{12}$ This thesis is intended to focus on one small piece of this patchwork: material contribution to risk. There are broader, systemic issues with tort law. ${ }^{13}$ This article does not allude to, or concern itself with generalist or theoretical approaches to holistic problems in tort law.

Instead, it aims to bring a clarity to material contribution to risk, and in doing so, make tort law somewhat more coherent. Divining a grand theory of tort is law is beyond this thesis, beyond this author, and, perhaps, beyond any the skills of any author.

This thesis consciously limits itself in two ways. Firstly, it has a geographic limitation. This thesis is concerned firstly, and primarily with the law of Canada. Canada is not alone in facing the problems that give rise to the need for material contribution to risk. Yet, a bird's eye view of material contribution to risk adds nothing but a more distant view of detailed problem. In order to have a close understanding of the principle of material contribution to risk limiting this thesis primarily to Canada is a necessary step. ${ }^{14}$ The roots of material contribution to risk lie in recent history in the United Kingdom. Such roots must be unearthed to understand how material contribution to risk came to survive in Canada. The

${ }^{11}$ Lewis Klar, Tort Law, 5th ed (Toronto: LexisNexis Publishing, 2012) at 443; Jane Stapleton, "The Gist of Negligence: Part II" (1984) 104 LQR 389; Peter Cane, "Morality, Law and Conflicting Reasons for Action" (2012) 71:01 The Cambridge Law Journal 59.

12 David Cheifetz, "The Snell Inference and Material Contribution: Defining the Indefinable And Hunting The Causal Snark” (2002) 30:1 Advocates’ Quarterly 1.

13 See S Green, "The risk pricing principle: a pragmatic approach to causation and apportionment of damages" (2005) 4:3 Law, Probability and Risk 159 at 160-165.

${ }^{14}$ For example, the US took unique, and perhaps sui generis, approach to liability in a case involving mass marketed (and eventually greviously injurious) thalidomide. Causation and liability were directly linked, with liability apportioned to reflect each negligent defendant's share of the market, coining the concept of "market share liability". This approach has not been used a great deal since in the US, or elsewhere. See Sindell v Abbott Laboratories, 607 Pacific Reporter 924, Series 2d (1980). 
United Kingdom is, in many senses, the mother country to Canada: this is especially so in the material contribution to risk. To exclude or ignore the germination of material contribution to risk in the United Kingdom is to exclude or ignore the graft of material contribution to risk in Canada. This thesis thus goes into a detailed examination of the law on material contribution to risk in Canada and the United Kingdom. Only when viewed sideby-side can it be understood where material contribution to risk came from, where it is, and perhaps where it should be going in Canada. The fixation on Canada is a national one. Different provinces have enacted different rules, especially in response to the apportionment of liability. ${ }^{15}$ This thesis does not probe the depths of the provincial differences on apportionment legislation. It may well be that the current legislation on causation can accommodate material contribution to risk; but it very well may not be so. ${ }^{16}$ I skirt this vexed question deliberately; phrasing my analysis and discussion in terms of theory and the common law. Only by doing so can I try to craft a conception of material contribution to risk that is generalizable, and not fettered to any one provincial interpretation or piece of provincial legislation.

The second limitation is a conceptual one. This thesis concerns itself with material contribution to risk, which is itself a component of causation, which is a subset of the law of negligence. The focus on material contribution to risk is necessary to give detail and analysis. The de facto causation test— the but-for test—is not the focus of this paper. Material contribution to risk evolved from inherent shortcomings in the but-for test. ${ }^{17}$ Understanding but-for causation is a necessary part of understanding material contribution

\footnotetext{
${ }^{15}$ See, for eg Alberta Tortfeasors Act, RSA 2000 c t-5 [Alberta Tortfeasors Act]; "Judicial Compensation Act, SBC 2003, с 59",

${ }^{16}$ David Cheifetz, "Black Holes, Aether, and Negligence in the Air: Causation in Negligence in Canada after Clements” (2012) The Advocates' Quarterly, online:

$<$ http://papers.ssrn.com/sol3/papers.cfm?abstract_id=2190071> at 6 .

17 Cheifetz, supra note 12 at 3.
} 
to risk: but, to be abundantly clear, the vagaries of but-for causation are only covered by thesis insofar as they are relevant to material contribution to risk. The other components of a tort of negligence—namely breach, duty of care and general damages—are mentioned only cursorily, if at all. These limitations, hopefully, serve to bring material contribution to risk into close, detailed focus. It is my hope that these, at times artificial, limitations will allow the reader to appreciate the depth of the subject at hand without being beguiled by the breadth of issues in tort law generally. 


\section{Defining THE EsSEnCES OF THE TOPIC}

This section will define the concepts needed to be understood in order to make sense of the rest of this thesis. The concepts of causation seem, at times, akin to a matryoska dolls. Within each term, there is another, and within that, another, and on ad nauseum. Here, I attempt to define only the concepts that are absolutely needed, without unpacking more than needed.

In providing key definitions, I am being deliberately pointed in my selections of which terms to define, and which to leave undefined. There are detailed, esoteric concepts that apply to the latter questions of triggers and apportionment. I define these concepts in their place: their relevant section. Here, I define what is needed to be defined in regards to causation itself.

\section{A Unpacking Causation}

Causation has been fundamentally contested perhaps moreso than any other subject in private law. ${ }^{18}$ Law has not really adequately dealt with the variety of inquiries that are involved in causation. ${ }^{19}$ The academy has taken one-overly formalistic-path, in which causation is considered to be constituted by two subsidiary concepts, that of factual and legal cause. ${ }^{20}$ The judiciary has taken another path, thinking of causation as a hazy, nebulous whole, with no constituent parts. ${ }^{21}$ Neither position really encompasses what causation does in the law of negligence, but both passably approximate it. ${ }^{22}$ Here, I attempt to give a

\footnotetext{
18 Arthur Ripstein, "Tort Law in a Liberal State” (2007) 1:2 Journal of Tort Law, online: <http://www.degruyter.com/view/j/jtl.2007.1.2/jtl.2007.1.2.1049/jtl.2007.1.2.1049.xml> at 2.

${ }^{19}$ Calabresi neatly summed up the general mood to judicial approaches to causation when he termed it a "weasel word" Guido Calabresi, The Costs of Accidents: A Legal and Economic Analysis (New Haven: Yale University Press, 1970) at 6.

${ }^{20}$ Ernest Weinrib, “A Step Forward in Factual Causation” (1975) 38 Modern Law Review 518.

${ }^{21}$ Hoffman, supra note 10 at 3.

22 Stapleton, Jane, "Scientific and Legal Approaches to Causation" in Ian Freckleton, ed, Causation In Law And Medicine (Hampshire: Ashgate Publishing) 14 at 17.
} 
relatively simple working definition of causation, and the two inquiries that go to making, or precluding, a conclusion of 'causation' in the legal context.

\section{B Causation}

Causation is, at the bottom, an inquiry about how something came about in the world. Causation in science asks a very specific question: what precise physical matters were required to bring about a transition from one state to another. ${ }^{23}$ This transition may ask how a piece of paper came from sitting on a desk to lying in a wastebasket, or it may ask how that piece of paper went from sitting in a wastebasket to being aflame in that wastebasket.

Causation in science is a very different question, and, unhelpfully, mimics, but does not copy the inquiry that science undertakes. Rather than asking how, for example, the paper moved, or caught aflame, causation seeks a targeted inquiry: it seeks to identify whether the defendant was responsible for that transition. If the defendant is found not be responsible for that transition, even if the actual 'cause' of the transition is still a mystery, a court is satisfied, while obviously a scientist would be vexed. Causation in law is ably stated in this way: "Causation is an expression of the relationship that must be found to exist between the tortious act of the wrongdoer and the injury to the victim in order to justify compensation of the latter out of the pocket of the former" ${ }^{24}$

The three words I emphasized get to the heart of defining the causation inquiry at law. It looks to the relationship between the wrongdoer and victim, and asks whether there is a justification for finding the former liable in damages to the latter. The fact that this extract adheres so closely to the terms used in corrective justice reiterates the symbiotic relation

${ }^{23}$ Jane Stapleton, “Choosing What We Mean by 'Causation' in the Law” (2008) 73:2 Missouri Law Review 433 at 436.

24 Snell v Farrell, supra note 7 at 288-289 (Emphasis author's own). 
between the two. Within this relational inquiry, there are, ultimately, two inquiries. The first inquiry follows the path of the scientific inquiry I referred to earlier in the page: it asks how, physically, an outcome came about. The second inquiry asks a far less precise question: whether the defendant should be considered to have been relevantly involved, and thus responsible, for this transition. At its base, this is the definition of causation: how a transition came about, and whether the defendant should be considered legally responsible for this transition. The two inquiries are often — unhelpfully — termed factual cause and legal cause.

\section{Factual Cause}

Factual cause asks how a transition came about. It accords with "objective notions of physical science". ${ }^{25}$ To follow on with the flaming paper allegory, in a negligence inquiry, the factual causation inquiry would ask what 'caused' the paper to go from it's previous, normal state, to its latter, flaming state. This inquiry would implicate the match, as well as the presence of oxygen to permit the match to light, gravity to let the match to fall, the cleaner's omission to empty the wastepaper basket, the manufacturer of both the paper and the match, and on and on ad infinitum. Factual cause is an inquiry in which the necessary conditions for the specified outcome are ascertained.

\section{Legal Cause}

Legal cause is a rather less defined inquiry. Further expanding upon the flaming paper allegory, the Big Bang is obviously not tortuously liable for the presence of oxygen and gravity; nor is the cleaner-except in certain circumstances—liable for the commonplace omission of not fully emptying the basket; neither is the manufacturer of paper or match. The legal causation inquiry asks: "of all the myriad factors that came about to produce that

\footnotetext{
25 Caroline Sappideen \& Prue Vines, eds, Fleming's The Law of Torts, 10th ed (Sydney: Lawbook Co, 2011) at 227.
} 
transition, which ones seem... to be important to the purpose we have at hand?" ${ }^{26}$ Legal cause sorts out most of the factual causes that I have mentioned, and instead focuses on the inquiry that is relevant to according responsibility for the fire: the person who dropped the match into the wastepaper basket.

\section{Returning to Define Causation}

Causation is, thus, the combination of the two inquiries that I include under the headings of factual and legal causation. The precise nomenclature of those headings is heavily debated in the literature, and the separation of the headings is ignored in the jurisprudence, but a middling, basic definition of the causal inquiry would accord to these two questions. It is, obviously, necessary to satisfy both factual and legal causation for causation to be 'satisfied'.

\section{Effects}

This definition heading is one that is, perhaps surprisingly, very little understood. ${ }^{27} \mathrm{It}$ would not be over-bold to state that judges and legal academics are not generally trained in statistics, epidemiology, or medicine. ${ }^{28}$ Causality is a significant field in these disciplines as well: and these disciplines have some significant, but easily missed, insights. The most significant insight that requires definition here is the difference between effects of causes (EoC)

\footnotetext{
${ }^{26}$ Stapleton, Jane, supra note 22 at 17.

${ }^{27}$ Alexander Philip Dawid, "Statistical Evidence for Causality" in Perspectives on Causation (Oxford: Hart, 2011) 134. The majority of this section is drawn from this insightful chapter. All references are to this work, unless otherwise stated.

28 As Stapleton notes in her strong criticism of the Judges' approach to scientific evidence in Sienkiewicz Stapleton, Jane, supra note 5.
} 
and causes of effects (CoE). The significant difference between the two terms, despite the confusingly similar nomenclature, requires at least cursory definition.

\section{Effects of Causes (EoC)}

Effects of causes are general questions. They focus on a prospective inquiry: they ask "Does A cause B". ${ }^{29}$ Dawid's example of such a question is: "I have a headache. I am wondering whether to take aspirin. Will that cause my headache to disappear?" 30

\section{Causes of Effects (CoE)}

In contrast, causes of effects are individualized, purposive inquiries. ${ }^{31}$ They look retrospectively. A Cause of Effect question would follow this bound: "I have taken an aspirin, and my headache from several hours ago has disappeared. Did taking the aspirin cause my headache to disappear". ${ }^{32}$

\section{The Difference Between EoC \& CoE}

Scientific inquiries are largely concerned with EoC inquiries. Science has the active role in ascertaining how inventions work; if a food additive is safe; if a device can function in a particular way; and any number of other inquiries. ${ }^{33}$ Science largely looks forward to determine whether a cause now will result in a particular effect later.

Legal inquiries are largely concerned with EoC inquiries. Legal inquiries, and in particular, corrective justice derived causal inquiries, are retrospective: they look to specific instantiations of events. ${ }^{34}$ These inquiries want to know what the effect of cause was in the

\footnotetext{
29 Dawid, supra note 27 at 134.

${ }^{30}$ Ibid at 137.

31 Dawid, supra note 27.

32 Ibid at 137.

33 See, for eg Richard Goldberg, "Epidemiological Uncertainty, Causation, and Drug Product Liability" (2014) 59 McGill Law Journal 777.

34 Stapleton, supra note 23 at 437.
} 
past. To refer again to the flaming paper allegory, legal inquiries undertake a contrastive $\mathrm{CoE}$ inquiry. The legal causal inquiry contrasts the effects of the different causes, and seeks some finding as to isolating one. The effect of the oxygen cause of the fire is one that the law is not relevantly concerned with. Nor is the effect of the cause of the falling match. The effect of the malfeasant dropping the match in the wastepaper basket is the cause that the law is concerned with: the law ascertains this by contrasting the effects of the varied causes, and, in so doing, excludes that which it does not wish to include.

It is exceedingly easy to confuse the EoC and $\mathrm{CoE}$ inquiries: not least because of their doppelganger nomenclature. Yet, in practice, the difference between the two is a potential chasm. If the court fixated on the EoC, then a court would not be able to find causation, leaving the owner of the ashen building without remedy. The court would not be able to find causation because the effects of the causes can never, in an ordinary court setting, be proven. Courts are not scientific tribunals: the vagaries of physics are not provable in a court. ${ }^{35}$ However, CoE is provable. By using the contrastive mechanism, courts can determine that cause of a particular effect, in contrast to the cause of another effect, is relevant. The constant cause of the effect of the constant presence of gravity, oxygen and paper can be contrasted with the non-constant cause of the effect of a malfeasant dropping a lit match into the basket. Only then can causation in its current sense be made out. It is when courts, and commentators, mistake EoC for CoE that their inquiries stumble. ${ }^{36}$ In material contribution to risk inquiries, understanding the difference between the two is exceedingly important for those writing, and thinking on causation. The difference between EoC and CoE is highly valuable to bear in mind throughout any considerations of this thesis, and writings on cause in general.

35 Mozersky v Cushman, [1997] No 4912 OJ (Ontario General Division) at 66.

36 See Stapleton, Jane, supra note 5. 


\section{E Summary: Essences of Cause}

This section has defined the concepts that need understanding for the rest of this thesis to be comprehensible. These concepts are what, in education parlance, are referred to as 'threshold concepts'. ${ }^{37}$ This section was aimed in catapulting the reader beyond miscomprehension of the confused concepts of causation, legal causation, factual causation, and the difference between causes of effects and effects of causes. These concepts have inherent and essential importance to the remainder of this thesis; I could not, in good conscience, move forward without providing my firm structure to these sometimes variable concepts.

${ }^{37}$ Jan H F Meyer \& Ray Land, "Threshold concepts and troublesome knowledge” (2005) 49:3 Higher Education 373 at 375 . 


\section{Disentangling the Gordian Knot: Parsing the Theoretical Threads of}

\section{THE LAW OF NEGLIGENCE}

- "Every institute and principle of law has a philosophy—as every object in the sun has its attendant inseparable shadow" 38

This section stands as an oblique literature review of tort law theory. In lieu of a pastiche of the polyglot theories of tort law, this section justifies what goals I seek to maximize. There are expansive, and legitimate, quandaries regarding the purpose of tort law, and what goals an ideal, or improved, system would seek to maximize. This section does not attempt to definitively resolve this debate: to do so would be a task for Ronald Dworkin's hypothetical Judge Hercules, ${ }^{39}$ not this modest thesis. Instead, this section seeks to make a reasonable assertion about the goals of tort law. By doing so, the latter, substantive sections of this thesis can elaborate upon how to maximize these goals in the specific area of unorthodox causation.

It seems somewhat paradoxical to start a thesis that is avowedly pragmatic with a tranche of theoretical analysis. The standard approach for a pragmatist would be to state, simply, what their starting point was, and then get to the substance of the matter: the analysis of history and concepts. Yet, for this thesis, at least, following this approach would be an error. The current authoritative statement on material contribution to risk-Clements $v$ Clements $^{40}$ — prioritizes what I call the 'why'. Rather than focusing on the 'how' of varying causal tests in response to complex circumstances, the Court in Clements instead emphasized the why imperative of doing so. I term this the 'why'. The core of this 'why' is the purpose of

\footnotetext{
38 John Henry Wigmore, Select Cases on the Law of Torts (Boston: Little, Brown and Company, 1912) at vii.

39 Ronald Dworkin, Law's Empire (Cambridge: Harvard University Press, 1986) at 225.

40 Clements v Clements, supra note 1.
} 
the causal inquiry in negligence itself. This 'why' is—admittedly imperfectly—captured in one theory or another. This following section will find the 'why' for the causal process.

This section will develop my thesis of how to improve causation by stating a methodology for what is important to tort law. ${ }^{41}$ Only by noting what elements are important to maximize, is it possible quantify a non-abstract improvement. ${ }^{42}$ The following section is structured as a triptych of corollaries. Firstly, it finds a highly general goal of law. Secondly, with more specificity, it enunciates this goal within tort law itself. Thirdly, and finally, it looks to causation itself, and aims to see if causation pursues the same, or different, goals to its parent concepts. By doing so, this section provides a clear methodology for the latter sections of this thesis to improve, on stated grounds, the function of material contribution to risk in Canada.

\section{A At The Top of The Inverted Pyramid: Finding A Purpose For Law}

To ask why there is law is a necessary, interlocutory step. ${ }^{43}$ With the emphasis on the corollary, but often passionate debates over what is law, ${ }^{44}$ it is easy to forget that it is nonetheless important to ask why we have law itself. All of the corollary questions regarding why we have tort law; why we have causation; and why we have material contribution to risk, are each premised on a bounding of the purpose of law at this, early, stage. There is an endless variety of theories outlaying exactly why we have law, and, at the highest of

\footnotetext{
${ }^{41}$ Brian Leiter, "Beyond The Hart-Dworkin Debate: The Methodology Problem in Jurisprudence" (2003) 48 American Journal of Jurisprudence 17 at 27-31.

42 John Finnis, Natural Law and Natural Rights, 2nd ed (Oxford: Oxford University Press, 2011) at 6, 7-12.

${ }^{43}$ Robert Marsh, "What is Law?" in Anthony Walsh \& Craig Hemmens, eds, From Law to Order: The Theory And Practice of Law and Justice (Lanham: American Correctional Association) 1 at 3.

${ }^{44}$ See, for example, one of the defining debates of $20^{\text {th }}$ century legal theory, focusing on the separation between law and morality, in: H L A Hart, "Positivism and the Separation of Law and Morals" (1958) 71:4 Harvard Law Review 593; HLA Hart, The Concept of Law, 2nd ed (New Haven: Yale University Press, 1994); Robert G Bone, "Lon Fuller's Theory of Adjudication and the False Dichotomy Between Dispute Resolution and Public Law Models of Litigation" (1995) 75 BuL REv 1273; Lon Fuller, The Morality of Law, Revised Ed ed (New Haven: Yale University Press, 1964).
} 
abstractions, why law is a normatively desirable thing to have. ${ }^{45}$ Before any of the addendum analyses are undertaken, it is important to note and recognize the goals of law itself.

A broad cross-section of theorists have attempted to divine a general purpose for law. Plato made the first substantial contribution to considering why we have law. In Minos, Plato's Socrates explained "the law wishes to be nothing less than the discovery of what is". Moving forward two millennia Austin conceived of law, and the purpose, of law, as something to command and sanction the behavior of individuals, in order to preclude pernicious vagaries of human nature. ${ }^{47}$ These two early considerations symbolize the early contributions: both were visionary, but fundamentally incomplete. The proto-attempts to divine the purpose of law painted their answers in such a broad brush, that it smudges.

In a more contemporary setting, HLA Hart had a better conception of the general purpose of law itself. Hart conceived law as an agent of "social control" 48 which mandated and controlled what he termed "social conduct"49 via general rules. Hart, like much of the legal academy, did not have an epistemology, or even a methodology to quantify his terms and goals. ${ }^{50}$ Without a more accurate justification for what constitutes social conduct and social control, in a contemporary setting, it seems difficult to adhere to Hart's base proposition. ${ }^{51}$ Hart's earliest ideological adversary, Lon Fuller, had what seems closer to a desirable conception of the general purpose of law, but Fuller's view still falls short of an

\footnotetext{
45 See Gerald Postema, "Positivism and the Separation of Realists from their Skepticism: Normative Guidance, The Rule of Law, and Legal Reasoning" in Peter Cane, ed, The Hart-Fuller Debate in the Twenty-First Century (Portland: Hart Publishing, 2010) 259.

${ }^{46}$ Lewis Bradley, "Plato's Minos" (2006) 60:1 The Review of Metaphysics 17 at 27; The Roots of Political Philosophy: Ten Forgotten Socratic Dialogues, translated by Thomas Pangle (Ithica: Cornell University Press, 1987) at 69-70.

${ }^{47}$ John Austin, The Province of Jurisprudence Determined (London: John Murray, 1832).

${ }^{48}$ Hart, supra note 44 at 124 . At p 124

${ }^{49}$ Hart, supra note 44.

${ }^{50}$ Leiter, supra note 41 at 35.

${ }^{51}$ Finnis, supra note 42 at 7 . With Hart's latter retreat to state that law need only operate upon legal officials, the view of law as exercising social control over those ignorant of its control seems a devastatingly circular, and strangely osmotic process.
} 
accurate view. Fuller viewed law's purpose as generating bounds within which citizens interacted in a productive and social manner. ${ }^{52}$ Fuller conceived of the boundaries of law as the outer of permissible societal conduct, and, as such, crafted trammeled paths for citizens in the direction of their individual, self-selected ends. ${ }^{53}$ The issue, as Hart riposted, was that Fuller's bounds, and the bounds of his conception of Natural Law, was rooted in a flawed view of the intersection of morality and law. ${ }^{54}$

My preferred analysis of the general purpose of law, is "the claim that law's fundamental mode of operating is through guidance of self-directing agents by norms". ${ }^{55}$ The high level of generality constructs a broader foundation for the construct of legal concepts to build up this introductory view. The terming the operation of law as the provision of guidance opens up the possibility that it can guide in any direction: not a trammeled path, as posited by Fuller. The remark that the agents are self-directing is well taken, and recognizes that the purpose of law is not to remove agency, but to guide it.

At the highest level of generality, and the beginning of the structure of a methodology for this thesis, I take Postema's perspective as my conceptual foundation. The law, for this thesis, is a guiding force to direct independent agents, by generating and promulgating norms.

\footnotetext{
52 Fuller, supra note 44 at 210.

${ }^{53}$ Ibid at 215.

${ }^{54}$ See especially Hart, supra note 44.

55 Postema, supra note 45 at 267.
} 


\section{B At the Middle of the Inverted Pyramid: Divining The Good and Goals of Negligence Law}

\section{Limiting The Ambit to the Law of Negligence Specifically, Not Tort Generally}

It is important at this juncture make both a concession and disclosure. In sketching my methodology for finding a purpose that should be maximized within material contribution to risk, it am deliberately skipping a step in the methodological chain of contingencies. It makes intuitive sense to follow this structure:

1. Find a purpose of law;

2. Divine a purpose of its subset, tort law;

3. Seek a purpose of tort's subset, the tort of negligence;

4. Undertake a closer examination of causation.

I deliberately skip the second step in this path: the step of finding a purpose of tort law generally. Due to the enormity and importance of the topic, much ink has been spilled on the subject discussed above: the general purpose of law. The generality of the question, and topic, have not deterred extensive authorship. ${ }^{56}$

The same cannot be said of the second point: finding a general purpose of tort law. Tort is an exceedingly broad church: "the diversity of the interests protected by tort law and the types of conduct sanctioned by it makes it unrealistic to generalize about the purposes of tort law". ${ }^{57}$ Izhak Englard recounts at least a dozen separate approaches that can be taken in divining an approach to find a foundation to tort law. ${ }^{58}$ When the American Bar Association

\footnotetext{
${ }^{56}$ John Gardner, "What is Tort Law For? Part 1. The Place of Corrective Justice" (2011) 30:1 Law and Philosophy 1; Leon Green, “Tort Law Public Law in Disguise I” (1959) 38 Tex L Rev 1; Leon Green, “Tort Law Public Law in Disguise: II” (1959) 38 Tex L Rev 257.

${ }^{57}$ Klar, supra note 11 at 9.

58 Izhak Englard, Corrective and Distributive Justice (Oxford: Oxford University Press, 2009) at 205. At 205.
} 
conceives of tort law not that "of one large tree, but a dense placed forest area", ${ }^{59}$ they paint a clear metaphor of an unceasingly wide area. I deliberately exclude analysis and discussion of the other areas of tort law. These other areas: the 'intentional torts' are so diverse that their analysis adds little; and takes much valued time and space. Seeking a unifying purpose for all of tort law is beyond the ambit of this thesis. To keep this work focused, I skip thepossibly impossible — step of divining a purpose for all of tort law; and trust that in doing so, I don't create a fatal flaw in crafting this methodology.

\section{Finding the Goals of Negligence}

The modern conception of the law of negligence can trace its origins back nearly four and a half centuries. ${ }^{60}$ Theoretical underpinnings can be traced back nearly two and a half millennia. ${ }^{61}$ Despite this weighty antiquity, negligence has been validly, and wittily, referred to as "unloved". ${ }^{62}$ Ripstein notes: "no other doctrinal area is both central to the curriculum and widely disdained". ${ }^{63}$ Perhaps due to this opprobrium, but more likely due the vagaries and complexities of the subject matter, there are only two complete dueling theories that attempt to account for the law of tort. ${ }^{64}$ This section outlines these theories, and concludes by interrogating these theories, and making a selection of which theory the remainder of the thesis views as the core of negligence law.

This section asks: what are the goals of the law of negligence? Answering this question is fundamental to creating a methodology for the remainder of this thesis. Only by

\footnotetext{
${ }^{59}$ Marshall Shapo \& American Bar Association, Towards A Jurisprudence of Injury: The Continuing Creation of Substantive Justice in American Tort Law (American Bar Association, 1984) at 2.

${ }^{60}$ Newis v Lark, [1571] 75 ER 609 stands as one of the earliest cases which closely resembles the modern conception of tort law.

${ }^{61}$ William Lucy, Philosophy of Private Law (New York: Oxford University Press, 2007) at 268.

"62 John Goldberg, "Unloved: Tort in the Modern Legal Academy" (2002) 55 Vanderbilt Law Review 1501. ${ }^{63}$ Ripstein, supra note 18 at 1.

${ }^{64}$ Although there are substantive criticisms from Feminism, Marxism, Critical Legal Studies, among other schools of thought, these schools have not attempted to create a complete theory of tort law, but instead critique errors within the existing framework: see, for eg: Joanne Conaghan, "Tort law and feminist critique" (2003) 56:1 Current Legal Problems 175.
} 
establishing the legitimate goals of tort law can an argument be made that any reform is merited. The latter sections of this thesis argue for reform: but they do so based upon the maximization of the goals of tort law posited and defended in this section.

\section{Competing Theories of the Law of Negligence}

Tort law has two substantive, and substantively competing, underpinning theories. Torts are an avowedly pragmatic field of law. As an area, it is intended to resolve a direct controversy regarding wrongs between two equal, private parties. It is intended to eschew theory: and, as a result, be bound more closely to legal principle than legal theory. Inevitably, however, legal principle is — generally_based on legal theory, and consequently finding the theoretical core of tort law is the only manner in which to find which goals tort law should ultimately achieve. These two competing theories fundamentally contest the core purpose of tort law. These two theories are the theory of corrective justice, and what I dub instrumentalist theories. ${ }^{65}$

Corrective justice was first mooted by Aristotle, ${ }^{66}$ but was consolidated in its contemporary form by Ripstein, Coleman, and Weinrib. ${ }^{67}$ Corrective justice has been, and remains to be, considered the most substantive elaboration of the goals and structure of tort law. ${ }^{68}$

Instrumentalist theories look less to the explicit interests of the two parties before the court, but look to the effect of judicial action on the system as a whole. They are

\footnotetext{
65 Inspiration for the term 'instrumentalist theories' as a pastiche of realism, economics in the law, et alwas originally derived from Gemma Turton, A critical analysis of the current approach of the courts and academics to the problem of evidential uncertainty in causation in tort law University of Birmingham, 2013) [unpublished].

66 Aristotle, Nicomachean Ethics (350AD).

${ }^{67}$ Most evocatively in: Ernest Weinrib, The Idea of Private Law (Cambridge, Massachusetts: Harvard University Press, 1995).

${ }^{68}$ See, for example: Gardner, supra note 56; Richard A Epstein, "Causation and corrective justice: a reply to two critics" (1979) The Journal of Legal Studies 477.
} 
avowedly pragmatic, and have had significant relevance to individual cases, ${ }^{69}$ and continue to have importance to entire legal systems, especially in the United States.

\section{(a) Corrective Justice}

Corrective justice is the current de facto theory underpinning the law of negligence. ${ }^{70}$ The fact that it is so is not, however, sufficient basis to take for granted the centrality of corrective justice. This sub-section will outlay the structure and justification for the concept of corrective justice in negligence law; but will not conceive it as the theory of negligence law unless the justifications are compelling.

\section{(i) Aristotle's Conception of Corrective Justice}

For the law of negligence, corrective justice is a monistic theory: it encapsulates all of negligence law. As averred to previously, corrective justice finds its oldest roots in Aristotle's' work Nicomachean Ethics. ${ }^{71}$ In Aristotle's life, corrective justice was merely a concept: it did not have a pluralist legal system in which to graft itself on to. Aristotle's conception was, for its age, revelatory. It conceived of a system in which parties were not simply accountable to the state for wrongdoing, but accountable to fellow citizens as well. Aristotle conceived a system in which two parties could obtain ison, which in ancient Greek constituted fairness and equality. ${ }^{72}$ External perspective, argued Aristotle, was not the domain of corrective justice: it added nothing but confusion. ${ }^{73}$ Aristotle was, however, operating significantly before his conceptions could be operate in a legal system, and thus have the frailties of his system of corrective justice brought to light. His view was one

\footnotetext{
69 Turton, supra note 65; Fairchild v Glenhaven Funeral Homes, [2002] 22 UKHL (House of Lords).

${ }^{70}$ See, for example, Jules Coleman, Risks and Wrongs (Cambridge: Cambridge University Press, 1992).

71 Aristotle: Nicomachean Ethics: Translation, Introduction and Commentary, translated by Sarah Broadie \& Christopher Rowe (Oxford: Oxford University Press, 2002) at 1129b20.

72 Weinrib, supra note 67 at 58.

73 Supra note 71 .
} 
"primarily concerned with structure rather than substance". ${ }^{74}$ At its core, Aristotle conceived the early framework of a system where two parties interacted to seek ison by righting a wrong by one party through compensation. ${ }^{75}$ His framework excluded formalist external morality, and instead was concerned with the fundamental immorality that existed between an unpunished wrongdoer and an un-compensated victim. This was, however, only a framework: the latter part of the $20^{\text {th }}$ century saw a significant expansion of thought in corrective justice, to the point where common law systems of negligence and corrective justice are either consanguineous or coterminous.

\section{(ii) The Modern Conception of Corrective Justice}

The forerunners of modern corrective justice, George Fletcher and Richard Epstein, only very lightly referred to the Aristotelian conception of corrective justice. ${ }^{76}$ They provided a slender from Aristotle to the current conception of corrective justice, insofar as they only tangentially linked their views of corrective justice to Aristotle. The work by these two modern authors has been appropriately described as "philosophically modest". ${ }^{77}$ The contemporary system of corrective justice, and the one that sits at the core of the common law system of negligence is best espoused by the generation after Fletcher and Epstein. George Coleman ${ }^{78}$ and Ernest Weinrib ${ }^{79}$ were responsible for the evolution of corrective justice to its most plausible conception.

\footnotetext{
74 Weinrib, supra note 67 at 57.

75 Supra note 71 at V.5 1133 b16.

${ }^{76}$ Epstein, supra note 68; Gary T Schwartz, "Mixed theories of tort law: affirming both deterrence and corrective justice" (1996) 75 Tex L Rev 1801 at 1803; George Fletcher, "Fairness and Utility in Tort Law Theory" (1972) 85 Harvard Law Review 537.

77 Schwartz, supra note 76.

78 Jules L Coleman, "Tort law and the demands of corrective justice” (1991) 67 Ind LJ 349.

79 Ernest Weinrib, "Corrective Justice" (1992) 77 Iowa L Rev 403; Weinrib, supra note 67.
} 
Coleman states that "corrective justice demands that wrongful (or unjust) gains and losses be rectified, eliminated, or annulled" ${ }^{80}$ He views the necessity and morality of this outcome as reflecting both the interest of wronged party, and the duty of the injuring party. He views these as corresponding views with which corrective justice, and the law of negligence, should fundamentally concern itself.

Weinrib states his conception of corrective justice most pithily when he states: "Corrective justice is the idea that liability rectifies the injustice inflicted on one person by one person on another". ${ }^{81}$ His emphasis here, and the emphasis of corrective justice, is that negligence is fundamentally bilateral. It responds in each instance to the demands of the two parties before it: its concerns are limited and strictly bounded by these two parties.

This conception can be contrasted with a multilateral, or unilateral conception. A multilateral conception is one where the concerns of not just the parties before the court, but all parties within the community are to be the concern of the court. Such a conception takes form in the concept of distributive justice: a kissing cousin of corrective justice, but not one that has found favor in Canadian, or most common law legal systems. This conception has taken form in the New Zealand Accident Compensation Scheme, ${ }^{82}$ and to an extent, the Australian Dust Diseases Tribunal. ${ }^{83}$ Both are novel antipodean approaches to the unique problems of causation; but each is so deeply different to the legal reality in Canada, I choose not to focus on them.

\footnotetext{
${ }^{80}$ Coleman, supra note 78 at 357.

${ }^{81}$ Ernest Weinrib, “Corrective Justice in a Nutshell” (2002) 52 University of Toronto Law Journal 349 at 349.

${ }^{82}$ For an overview of the New Zealand Accident Compensation scheme that has functionally displaced the law of negligence in New Zealand, see Geoffrey Palmer, "New Zealand's Accident Compensation Scheme: Twenty Years on" (1994) 44:3 The University of Toronto Law Journal 223 at 247.

${ }^{83}$ For an overview of how the Dust Diseases Tribunal Operates in one of the Australian jurisdictions, see John Lawrence O’Meally, “Asbestos Litigation in New South Wales” (2007) 15 JL \& Pol'y 1209.
} 
A unilateral conception would be one where the interests of one party exclusively, or perhaps one party dominantly, is the concern of a court. Such a system is seen nowhere in the developed world in negligence law.

As a bilateral system, corrective justice attempts to reach an outcome where the two parties before the court reach a just resolution of the alleged injustice. Corrective justice seeks to answer an "allocative moral question" 84 insofar as resources can be allocated between the parties. In the conception of the courts applying a system of corrective justice, the question is how to allocate rights and resources in order to resolve a moral issue. William Lucy, in an exercise of brevity being the soul of wit, perhaps unwittingly evinces this by structuring his book Philosophy of Private Law into two parts: Who Did What?; and Who Pays and Why? As Hanoch Sheinman pithily notes 'Corrective justice corrects: 85 and it does so almost exclusively by pecuniary compensation.

Negligence law and corrective justice have a mirroring foundational purpose: they both seek to allocate to an injured party that which they had but-for the wrongful injury. In the parlance of negligence, to do so 'restores' the injured party—as best as the law can — to the position they were in before the injury. In the parlance of corrective justice, to do so corrects the moral breach by one party before the court by paying penalty to morally correct themselves, ${ }^{86}$ and also practically correct the other party before the court.

Corrective justice is viewed as a heuristic that is internally moral because it seeksand, perhaps in ideal cases, obtains-historical equipoise between the parties. Corrective justice does not make a moral or ideological judgment of the parties: it regards them to be

\footnotetext{
${ }^{84}$ Gardner, supra note 56 at 6.

${ }^{85}$ Hanoch Sheinman, "Tort Law and Corrective Justice” (2003) 22:1 Law and Philosophy 21 at 24.

${ }^{86}$ See note 71. At V.1 1129b26, where Aristotle makes clear his view of corrective justice as the moral balancing to another person.
} 
equals before the court, even if the assets that the parties hold are unequal. ${ }^{87}$ Aristotle conceives of this as "rectificatory, operating in interactions between one person and another." ${ }^{88}$ This rectification is based on the "pre-transaction equality of the parties", ${ }^{89}$ and rectifies the current inequality by doing the court's best to restore the parties to the position before the wrong.

Essential to the form and structure of corrective justice is compensation. It is obviously not possible to resurrect a fatally injured plaintiff by court order, nor is it possible to un-crash a negligently manufactured car, or erase a trauma. The arsenal of remedies that negligence has is a function of the modern economic system: money is the fundamental fungible good, so much so that it displaces nearly all other remedies. ${ }^{90}$ Aristotle remarked that financial compensation "acts like a measure, making things commensurable". 91

\section{(iii) Summarizing Corrective Justice}

Corrective justice stands as the monistic theory of negligence law as it currently exists. In essence, it views the interests of the two parties before it as paramount. Corrective justice, and the corresponding legal system built around it, is aimed at correcting: ${ }^{92}$ it corrects the wrong by the wrongdoer by returning the plaintiff to the position that it would have been before the wrong.

\section{(b) Instrumentalist Theories}

Unlike corrective justice, instrumentalist theories are not monistic, but instead are pluralistic. Instrumentalist theories have radically different goals to corrective justice.

\footnotetext{
87 Weinrib, supra note 79 at 406.

${ }^{88}$ Supra note 71 at V.2 1130b30-1131a2.

89 Turton, supra note 65 at 14.

90 Steven P Croley \& Jon D Hanson, "The Nonpecuniary Costs of Accidents: Pain-and-Suffering Damages in Tort Law” (1995) 108:8 Harvard Law Review 1785 at 1790.

${ }^{91}$ Supra note 71. At V.5 1133b16.

92 Sheinman, supra note 85.
} 
Instrumentalism is generally considered to synonymous with a pragmatic approach. ${ }^{93}$ Despite significant popularity in the USA, instrumentalism is not considered by most to be at the core of conceptions of the common law view of negligence. ${ }^{94}$ Like corrective justice, instrumentalism has a concerted, and broad theory of negligence. This theory covers all of negligence, and has, at its core, clearly enunciated goals that instrumentalism aims to maximize. There are many different forms of instrumentalism, ${ }^{95}$ with forms everywhere on the plane from those that mirror the current structure of negligence law, to those that bear scarce resemblance. This section, for the sake of brevity, does deliberately does not delve deep into these vagaries, and instead charts a course for the middle: what is termed “moderate instrumentalism". 96 This clarity of purpose and enunciation makes instrumentalism a potentially compelling basis for negligence. The following sub-section outlines the evolution, structure, and purposes of instrumentalism.

\section{(i) Founding Conceptions of Instrumentalism}

Instrumentalism cannot trace its origins as far back as Aristotle, but it can trace its history to a figure nearly in the same pantheon of influence: Justice Oliver Wendell Holmes. His 1881 text, The Common Law. ${ }^{97}$ Justice Holmes' work, both as an academic and a jurist, shaped American jurisprudence like few others; and among these formations, was the thoroughly realist conception of instrumentalism. This early conception of instrumentalism was oriented towards the Realist school of legal theory. It viewed law not as an end unto itself, but instead, a tool to achieve specific outcomes. Law was intended to serve a function

93 Canadian Oxford Dictionary, 2nd ed.

94 Palmer, supra note 82. Although, it could perhaps be fairly stated that New Zealand's Compulsory Accident Compensation Scheme displays both instrumentalist and distributive justice goals.

95 See, for example S. Green, supra note 13; Leon Green, supra note 56; Calabresi, supra note 19; Steven Shavell, Economic Analysis of Accident Law (Cambridge: Harvard University Press, 1987).

96 Ripstein, supra note 18 at 4.

${ }^{97}$ Oliver Wendell Holmes Jnr, The Common Law (Boston: Little, Brown and Company, 1881). 
of democratic desires, and was turned towards, and attuned to, that end. To echo the pithy Scheinman extract in an earlier paragraph, instrumentalism is an instrument. To what end the instrument was turned was the right of the populace, and the responsibility of the judge. To turn full circle, instrumentalists replicated Rudolf Von Ihering's conception of "law as a mean to accepted ends": ${ }^{8}$ the ends to which law was to be turned was a broad selection of, potentially disparate goals.

This early conception of instrumentalism was not formulated exclusively with tort law in mind, but instead formed as a reaction to the perceived formalism of jurisprudence at the time. The more modern instrumentalist conception relevant to tort law did not take meaningful shape until the middle of the $20^{\text {th }}$ century.

\section{(ii) Instrumentalism as it Concerns the Law of Negligence}

Instrumentalism took an obtuse path to significance in the law of negligence. As a generalist theory, instrumentalism did not have negligence law as its central concern. It had a systemic perspective: but in the section of the system where negligence resides, instrumentalism had a meaningful structure and purpose.

Instrumentalism viewed the law of negligence within the broader scaffold of law. ${ }^{99}$ The law of negligence, the broader law of tort, the law of contract, and the law of property are generally considered to form what is termed 'private law'. As a theory, instrumentalism marginalizes the first word of that phrase. As a structure, private law is private insofar as the parties involved are not public parties: they are, as corporeal figures, a plaintiff and defendant. Instrumentalism maintains the private-ness, and the bilateral nature of corrective

\footnotetext{
98 Robert S Summers, "Pragmatic Instrumentalism in Twentieth Century American Legal Thought-A Synthesis and Critique of Our Dominant General Theory About Law and Its Use” (1980) 66 Cornell L Rev 861 at 869. 99 Turton, supra note 65 at 9.
} 
justice only this far, however. ${ }^{100}$ The interaction between these two parties is not an

exclusively private one, even if, structurally, they are the only two parties before a court in a negligence action. Instrumentalism regards a litigated instance of negligence as a circumstance in which to potentially redress broader issues within a liberal society.

Instrumentalism sees no problem with altering the structure of tort law from something exclusively private, to something with a broader ambit. Ripstein neatly sums up this thread of instrumentalism, by noting its view that:

the fact that something is originally or ideally suited to one purpose does not stop sensible people from using it for other purposes for which it might also be effective. Chairs may really be for sitting on, and any other uses of them derivative, but when you are faced with an approaching lion, you use whatever happens to be available. ${ }^{101}$

The modern instrumentalist conception of negligence places at its center the concept of efficiency. ${ }^{102}$ Reaching an efficient outcome is a central virtue and aspiration. ${ }^{103}$ Moving from the realist and proto-instrumentalist views of Holmes, the modern conception of instrumentalism in negligence law deals with the efficient minimization of risk: ${ }^{104}$ it is, effectively, a forward looking, harm avoidance mechanism. ${ }^{105}$ Calabresi viewed negligence law as a system to minimize both the costs of accidents for plaintiffs, and the costs of avoiding accidents for defendants. ${ }^{106}$ This view in instrumentalist accounts is a pervasive

\footnotetext{
100 Lucy, supra note 61 at 35.

101 Ripstein, supra note 18. At 4.

102 Calabresi, supra note 19.

103 Steven Shavell, "Strict liability versus negligence" (1980) The Journal of Legal Studies 1; Steven Shavell, supra note 95.

104 S. Green, supra note 13 at 161.

105 As compared to the backwards looking harm correction mechanism: see, for example: Weinrib, supra note 79.

106 Calabresi, supra note 19 at 26-28.
} 
one. $^{107}$

The instrumentalist conceptions of negligence law are thus unilateral. The structure is bilateral: two parties litigate to pursue sought ends. But, however, the ends sought by the instrumentalist system of negligence diverge from that of the parties, and seek to apply $e x$ ante considerations to reflect, and improve society as a whole. The concerns of the parties are important, but the concerns of society are sublimate these concerns.

\section{(iii) Summarizing Instrumentalism in Tort Law}

The neatest summary of instrumentalism is achieved by looking at its direction. Instrumentalism does not look exclusively backwards to the parties; but instead looks forward. In so doing, it looks to what parts of liberal society can be improved by choosing one outcome over another. The structure of instrumentalism is unchanged from the corrective justice accounts: within a court system, two parties — the plaintiff and defendantlitigate to pursue particular ends. The purpose of instrumentalism is, however, a significantly different one. It certainly seeks to reach a just reconciling of the conflict between the parties: but within that purpose justice are far wider goals. ${ }^{108}$ Each decision seeks to correspond to what seems just in a liberal society, not what seems just between the parties. ${ }^{109}$ Each judicial adjudication on negligence is intended to regard, and further the goals of this society. This regard makes the purpose of instrumentalism a subset of state activity: the purpose of instrumentalism in negligence law is to further state goals, whatever they may be.

\footnotetext{
${ }^{107}$ Lucy, supra note 61 at 39; William Lucy, "Method and Fit: Two Problems for Contemporary Philosophies of Tort Law" (2007) 52 McGill LJ 605.

${ }^{108}$ Leon Green, supra note 56.

109 Ripstein, supra note 18 at 7.
} 


\section{Choosing and Defending a Theory of Negligence: Corrective Justice or \\ Instrumentalism?}

This section makes a choice that provides a direction for the remainder of the thesis. It selects and defends a choice of theory. This theory gives animus and purpose for the arguments in the remainder of this thesis. The immediately preceding section outlaid, in a necessary brief fashion, the core of the two competing accounts of the law of negligence: corrective justice, and instrumentalist theory. This following section provides clear justification for the use of corrective justice as the core of this thesis, partly by noting the strengths of corrective justice, and partly by noting deficiencies with the instrumentalist accounts of negligence law.

\section{(a) Selection Criteria}

In order to make a methodologically sound selection of theory, there must be meaningful criteria by which this selection is made. ${ }^{110}$ Stephen Smith, in his book Contract Theory ${ }^{111}$ enunciates four criteria for coherence between theory and discipline: ${ }^{112}$

1. Fit

2. Coherence

3. Morality

4. Transparency

Emma Turton, in using the same criteria for her interrogation of theoretical backing for the broader area of tort law, speaks persuasively to the strength of these four criteria. ${ }^{113}$ Her

\footnotetext{
110 Andrew Robertson, "Rights, Pluralism and the Duty of Care" in Donal Nolan \& Andrew Robertson, eds, Rights and Private Law (Portland: Hart Publishing, 2011) 436.

${ }_{111}$ Stephen Smith, Contract Theory, 1st ed (Oxford: Clarendon Press, 1993).

112 Ibid at 7.

113 Turton, supra note 65. At 8. Indeed, I found her views in this area highly persuasive, but did not strictly accord my views with her perspectives on a heavy weighting towards coherence at the expense of the other three criteria.
} 
reference to Andrew Robertson's characterisation of Smith's criteria as an “orthodox and widely followed approach to legal analysis" ${ }^{\prime 14}$ is particularly well taken. Robertson's elaboration of these four criteria usefully puts muscle on the rather skeletal limbs of these four criteria:

\begin{abstract}
Those four limbs are: fit (the extent to which the theory is consistent with the outcomes of cases and possibly also the accepted rules of the given body of law), coberence (the extent to which the theory reveals an intelligible order in the given body of law and allows it and related bodies of law to be understood as a unified system), transparency (the extent to which the theory is consistent with the explanation given by lawmakers, which in the case of interpreting the common law means the explanations given by judges in the cases), and morality ('how the law might be thought to be justified even if it is not justified'). ${ }^{115}$

Turning to fit, coherence, transparency and morality one by one provides a methodologically sound basis for preferring corrective justice as the nexus for
\end{abstract} negligence.

\title{
(i) Fit
}

The divergence between corrective justice and instrumentalism is not strongly marked in the context of the criteria of 'fit'. Both corrective justice and instrumentalism structurally operate as bilateral systems: they both maintain having two parties—plaintiff and defendant - as the agents in the system. The outcomes in cases broadly reflect the bilateral structure of cases before it: courts consider both the concept of compensating an injured plaintiff, and penalizing a culpable defendant. Yet, instrumentalism does fail in a fit with the internal view of law. ${ }^{116}$ Judges do, at times, refer to using the law as an instrument to further

\footnotetext{
114 Robertson, supra note 110 at 438. At 438.

115 Ibid at 437 referring to; Smith, supra note 111.

116 Joseph Raz, "Formalism and the Rule of Law" in Robert George, ed, Natural Law Theory (Oxford: Clarendon Press, 1992) 309.
} 
societal values. ${ }^{117}$ Yet, in the vast majority of cases, the internal view of the judicial decision makers fits most closely with the far narrower conception of corrective justice: judges look to correct a previously inflicted harm by the defendant. ${ }^{118}$ Only in the cases, to use a conceptually gauche term, that are in the penumbra, ${ }^{119}$ does instrumentalism fit: but these cases are clearly in the minority. To use the exceptional cases, like Fairchild, ${ }^{120}$ to justify that instrumentalism met the fit criteria would be, literally, allowing the exception to subsume the rule. It would be the tail wagging the dog. The rule, or norm, is the accepted internal view that the court looks to, and only to, the position of the parties before the court, and aims to restore the plaintiff to the position they would have been in, but for the negligence of the defendant. ${ }^{121}$ Smith's concept of 'fit', ${ }^{122}$ and Robertson's elaboration of it, ${ }^{123}$ favours corrective justice as the core of negligence law.

\section{(ii) Coherence}

Corrective justice also beats out instrumentalism as a coherent order for negligence law. Corrective justice conceives of negligence law as a subset of private law. As such, it is intended to respond to private interests: namely those of private parties before it. Negligence is an adjudication of the private interests before it: and corrective justice emphasizes the 'private' element of this. Weinrib compellingly asserts that we must treat "private law as an internally intelligible phenomenon by drawing on what is salient in juristic experience, and by trying to make sense of legal thinking and discourse in their own terms". ${ }^{124}$ Negligence law is an area to resolve contests over private interests. Public law, on the other hand, has a rather

\footnotetext{
117 See especially Lord Hoffman's judgment in: Fairchild v Glenhaven Funeral Homes, supra note 69.

118 See especially Snell v Farrell, supra note 7; Clements v Clements, supra note 1.

119 Hart, supra note 44.

120 Fairchild v Glenhaven Funeral Homes, supra note 69.

121 Livingstone v Rawards Coal Co, [1888] 5 App Ca 25.

122 Smith, supra note 111.

123 Robertson, supra note 110.

124 Weinrib, supra note 67 at 2-3.
} 
wider purview: to resolve disputes that pertain to the public at large. Weinrib insists, and it seems the more intelligible view, that the law of negligence can, and should be intelligible on its own terms: as a system of resolving private contestations of rights and interests. To take the instrumentalist approach, and to view negligence using external terms such like efficiency and other ex ante considerations, is to erode to niche that negligence law holds. To do so leaves the position of the law of negligence fatally indeterminate, and certainly not intelligible or unified if it is to be understood using external, foreign conceptions.

When early instrumentalist Leon Green argues that tort is "public law in disguise", ${ }^{125}$ he dislocates negligence from an intelligible position within the broader structure of law, and places it within the public law sphere. Even without the obvious confusion of a central part of private law being labeled disguised private law, Green's view is not intelligible to those who operate within the structure: practitioners of law themselves. ${ }^{126}$

Allan Beever's typology of coherence finds two kinds of coherence: strong coherence, where the law can be viewed as unified system; and weak coherence, where at a minimum, the law should not be contradictory. ${ }^{127}$ Corrective justice scores highly on the view of negligence as an atomistic part of a unified system that corresponds to Postema's ${ }^{128}$ definition of law; and also certainly corresponds to the weak coherence view of noncontradiction.

Instrumentalism, does not score so highly on either strong, or weak coherence. The instrumentalist view of law, and of negligence, fails to cohere around any one, or any series of points, other than a responsiveness to the needs of a liberal society. ${ }^{129}$ On weak

\footnotetext{
125 Leon Green, supra note 56; Leon Green, supra note 56.

126 Weinrib, supra note 67. At 9.

127 Allan Beever, Rediscovering the Law of Negligence (Oxford: Hart Publishing, 2007) at 22-25.

128 Postema, supra note 45 at 267.

${ }^{129}$ Ripstein, supra note 18 at 7.
} 
coherence, instrumentalism is also weak. Aside from the category error of negligence as an area of private law being contradictorily dubbed public law, instrumentalism acknowledges and accepts contradiction at higher level than corrective justice. Negligence law contains interlocking, but independent parts: duty of care, breach, causation, and so on. The pluralism of instrumentalism can readily accept a contradictory public good in the duty of $\operatorname{care}^{130}$ and causation $^{131}$ parts of negligence. These contradictory perspectives remain acceptable to the pluralistic instrumentalism, but appear anathemic to Beever's, Robertson's, and Smith's conception of coherence. ${ }^{132}$

On the criteria of coherence, corrective justice once more enunciates the more persuasive view.

\section{(iii) Transparency}

Corrective justice seems to accord more clearly with Smith's conception of the criteria of transparency. Especially in Canada, corrective justice is the clear underpinning of negligence law. Robertson's elaboration of transparency as “the extent to which the theory is consistent with the explanation given by lawmakers"133 emphasizes what the internal view of the judiciary. It is fairly clear the judiciary views corrective justice as being consistent with their perspective of law. In Clements (Litigation Guardian of) v Clements, ${ }^{134}$ the Court referred closely to Weinrib's concept of corrective justice. ${ }^{135}$ The Court even summed up their view of the tort of negligence thusly: "if the defendant breaches this duty, and thereby causes injury to the plaintiff, the law "corrects" the deficiency in the relationship by requiring the

\footnotetext{
${ }^{130}$ For example, a conception of duty of care that would prioritize minimizing future accidents through maximising the cost of litigation through broad duty classes. See, for example, Robertson, supra note 110. ${ }^{131}$ For example, Sarah Green's conception of causation as an efficient mechanism wherein plaintiffs only receive partial compensation for injury: see S. Green, supra note 13.

132 Allan Beever, supra note 127; Robertson, supra note 110; Smith, supra note 111.

133 Robertson, supra note 110. It's worth noting that Robertson limits lawmakers to the judiciary in this criteria.

134 Clements $v$ Clements, supra note 1, paras 7, 13, 19.

135 Ibid, para 7 referring to; Weinrib, supra note 67 at 156.
} 
defendant to compensate the plaintiff for the injury suffered". ${ }^{136}$ This view is functionally identical to Weinrib's summation ${ }^{137}$ of the original Aristotelian conception ${ }^{138}$ of corrective justice.

In Whiten v Pilot Insurance $\mathrm{Co}^{139}$, the Court was clear in explaining their rejection of instrumentalist explanations of economics in negligence law. There, the Court emphasized that the law of negligence is fundamentally bilateral:

The concern to control recovery through the concepts of proximity and foreseeability signals the importance of this key principle that tort law is not grounded in responsibility at large to society or to indeterminate classes of plaintiffs, but on obligations to compensate adequately victims standing in a close enough relationship with a tortfeasor ${ }^{140}$

The Court was being clear in showing that negligence law is not concerned with instrumentalist concerns of efficiency, economic distribution, or externalities. Instead, the bounds of the law of negligence are conceived as narrow, expanding no further than the interests of the plaintiff and defendant before the court.

The criteria of transparency for the law of negligence most clearly accords with the theory of corrective justice. The Supreme Court of Canada had clear that they both regard corrective justice as the chrysalis for negligence; ${ }^{141}$ and that they reject instrumentalist conceptions. ${ }^{142}$

136 Clements v Clements, supra note 1, para 7.

137 See: Weinrib, supra note 81.

138 Aristotle, supra note 66.

139 Whiten v Pilot Insurance Co, [2002] 1 SCR 595.

140 Ibid.

141 Clements v Clements, supra note 1.

142 Whiten v Pilot Insurance Co, supra note 139. 


\section{(iv) Morality}

It is difficult to enunciate whether instrumentalism or corrective justice better satisfies Smith's criteria of morality. Robertson's characterisation of morality as "how the law might be thought to be justified even if it's not justified"143 is, on further probing, more demonstrative than the simple label of 'morality' would imply. To contrast this summation of morality from Robertson's rather similar enunciation of transparency, it is important to emphasize the latter part of that extract: "even if it's not justified". ${ }^{144}$ Robertson is alluding to what I refer to as occluded decision making: where courts seek a particular outcome first, and then—either clearly, or deliberately obtusely—reason backwards to reach that conclusion. The factors that determine this specious reasoning process are what Robertson avers to in this conception of morality

An account of instrumentalism in the law of negligence would have to place the goal of efficiency as the central aspiration. ${ }^{145}$ Posner, who advocated for an economic view of the law that is at times indistinguishable from instrumentalism, ${ }^{146}$ viewed law as "a means to bring about an efficient (in the sense of wealth-maximizing) allocation of resources by correcting externalities in the market's allocation of resources". ${ }^{147}$ Instrumentalists do not view negligence, or tort law, as atomistic parts of the legal system. The instrumentalist purpose of law, the effective original position, is a different one than that which I chose as the general purpose of law. ${ }^{148}$ As such, the law of negligence is subordinate to this broader conception of law.

\footnotetext{
143 Robertson, supra note 110.

144 Ibid.

${ }^{145}$ Calabresi, supra note 19; William Landes \& Richard Posner, The Economic Structure of Tort law (Boston: Harvard University Press, 1987); Richard A Posner, "The concept of corrective justice in recent theories of tort law" (1981) The Journal of Legal Studies 187.

146 See Landes \& Posner, supra note 145.

147 Posner, supra note 145 at 201.

148 Postema, supra note 45.
} 
One of the fundamental areas that may accord with Robertson's expansion on morality is the area enlivened by the 'deep pockets ${ }^{149}$ view. This perspective asserts that courts make an instrumentalist market allocation of resources in cases where a wronged impecunious plaintiff pursues a 'deep pocket' defendant: namely, one with significant financial capital. The widely held belief is that courts look beyond the details of the alleged wrong by the defendant, and instead to look at the positions of the parties in a more global sense. In so doing, the view is that courts make an allocative decision that inherently favours the weaker defendant.

The belief that courts do so, but occlude their reasoning on the grounds of propriety, is so widely held that it is almost a truism. To find in truth that there is indeed a deep pockets bias would go a significant way to finding that an instrumentalist view underpins "how the law might be thought to be justified even if it's not justified". 150

Despite the widely held assumption, it is unlikely that a deep pocket bias exists. Certainly, no evidence exists to support it. Courts do not justify, either explicitly, or in occluded reasoning, that a defendant with deep pockets should be considered differently in order to put into place instrumentalist externalities such as market reallocation. There is neither cognitive, ${ }^{151}$ nor real-world evidence ${ }^{152}$ of such an instrumentalist intersection in legal reasoning. Despite the intuitive feeling that, in deep pockets cases, courts are prejudiced against wealthy defendants simply because they can afford to pay out the damages award, evidentiary backing for courts acting such an instrumentalist fashion is thin. In T.G. $v$ Griffiths, the McLachlin, L'Heureux-Dube and Bastarache JJ bluntly opposed such a view,

${ }^{149}$ Robert J MacCoun, "Differential Treatment of Corporate Defendants by Juries: An Examination of the 'Deep-Pockets' Hypothesis" (1996) 30:1 Law \& Society Review 121; Neil Vidmar, "Empirical Evidence on the Deep Pockets Hypothesis: Jury Awards for Pain and Suffering in Medical Malpractice Cases" (1993) 43:2 Duke Law Journal 217.

${ }^{150}$ Robertson, supra note 110.

${ }^{151}$ MacCoun, supra note 149.

152 Vidmar, supra note 149. 
remarking "the goal of compensation is not simply a deep pockets rule". ${ }^{153}$ The Court followed up this pithy extract with a passing, but telling remark on the priorities of compensation: "our ultimate goal is a rule of vicarious liability that is fair to the plaintiff, the defendant, and society". ${ }^{154}$ The majority, consisting of Binnie, Cory, Iacobucci and Major JJ, listed their only policy considerations in a question of applying vicarious liability as compensation and deterrence: the very core goals of corrective justice, not instrumentalism. ${ }^{155}$

It seems likely that on the grounds of morality, corrective justice better satisfies the criteria of morality. Courts frequently aver to the corrective justice views of compensation and deterrence: two rationales that reflect the corrective justice bilaterally by focusing on the plaintiff and defendant, respectively. ${ }^{156}$ Courts do aver both explicitly and implicitly to policy in negligence cases: but this policy is not the instrumentalist conception of policy, but instead the corrective justice conception: namely the policy of plaintiff compensation and defendant deterrence. ${ }^{157}$ It seems clear that courts explicitly justify their morality to accord with corrective justice conceptions, and that instantiation of secret instrumentalist justifications are more puff than substance.

\section{(b) Choosing Corrective Justice as the Theory Of Negligence}

Corrective justice is the most coherent theory for the law of negligence in Canada. While instrumentalism certainly has some importance to so called hard cases, the central, common, and underlying theory of negligence in Canada is inexorably the theory of

\footnotetext{
$153 T(G) v$ Griffiths, 2 SCR 570 (1999), para 24.

154 T.(G.) v Griffiths, supra note 153.

155 Ibid, para 67.

156 Ward v Vancouver (City), [2010] 2 SCR 28, para 25; Bazley v Curry, [1999] 2 SCR 534, paras 34-36.

157 Bazley v Curry, supra note 156, para 34. At 34.
} 
corrective justice. Applying the four criteria of Smith, ${ }^{158}$ with helpful elucidation from

Robertson, ${ }^{159}$ corrective justice more organically satisfies each of these criteria. Each of these four criteria—namely fit, coherence, transparency, and morality sided with corrective justice; although fit was not entirely determinative.

Corrective justice is both the, and my, theory of the law of negligence. It is clear that Canada's system of negligence law is structured to support corrective justice: to make a useful contribution, this thesis does not challenge this structure, but instead aims to operate within this. To do so, the remainder of this thesis operates upon the internal, corrective justice view of negligence. The goals of law of negligence are coterminous with the goals of corrective justice. This thesis operates within the same bounds, and aims to maximize these goals.

\section{The Point of the Inverted Pyramid: Does Causation Have Separate, or the Same Goals as Negligence?}

The previous sections have looked at the general purpose of law, and the purpose of negligence. They have followed the shape of an inverted pyramid: starting at its widest in finding a purpose for law; narrowing to find the goals of negligence. This section is the narrowest, most pointed part of the inverted pyramid. It looks at what goals causation itself seeks to achieve. There has been much work on the broader goals of torts generally, and negligence specifically. ${ }^{160}$ There has, however, been relatively little work concerning the

\footnotetext{
158 Smith, supra note 111.

159 Robertson, supra note 110.

160 Arthur Ripstein \& Benjamin Zipursky, "Corrective Justice in an Age of Mass Torts" in Philosophy and The Law of Torts (Cambridge, UK: Press Syndicate, 2001) 214; Allan Beever, supra note 127.
} 
purpose of causation itself. ${ }^{161}$ It has been well noted that causation the vital component of corrective justice in negligence. ${ }^{162}$ It is not entirely clear whether causation seeks its own, freestanding goals, or if it seeks to maximize the goals of forebear, the broader concept of the law of negligence-and its theoretical antecedent, corrective justice. This section will look more closely at causation, and find whether it seeks only to maximize the corrective justice goals of negligence, or if it seeks something else entirely.

The broader purpose of causation is not extensively thought upon. The specific operation of causation has caused more consternation than most, but the abstract theoretical purpose of causation has attracted relatively sparse scholarship. ${ }^{163}$

Is the purpose of causation simply to make negligence a coherent concept? Or is the purpose an independent one, with broader goals insuperably wedded to the fabric of causation? This section looks to see what the purpose of causation is, and thus, what goals it seeks to bring about. The purpose of law has been subject to oceans of ink; the purpose of the law of negligence, rivers of ink; but the purpose of causation, only droplets. This thesis focuses on the law of causation: and deals with the superstructure of negligence, and its base, law, only insofar as is necessary. This thesis tries to maximize the goals of causation, negligence, and law, in that order. It is probable that causation follows the goals of negligence, and thus, corrective justice. But, with the core of this thesis squarely looking at how to maximize to goals of causation, it would be methodologically remiss not to consciously turn the mind to what these goals are. This section looks at whether causation pursues goals of a different character to the goals that the law of negligence pursues; and

\footnotetext{
${ }^{161}$ Despite the stellar work of Ernest Weinrib, among others. See, for eg: Weinrib, supra note 81; Weinrib, supra note 79; Weinrib, supra note 20; Weinrib, supra note 67; Ernest Weinrib, "The Special Morality of Tort Law" (1988) 34 McGill LJ 403.

162 Klar, supra note 11 at 445.

163 Jane Stapleton, "Legal Cause: Cause-in-Fact and the Scope of Liability for Consequences" (2001) 54 Vand L Rev 941 at 950 .
} 
ultimately finds that, although not servile, the goals of causation are the goals of the law of negligence. To put it bluntly: what work does causation actually do? This section attempts to answer this seemingly common-sense question. It bears reminding that, at this juncture, I do not delve deep in the differences between but-for causation and material contribution to risk, nor do I parse legal and factual causation. This section is tasked with understanding the purposes of the concept of causation, not its constituent parts and divergent interpretations.

\section{Importance of Causation to Negligence}

Causation is a, and perhaps the, cornerstone of the law of negligence. ${ }^{164}$ While duty of care can be seen as the organizing concept, causation is the core of negligence. Causation reflects the core of an underlying moral liability in the law of negligence. ${ }^{165}$ Causation is "essential to corrective justice". ${ }^{166}$ The structure of tort law is, to belabor a point, bilateral. It concerns the two parties before it: the plaintiff, and the defendant. Without causation, the law of negligence would involve the twin solitudes of the plaintiff and defendant. Looking at the duty of care would, in solitude, analyze to whom the defendant owed a duty. Examining a breach of this duty would similarly be atomistic in its purview. Examining harm suffered by the plaintiff would be an isolated occurrence. Only with causation can there be linkage between the defendant's duty, the defendant's breach, and the plaintiff's harm. Without causation, negligence would not, and could not have meaning. Corrective justice could not be formulated without some relation between wrongdoer and sufferer. Put simply, causation is the link that allows negligence to be bilateral. No case in negligence can be made without a

\footnotetext{
164 Lucy, supra note 61 at 145.

165 Michael S Moore, Causation and Responsibility: An Essay in Law, Morals, and Metaphysics (OUP Oxford, 2010) at 3.

166 Turton, supra note 65 at 61.
} 
proven causal link, and, issues with what constitutes 'proven"167 aside, no judge has argued otherwise. ${ }^{168}$ Tony Honore stated that "to insist on a causal connection... ensures that we impose liability only on those who, by intervening in the world, have changed the course of events for the worse." ${ }^{\text {169 }}$ Causation thus has the exclusive, and vital role of ensuring that negligence serves to intervene to minimize events that change the world for the worse. Causation has significant importance to the law of negligence. The following paragraph will inquire if this importance is so significant it permits causation to develop its own exigencies, and thus its own goals beyond those of negligence, and thus beyond those of corrective justice.

\section{Limited Role of Causation in Negligence}

Causation is a vital part of the law of negligence: but it is not an independent one. The role of causation is a more precise one than is generally assumed; and the purposes of causation are more targeted than would be imagined. What is vital at this juncture is less to outline what causation is, and rather to show what causation is not. In establishing whether the goals of causation are inside or outside the goals of negligence, it is necessary to establish the boundaries of causation. Only by asking what causation is not, is an outer perimeter for causation possible.

\footnotetext{
${ }^{167}$ Russell Brown, “The Possibility of 'Inference Causation': Inferring Cause-in-Fact and the Nature of Legal Fact Finding" (2010) 55 McGill Law Journal 1.

168 Benjamin C Zipursky, "Rights, wrongs, and recourse in the law of torts" (1998) 51 Vand L Rev 1. Although, some theorists have argued on behalf of incorporating a systems more closely penalizing wrongdoing, rather than cause.

169 Tony Honore, Responsibility and Fault (Oxford: Hart Publishing, 2009) at 120.
} 


\section{(a) Causation is a Guard Against, Not an Agent of, Independent Morality}

What causation is not is a method of conjoining morality and law in vexing situations. The law generates an exceedingly wide array of so-called "hard cases". ${ }^{170}$ In these cases, there is often a defendant who is, to some extent or another, a wrongdoer; and a plaintiff, who is, to some extent or another, a victim. It seems fundamentally problematic in these hard cases to reconcile a finding of non-liability with anything resembling corrective justice. Defendant deterrence and plaintiff compensation would seem to demand that wrongdoing defendants be deterred by—presumably hefty—damage awards, and that injured plaintiffs obtain compensation. Yet, vitally, causation does not embody this purpose. The purpose of causation in negligence is not to permit a punishing of wrongdoers through a court sanctioned award of damages to a victim. The purpose of causation is to link the conduct of the defendant before the court to the injury suffered by the plaintiff. ${ }^{171}$ If a wrongdoer is brought before a court by an injured plaintiff, the wrongdoer is only liable to the plaintiff is they are considered legally connected to the injury suffered. ${ }^{172}$ The fact that the defendant has been negligent, and that the plaintiff is injured is irrelevant without a causal relationship to link them. Causation has its formal role in preventing the ingress of distributive justice. To use an example, if Corporation A negligently exposed plaintiff B to a substance that caused him injury, then Corporation A is only liable to Plaintiff B. If Plaintiff B does not pursue Corporation A, then the scope of private law to sanction Corporation A reaches its terminus. If Plaintiff $\mathrm{C}$ is negligently injured by a fourth party, and seeks to make Corporation A liable for this injury, causation intercedes to deny liability, even though Corporation A is a wrongdoer, and Plaintiff $\mathrm{C}$ is an injured party. Global wrongdoing, or

\footnotetext{
170 Richard Goldberg, ed, Perspectives On Causation (Oxford: Hart Publishing, 2011). At 59.

171 Snell v Farrell, supra note 7.

172 Honore, supra note 169 at 126.
} 
wrongdoing in abstraction, are no the subject of the law of negligence precisely because causation forbids them from doing so. Causation's role is to stop generalist accounts of wrong and punishment to incorporate themselves into the fundamentally bilateral nature of the law of negligence: "tort law is not interested in the defendant's culpability aside from the plaintiff's entitlement to redress. The bilateral nature of tort law requires not only asking 'why can this plaintiff recover from this defendant?' but also 'why can this plaintiff recover from this defendant" ${ }^{\prime 173}$ What Weinrib gets to in this extract is that causation makes necessary a relevant link between the plaintiff and the defendant. The strength of this link is up for legitimate contestation, ${ }^{174}$ but causation is there to prevent wider notions of morality from altering the path of causation. ${ }^{175}$ Indeed, a defendant who has wrongfully caused harm normatively should be punished: but it is the role of causation — and the role of courts to uphold this role — to only allow such punishment in the right cases. It is too easy to fudge the causal calculations to permit a wrongful but causally unrelated defendant to compensate an injured plaintiff. ${ }^{176}$ Causation exists, in part, to ensure that the primacy of the bilateral connection between defendant and plaintiff is kept pure, and that distributive or instrumentalist notions do make problematic ingress.

\section{(b) Causation is Not A Freestanding Common-Sense Inquiry}

Equally, causation is not a purely scientific question. ${ }^{177}$ The commonsense interpretation of causation that operates upon the ordinary meaning of 'to cause' is not a useful one. ${ }^{178}$ Hart and Honore conceive of causation as obtaining the purpose of ensuring

\footnotetext{
${ }^{173}$ Weinrib, supra note 67. at 155 (emphasis author's own).

174 Brown, supra note 167.

175 Moore, supra note 165.

176 Vidmar, supra note 149.

177 Sappideen \& Vines, supra note 25 at 144.

178 Tony Honore \& HLA Hart, Causation in the Law, 2nd ed (Oxford: Oxford University Press, 1985).
} 
that common-sense and pragmatism prevail. ${ }^{179}$ Their conception of causation was one that accorded with the seemingly commonsense, but ultimately nonsensical perspective of determining whether, for example, the dropping of a lit match into a wastepaper basket caused the subsequent conflagration. ${ }^{180}$ As a scientific question, operating on the commonsense view of the term 'to cause', the lit match, of course, caused the conflagration; but so did gravity, the presence of oxygen, or the innocent placing of flammable paper in the wastepaper basket. The purpose of causation is not to ascertain all of the necessary conditions for the harm complained of to have occurred. The purpose of causation is determine who has relevant "involvement". ${ }^{181}$ The terms of who is relevantly involved, and also, who is not relevantly involved, occurs within the framework of the law of negligenceand thus, also, the frame of corrective justice. Determining who is involved occurs at an earlier stage in the inquiry: during the 'sorting' phase of establishing to whom, if anyone, the defendant owed a duty of care. ${ }^{182}$ The question of involvement at the stage of the causal inquiry is premised entirely upon a prior answer at the duty of care stage. Despite its importance, the role of causation is not to determine separate, ultimate questions of 'cause' in its ordinary sense, but to answer a relatively binary question: was the party identified at the duty of care inquiry stage responsible for the harm suffered by the plaintiff. The only answers are a yes — that the defendant isolated at the duty of care stage did cause the harmor a no- that the defendant did not cause the harm. The concept of causation is limited to existing within the reduced framework of the other parts of negligence. An external, independent teleological inquiry of what 'caused' an outcome is thus impossible: any such inquiry cannot be external to negligence, because the inquiry itself occurs within the

${ }^{179}$ Lucy, supra note 61 at 183.

${ }^{180}$ Honore \& Hart, supra note 178 at 7.

181 Stapleton, supra note 23.

182 Ibid. 
framework of negligence, and is a corollary of prior questions within the frame of negligence.

\section{(c) Causation is not a Philosophically Independent Concept}

Causation is also not an independent concept. Causation is a vital concept to negligence: but despite this importance, it is only comprehensible within the broader frame of the law of negligence. In our everyday business, everyone undergoes questions of cause. People ask who caused a drop in the stock market, or what caused a cup of coffee to fall from a table, or why fraud caused a business to fail. In an inquiry like this, asking cause has meaning in and of itself. Yet, causation as a legal inquiry cannot operate at a meaningful philosophical concept without the parent concept of negligence. Fumerton and Kress remark that "philosophers have labored long and hard on the question of how to analyze causation, with a striking lack of success". ${ }^{183}$ This striking lack of success accords to the understandably limited purview of these analyses. To work out how to analyze causation as a discrete concept, causation must itself be a discrete concept. Hogg notes the knots that such theorists get themselves into in attempting to divine an autonomous "supernatural concept of causation". ${ }^{184}$ It would be impossible to study the tides without studying the lunar cycle; any such inquiry would have a similarly striking lack of success. Causation is sited within a much broader dialogue: one of responsibility. Causation is not a dialogue in its own right:

we construe the concepts of reasonable care, misfeasance, factual causation, duty of care, and proximate cause, as components of a single normative sequence. As the products of juristic

\footnotetext{
183 Richard Fumerton \& Ken Kress, "Causation and the Law: Preemption, Lawful Sufficiency, and Causal Sufficiency” (2001) 64 Law and Contemp Probs 83 at 102. At 102.

${ }^{184}$ Martin Hogg, "Developing Causal Doctrine" in Richard Goldberg, ed, Perspectives on Causation (Oxford: Hart Publishing, 2011) 40 at 44.
} 
thinking, the concepts are presented to us by positive law, and they invite us to make sense of them and of their normative dimension ${ }^{185}$

Weinrib correctly views causation as part of a sequence: it is a link in a chain, not an atom in a larger organism. Causation is fundamentally linked to the broader narrative in causation of responsibility. The sequence is a single one: to parse and analyze only one element of a sequence is to render irrelevant the preceding and consequent elements in that sequence. Causation doubtlessly has its own role to play in the abstract, philosophical conception of "enhancing moral blameworthiness", ${ }^{186}$ but the concepts of causation are consanguineous to the concepts of negligence. To analyze causation as a separate agent is both a "philosophically naïve"187 and impossible task.

\section{Reaching the Terminus: The Purpose of Causation in Negligence.}

The purpose of causation in the law of negligence is the purpose of negligence. Causation has an essential role in causation, but this role is not a freestanding one. The purpose of causation is to provide coherence to the bilateral structure of the law of negligence. By providing the necessary link between the defendant and plaintiff, causation permits the goals of plaintiff compensation and defendant deterrence. It is with the achievement of these goals that causation is concerned. To put it somewhat bluntly, the goals of causation are beholden to the goals of corrective justice. Causation does not have a unique animus of its own, but instead provides a necessary a link in allowing negligence to achieve corrective justice. Causation serves its purpose best when it maximizes coherence in plaintiff compensation and defendant compensation. When its role is warped to embody purposes beyond that of corrective justice, causation does not embody its purpose, and is

\footnotetext{
185 Weinrib, supra note 67 at 170.

186 Moore, supra note 165 at 20.

187 Alex Broadbent, "Fact and Law in the Causal Inquiry" (2009) 15 Legal Theory 173 at 176.
} 
unable to achieve its goals. This thesis concerns causation, and in writing, this thesis will attempt to maximize the goals of corrective justice, which are so fundamentally intertwined with cause that they are rightly considered inseparable.

\section{A Caveat: Negligence is Underpinned by Corrective Justice, But the World is Not}

The chapter so far has evaluated the law of negligence, and has found that it is most appropriately conceived in terms of corrective justice, and the bilateral rights and obligations between parties. This system does not explicitly countenance distributive, allocative or instrumentalist effects. But, the nature of the legal system does, ultimately generate some of these effects. The legal system is, perhaps by necessity, based upon precedent. When a court in a negligence case assesses the bilateral rights and interests of the parties before it, by making a ruling, the court also assesses the rights and interests of all such and similar parties in the future. ${ }^{188}$ Cane, in wide ranging critique of corrective justice as the exclusive situs for norms in the law of negligence, looks at Donoghue $v$ Stevenson ${ }^{189}$ as an example: ${ }^{190}$

\footnotetext{
Let us assume that before that case the relevant rule of law was that a bystander could not recover against a manufacturer in respect of injuries caused by the negligence of the manufacturer in producing a product. After that case the relevant rule imposed such liability. An effect of the case was, therefore, to redistribute resources (in the form of legal rights) from one group (manufacturers) to another group (bystanders). Therefore, to say that the meaning of private law is corrective justice is to give an incomplete account of the structure of private law. Cane's observation is, ultimately, a correct one. While the law of negligence is
} intended to be an atomistic pocket reality, in which all relationships are bilateral; this reality

\footnotetext{
188 Peter Cane, "Distributive justice and tort law" (2001) NZL Rev 401.

189 Donoghue v Stevenson, 562 AC (1932).

190 Peter Cane, "Corrective Justice and Correlativity in Private Law" (1996) 16 Oxford Journal of Legal Studies 471 at 472 .
} 
is merely a pocket. The rest of the legal and social order is influenced by how this pocket functions, with bilateral resolutions in the pocket operating to change the world at large. There is nothing fundamentally vitiating about such a reality. Cane's prescient observation does not erode the role of corrective justice in tort law. Corrective justice does not perfectly capture the law of negligence; and it most certainly does not capture all of law. It is worth, however, noting throughout this thesis that, despite the necessity of not being other regarding when deciding negligence enquiries, the other regards the law of negligence, and makes decisions based on that observation. Thus, the importance in getting the 'right' resolutions is even more important.

\section{E Summary: Theory of Causation}

The preceding thirty odd pages have simply been a far from simple manner in which to state that the remainder of the thesis seeks to maximize the outcomes plaintiff compensation, and defendant deterrence. In my selection of a deliberately non-exclusionary general perspective of law, this selection drew in the widest ambit of potential perspectives. By narrowing this perspective to the law of negligence, and comparing the two theories that are primarily relevant to this area of law, this section sought to outlay a fair evaluation of the possible theoretical bases of negligence law-the subject of this thesis. Next, in choosing corrective justice as the most valid purpose and core of negligence law, the preceding section made the goals of this theory, the goals of this thesis. With the noting of the centrality of causation to corrective justice, this thesis will now proceed to map a path forward where the corrective justice goals of compensation and deterrence can be more satisfactorily achieved. 


\section{PART TWO: COMPARATIVE LEGAL ANALYSIS}

\section{But-For is Not Hegemonic \& MATERIAL Contribution to Risk is Not So \\ Scary After All: OUtlaying the Different Tests for Causation}

Causation does not have just one test. It is easy to view material contribution to risk as a usurper to but-for causation. It is equally tempting to view material contribution to risk as a potential specter of indeterminate liability: as a "radical step" and "an elimination of proof of causation". ${ }^{191}$ Material contribution to risk is not appropriately considered thusly. Lord Hoffman said: "there is... no uniform causal requirement for liability in tort. Instead, there are varying causal requirements, depending on the basis and purpose of liability". ${ }^{192}$ Vaughan Black refers to this as a tendency to "splitting rather than lumping". ${ }^{193}$

This relatively brief section aims to disambiguate, and unmask, this splitting process. Material contribution is easy to conceive of as a radical departure. It is simple to assert that but-for asks after who caused an outcome, while material contribution asks who contributed to an outcome. This is simple - and simplistic. The difference between the inquiries is not as radical as it seems: this section works to lay out the array of approaches under but-for, as well as outlaying the material contribution approach, to show that they are part of a "causal web": ${ }^{194}$ in which different strands are not a vice, but a virtue. The issue is that the split and different tests involving but-for causation are referred to simply as but-for causation, with little, if any, attempt to noting that they are, ultimately, different tests. When viewed like this, it seems like there is one monolithic, almost inevitable in application but-for test, with

\footnotetext{
191 Clements v Clements, supra note 1 at 16.

192 Kuwait Airways Corporation v Iraqi Airways Co (Nos 4 and 5), 2 AC 883 (House of Lords) at para 128.

193 Vaughan Black, "Decision Causation: Pandora's Tool-Box" in Jason W Neyers, Erika Chamberlain \& Stephen Pitel, eds, Emerging Issues in Tort Law (Oxford: Hart Publishing, 2007) 309 at 310.

194 Stephen Pincus, "Progress On the Causal Chain Gang: Some Approaches to Causation in Tort Law and Steps Toward a Linguistic Analysis" 24 Osgoode Hall Law Journal 961 at 978.
} 
material contribution to risk a foreign outsider. This image is far from reality. By

disambiguating the tests, this section will find that the splitting, not lumping, of causal tests makes material contribution far more familiar than foreign.

\section{A Explaining my Orthodox-Unorthodox Separation}

There are, however, circumstances that, even without scientific precision, orthodox but-for causation is not a useful test. ${ }^{195}$ At this point, it is necessary to note that my typology of causation, insofar as I parse orthodox and unorthodox causation, is an act of my own design.

Many authors consider what I title to be unorthodox but-for to simply be modifications of orthodox but-for, with no attempt to disambiguate them. This lumping, ${ }^{196}$ while seemingly simple, ultimately occludes what is actually happening in the but-for inquiry.

Major $\mathrm{J}$ in Athey $v$ Leonati" ${ }^{197}$ stated, quite accurately, that "the general, but not conclusive test for causation is the 'but for test, which requires the plaintiff to show that the injury would not have occurred but for the negligence of the defendant". ${ }^{198}$ Major J is quite rightly stating that orthodox but-for causation is the de facto test for causation: but that, as needed, new causal tests can and should exist.

Orthodox and unorthodox causation are best considered as similar, but separate tests: they apply in different circumstances, reach different results, and inherently favor different positions.

\footnotetext{
195 Klar, supra note 11 at 450.

196 Vaughan Black, supra note 193.

197 Athey $v$ Leonati, supra note 1.

198 Ibid at 14 (Emphasis added).
} 
By considering unorthodox causation as a part of orthodox causation, it is exceedingly difficult to enunciate when one applies and not the other. Burden shifting butfor reverses the burden of proof. Where it applies, causation goes from being structurally unprovable to being more likely that not to be satisfied. Standard shifting but-for has a similar effect. Inherent in each different causal test are a wide spectrum of normative and policy choices. In what I term 'standard shifted' cases, the learned intermediary rule, which is one example of these standard shifted cases, effectively delineates doctors (whose service is considered normatively desirable) from manufacturers (whose service is normatively opaque), by denying the pro-plaintiff learned intermediary rule's application to doctors, ${ }^{199}$ but not to manufacturers. ${ }^{200}$

The normative inquiries in orthodox and unorthodox causation inquiries are thus fundamentally different. Both use the same counterfactual hypothetical, but their normative, purposive, policy, and application are divergent. To disambiguate the orthodox but-for causal inquiry from the unorthodox but-for doppelganger, it is rather more useful to consider these causal tests as part of a causal array, rather than an opaque overlapping category of but-for. ${ }^{201}$

\section{B Causal Test 1: Orthodox But-for Causation}

In the vast majority of negligence cases, but-for is the causal test that is applied. ${ }^{202}$ Because there, to mind, three different kinds forms of but-for, I refer to the standard form of but-for causation as 'orthodox' but-for causation, and the burden shifting

\footnotetext{
199 Arndt v Smith, [1997] 2 SCR 539 (SCC).

200 Hollis v Dow Corning Corp, [1995] 4 SCR 634.s

201 Vaughan Black, supra note 193 at 310.

202 Klar, supra note 11 at 448.
} 
and standard shifted but-for causal tests as 'unorthodox' but-for causation. The classic statement of orthodox but-for causation is that of Lord Denning in Cork v Kirby Maclean: ${ }^{203}$ “cif you can say that the damage would not have happened but for a particular fault, then that fault is in fact a cause of the damage; but if you can say that the damage would have happened just same, fault or no fault, then the fault is not the cause of the damage" ${ }^{204}$

The gist of orthodox but-for is what is dubbed the counterfactual hypothetical, normally phrased as 'but for the actions of the defendant, would the plaintiff have suffered the harm complained of?' Phrasing the orthodox but-for query like this makes intuitive sense: if you remove the actions of the defendant from the factors that preceded the harm suffered, then there is no way-either morally or logically-that you can state that they, in an ordinary sense, caused the harm suffered.

The orthodox but-for test works particularly well where there is only tortfeasor, and the task of the causal test is to sort in or out the actions of the defendant from the background noise of everyday life. Even in circumstances where there is more than one tortfeasor, orthodox but-for is capable of some contortion, while retaining its nature as orthodox causation. But-for is not invalidated by there being potentially several possible causes: it can be applied in more complex cases, and is clearly capable of being so applied, as causation need not be proven with 'scientific precision'. ${ }^{205}$

\section{Causal Test 2: Unorthodox But-For-'Burden Shifting But-For'}

Burden shifting but-for is the most instantly recognizable form of unorthodox causation. It benefits from a clear and obvious circumstance of its application, and a case

\footnotetext{
203 Cork v Kirby Maclean, [1952] 2 All ER 402 (House of Lords).

204 Ibid at 407.

205 Per Sopinka J Snell v Farrell, supra note 7.
} 
sufficiently comprehensible to have become almost allegorical in nature. Cook $v$ Lewis $^{206}$ is this paradigmatic case. Its facts are well-known, so they bear only brief repeating.

The two primary defendants, hunters Cook and Akenhead, heard a noise in the forest, and simultaneously fired their guns. One round of shot hit Lewis, and one did not. There was no manner of evidence that could reveal which of Cook or Akenhead hit Lewis, nor any way evidence could reveal which of the pair had missed. ${ }^{207}$ It was, in effect, a perfect causal draw. The majority in Cook v Lewis, ${ }^{208}$ wise to the obvious injustice of the outcome, reversed the onus of proving causation, putting the defendants in the obviously impossible situation of proving that they did not factually cause the harm to the plaintiff.

This shifting of the burden was a highly significant one. Without the generation of this rule, Lewis could not have been successful in proving a causative link. The nature of the facts surrounding his injury meant that, under orthodox but-for, proving a causal link was impossible. The view that cause had to be proven by the plaintiff is an ancient one: and one that had not previously been disturbed in Canadian jurisprudence.

It would seem egregiously problematic in Criminal Law to reverse the burden of proof and compel a defendant to prove their innocence, in lieu of the standard form of the prosecution having to prove innocence. This presumption of innocence is a founding element of criminal law.

Yet, such an orthodox sine qua non of the law of negligence was-rightly_ displaced in Cook v Lewis, ${ }^{209}$ and, as precedent, formed the first new unorthodox but-for causal process. What is all the more significant is that the Supreme Court was frank in their

\footnotetext{
${ }^{206}$ Cook v Lewis, [1951] SCR 830.

207 Edward Veitch, “The Many Facets of Cook v Lewis” (2010) 61 University of New Brunswick Law Journal 287 at 289.

208 Ibid.

${ }^{209}$ Cook v Lewis, supra note 206.
} 
statements as to the significance of this generation of an unorthodox but-for causal process. On almost identical facts, the US case of Summers $v$ Tice ${ }^{210}$ was heard just a few years later. There, the California Supreme Court did not forge a new test, but reached a substantially similar result. They did so by resorting to the fiction that the two hunters were operating in concert: functionally grafting joint and several liability on that particular fact pattern, making both defendants globally liable for the harm.

Cook v Lewis did not rely on the same fiction: the Court was frank in their acknowledgment that orthodox causation must undergo change where appropriate to continue to be useful. ${ }^{211}$

In creating the unorthodox but-for burden shifting conception of causation, Cook v Lewis $^{212}$ transformed but-for causation from a hegemonic causal process, to a causal process in which variance and divergence were permissible, even encouraged—where appropriate.

\section{$D$ Causal Test 3: Unorthodox But-For-'Standard Shifted But-For'}

In orthodox but-for causation, the but-for causation needs to be proven at 'probabilistic standard'. ${ }^{213}$ This is a relatively elaborate way to state that it is required only to prove that the actions of the defendant were, more probable than not, the cause of the plaintiffs harm. ${ }^{214}$ This probabilistic standard is phrased in a variety of ways. I prefer the 'more probable than not ${ }^{215}$ phrasing, but another common way to phrase this standard is at 50 per

\footnotetext{
210 Summers v Tice, [1948] 199 Pacific Reporter Series 2d 1.

211 See the (much) later exhortations by the Supreme Court in Snell v Farrell, supra note 7; Clements v Clements, supra note 1 to apply but-for causation in a robust, pragmatic, and commonsense manner. .

212 Cook v Lewis, supra note 206; Edward Veitch, supra note 207.

213 Brown, supra note 167 at $1-10$.

${ }^{214} \mathrm{R} v$ Nette, [2001] 3 SCR 488 at para 13.

${ }^{215} \mathrm{R} v$ Nette, supra note 214.
} 
cent plus one. ${ }^{216}$ Each phrasing should mean functionally the same thing, but, in an area where even fundamental terms are unclear, more elaborate terms lead to even further conceptual difficulties. ${ }^{217}$

The unorthodox causal test that I term 'standard shifted but-for' is, like burden shifted but-for, a new causal test. Unlike ad hoc modifications to rules, standard shifted butfor makes a substantial alteration to one of the foundational elements of cause: rendering it rather radically different. This is alteration takes place at the standard of proof: the level to which cause needs to be determined. This general unorthodox causal innovation occurs in the case of the 'learned intermediary ${ }^{218}$ case. . The following section considers this unorthodox causal approach, reiterating the ordinariness of splitting - rather than clumping — ${ }^{219}$ at the causal test stage.

\section{Learned Intermediary Based Unorthodox But-for}

The learned intermediary rule is a strong example of the permissibility of creating new causal tests. This rule is a coherent, clear, new causative rule. It takes the form of orthodox but-for causation, but forms its own rule when outlining the 'standard' to which causation need be proven. The learned intermediary rule applies when the following factual circumstances are all in place:

- There must be a failure to warn of 'specific dangers that arise from ordinary use of a product $^{220}$; and

- This factual circumstance must involve a manufacturer selling a good; and

\footnotetext{
${ }^{216}$ David A Fischer, "Tort recovery for loss of a chance" (2001) 36 Wake Forest L Rev 605 at 608.

217 See Stapleton, Jane, supra note 22.

218 Hollis v Dow Corning Corp, supra note 200; Arndt v Smith, supra note 199.

219 Vaughan Black, supra note 193.

220 at 20 (Per LaForest J) Hollis v Birch, [1996] 2 WWR 77.
} 
- The good must not be directly purchasable by a consumer, but instead sold to the 'learned intermediary' by the manufacturer, with the learned intermediary then selling on the good.

A real-life example would the act of obtaining prescription medication from one's doctor. There, the doctor would be the titular learned intermediary. If the plaintiff were to be injured as a result of taking this medicine, proving that any failure to warn relevantly caused the injury would be nearly impossible. In such an instance, the plaintiff would be suing the doctor they are the party who would be considered relevantly to have failed to warn the plaintiff. If the manufacturer failed to state, that, for example, the medication will cause injury when combined with insulin, the plaintiff that had combined the two and been injured is placed in an impossible position. They would need to show, using their own counterfactual hypothetical, that the doctor, if she had hypothetically, actually received the warning about combining the medication with insulin, would have then passed this warning on to the plaintiff. It is, in practice, functionally impossible for the plaintiff to show what a defendant doctor may, or may not have done, in the privacy of a consultation room, in a novel hypothetical.

This particular fact pattern makes orthodox causation nearly impossible to prove. Thus, a new causal test is necessary, and was created, with its clearest manifestation in Hollis $v$ Birch. ${ }^{221}$ The learned intermediary rule effectively eliminates the necessity of some parts of factual causation. Factual causation asks, by referring to "objective notions of physical science" 222 how an outcome came about. If the outcome (the plaintiff's injury) would have occurred whether or not the defendant passed the warning on to the intermediary doctor, objective notions of physical science would exclude the defendant's actions from being a

221 Ibid.

222 Sappideen \& Vines, supra note 25. 
cause of the harm. If the intermediary doctor was not going to pass on the warning to the plaintiff, then the failure to warn this intermediary of the risks to the plaintiff makes functionally no difference to the outcome. Frankel JA, in the BC Court of Appeal hearing of Clements $^{223}$ sought to define causation by quoting Linden and Feldthusen's treatise: "(I)f the accident would not have occurred but for the defendant's negligence, this conduct is a cause of the injury... Thus, the act of the defendant must have made a difference". ${ }^{224}$

The learned intermediary rule responds to the factual impossibility of proving this 'making a difference' by no longer requiring it. This is, ultimately, a substantially new causal approach. It is certainly unorthodox in that it no longer requires proof of all of one of the two vital steps of causation-factual cause. Yet, the ordinariness of this approach is also clear. The existing tests could not appropriately select a useful inquiry, ${ }^{225}$ responding to this reality, the necessity of a new test was obvious. Like the creation of any needs-based innovation, the learned intermediary rule, while being new, was a response to a systemic need. Despite no longer requiring what is considered sine qua non to causation, the learned intermediary rule was an ordinary, common-sense response; ${ }^{226}$ and as a result, crafted a rule that defied orthodoxy. This new unorthodox causative rule shifted what was needed to prove cause in certain situations, and in doing so, made a new causal test. ${ }^{227}$ That this change was met by the legal community with not a bang, but a whimper, ${ }^{228}$ shows the ordinariness of this process.

223 Clements v (Litigation Guardian of) Clements, [2010] BCCA 581.

${ }^{224}$ Bruce Feldthusen \& Allen Linden, Canadian Tort Law (Markham: LexisNexis Publishing, 2006) at 116.

225 See Stapleton, supra note 23.

${ }^{226}$ CE Miller, "Causation In Personal Injury: Legal or Epidemiological Common Sense” (2006) 26:No 4 Legal Studes 544; Snell v Farrell, supra note 7.

227 See Buchan v Ortho Pharmaceutical Company (Canada) Ltd, [1984] 46 OR (2d) 113 (Ontario High Court).

228 Klar, supra note 35 at 388-389. 


\section{E Causal Test 4: Material Contribution to Risk}

Like the other unorthodox causal tests, material contribution to risk exists within the otherwise normal process of generating better processes to answer causation questions. ${ }^{229}$ Material contribution to risk, like the other unorthodox causal processes, responds to reality that the existing processes cannot make useful inquiries in response to particular fact patterns.

The following sections go into fulsome depth on material contribution to risk, so a full enunciation here is not a useful process. The mention here of material contribution to risk is to place it in the context of the other forms of unorthodox causal processes.

Unorthodox but-for burden shifting causation exists in order to deal with circumstances like the hunter problem; unorthodox but-for standard shifting causation exists in order to deal with circumstances like the manufacturer-doctor-plaintiff problem; just as material contribution to risk exists in response to problem that cannot be dealt with usefully by the other causal tests. I deal with, at length, when material contribution to risk does and does not apply in section VII; but, to contextualize material contribution to risk amongst the other unorthodox causal approaches, to show its ordinariness, once again the three nurses hypothetical. In this hypothetical, a diabetic is in need of insulin. One dose will make him better, two doses will kill him, and three doses is no more or less lethal than two . Nurses A, $\mathrm{B}$ and $\mathrm{C}$ all separately administer insulin to the plaintiff, and he dies.

Despite the obvious negligence, orthodox but-for causation cannot prove a causal link, because even if any one of the nurses did not administer the insulin, the plaintiff would still have suffered the injury.

\footnotetext{
${ }^{229} \mathrm{~J}$ Stapleton, “An 'Extended But-For' Test for the Causal Relation in the Law of Obligations” (2015) Oxford
} Journal of Legal Studies, online: <http://ojls.oxfordjournals.org/cgi/doi/10.1093/ojls/gqv005>. 
Unorthodox but-for causation is also not a useful test. Burden shifting but-for does not work: each nurse can easily disprove their action as causally irrelevant, because the evidence shows that the same result would have happened even without their actions. Equally, standard shifting but-for is not useful either. All the possible causes are known: there is no evidentiary gap to leap.

It is in this paradigmatic hypothetical that the ordinariness of using material contribution to risk as part of the causal array ${ }^{230}$ to solve a causation problem that would otherwise be unsolvable.

Material contribution to risk, like its fellow unorthodox causal concepts is simply an ordinary and necessary causal process to allow an "obvious injustice",231 to be overcome. Far from radical, ${ }^{232}$ it is indeed, a robust and common-sense application of causation. ${ }^{233}$

\section{F Summary: The Causal Array}

This section has made two closely linked points. Firstly, it has defined and parsed the different causal processes; and secondly, it has contextualized material contribution to risk is only one of the many approaches to cause: it is a legitimate part of Vaughan Black's 'causal array' approach. ${ }^{234}$ The difference between the different tests in the array is how the legal causal inquiry takes place. Orthodox causation has a solid test, that premises itself upon, and prioritizes the primacy of factual causation.

Unorthodox causation, in its various forms, takes a different approach. For each of the different unorthodox causal approaches_-namely burden shifting but-for, standard

\footnotetext{
230 Vaughan Black, supra note 193.

${ }^{231}$ Gregg v Scott, [2005] 2 AC 176, para 54 (Lord Nicholls) .

232 Browning $v$ War Office, 3 All ER 1089 at 1094.

233 Snell v Farrell, supra note 7 at 300-302 It is worth noting that the Court referred to, in this paragraph at least, of the common-sense application of but-for causation. .

234 Vaughan Black, supra note 193.
} 
shifting but-for, and material contribution to risk - a different inquiry is made at the legal causation stage. Unorthodox causation requires something in the neighborhood of probable causative links; but allows for a selection of a causal act as relevant in circumstances where the Court thinks this is fair and reasonable. ${ }^{235}$ Material contribution to risk is ultimately, a different approach to pursuing what is fair and reasonable at the legal causation stage. ${ }^{236}$ It is not radical, nor is it groundbreaking. Material contribution simply acknowledges that the existing causal array of orthodox and unorthodox but-for cannot make a useful inquiry, and, as a result, makes its own inquiry. This section has outlaid orthodox but-for causation, the varieties of unorthodox but-for causation, as well as material contribution to risk. By laying these causal approaches side by side, this section has, with regard to material contribution to risk "pluck(ed) the mask of mystery from its face", ${ }^{237}$ showing it to be more of a logical continuation of causal innovation; rather than a radical, new step in a strange direction.

\footnotetext{
235 Paraphrasing Stapleton, supra note 23 at 435.

236 See Weinrib, supra note 20 at 530 where, in evaluating McGee, Weinrib notes that the existence of the causal inquiry itself is reflective of an underpinning search for fairness. .

237 Jeremy Bentham \& Ross Harrison, "A Fragment on Government” in A Fragment on Government, Cambridge Texts in the History of Political Thought (Cambridge University Press, 1988) at vii.
} 


\section{VI: Furthering the Methodology: MAKIng Apposite Comparisons Between THE UK AND CANADA}

The Canadian conception of material contribution to risk is very much a different conception to the one found in the UK. It is very much tempting to describe the UK approach as the root-stock of material contribution, which has been grafted onto the jurisprudence in Canada. A descriptive process like this is so tempting because it flattens the distinctions between the Canadian approach and the approach in the UK. Its simplicity is strongly alluring. Such a process seems alluring because there has been no judicial explanation for the seeming differences between the Canadian and UK approaches. ${ }^{238}$ Both countries face similar problems in their causative analyses: there is no obvious sui generis nature esoteric to either country that necessitates a special test for liability. ${ }^{239}$

To describe the UK conception of material contribution to risk and the Canadian conception as unified is, however, erroneous. The UK formally considered material contribution substantially earlier than Canada: albeit in a form that is better conceived of as material contribution to harm rather than risk, ${ }^{240}$ although both countries had grappled with causative uncertainty much earlier. ${ }^{241}$ The Canadian approach has, and continues to, show significant divergences from the UK approach. The following brief section undertakes an evolutionary chronology of, firstly, the UK approach, and secondly, the Canadian approach.

This section has the purpose of showing that, while using the same nomenclature and

238 Despite the discussion of Fairchild and Barker in: Clements $v$ Clements, supra note 1 there was no judicial mention of the fact that the Canadian and UK approaches were significantly diverging.

239 Although it could (but hasn't been) argued that Canada could be justified in limiting material contribution to risk to mesothelioma due to the large amount of asbestos mining that occurred in Western Canada, it is the UK, not Canada, that has limited their application of material contribution to risk thusly Stapleton, Jane, supra note 5 .

${ }^{240}$ McGee v National Coal Board, [1973] 1 WLR McGee is probably considered the first time material contribution was formalised into a principle.

241 In Canada, see, for example: Cook v Lewis, supra note 206; In the UK, although Bonnington Castings $v$ Wardlaw, [1956] 613 AC is most commonly cited, ; Nicholson v Atlas Steel Foundry \& Engineering Co, 1 WLR 613 (1957) makes for a significantly better case to review, as the harm there actually involved material contribution to harm, while Wardlaw was more classically but-for. 
following similar bounds, the UK and Canadian approaches are indeed unique ones. In so doing, this section will trace how both jurisdictions have periodically shrunk, then widened, then shrunk again, the importance and application of material contribution to risk. The cases discussed had significant statements on other areas, including on but-for causation, but these case reviews focus duly on the judicial characterization of material contribution to risk.

\section{$A$ The UK Approach: Applied, but Somewhat Variable}

Material contribution to risk has its origins in the UK. It is rather tempting to use a metaphor of grafting the UK approach onto Canadian jurisprudence. This metaphor is a beguilingly simplistic one. The United Kingdom has had a significantly different experience with material contribution to risk. In recent years, the United Kingdom approach has firmed somewhat. In many ways it resembles the Canadian jurisprudence. In many ways, however, it does not. This sub-section selects and reviews the cases that are, for this author, of greatest significance in conceiving of how the UK arrived at their current conception of material contribution to risk, and what this current conception of material contribution to risk is.

\section{McGee v National Coal Board (1973): Starting Material Contribution}

$M c G e e^{242}$ has particular significance to the UK jurisprudence. It stands as an early and highly significant statement on unorthodox causation, with its early, ${ }^{243}$ relatively frank statement of the non-sacred nature of but-for causation lending authority to later cases that took causal unorthodoxy further.

\footnotetext{
242 McGee v National Coal Board, supra note 240.

243 Although other earlier and significant cases defied causal orthodoxy in response to novel fact patterns. See, for eg: Bonnington Castings v W ardlaw, supra note 241 (Pneumoconiosis resulting from silica dust); Nicholson v Atlas Steel Foundry \& Engineering Co, supra note 241 (Pneumoconiosis derived from similar silica dust).
} 
The facts of McGee are, at least in terms of the modern jurisprudence, both uncommon and relatively pedestrian. The plaintiff, Mr. McGee, was employed by the National Coal Board (NCB). His employment involved extensive work inside brick kilns, during which a substantial amount of brick dust would accumulate on his skin. The defendant, National Coal Board did not provide showers in which McGee could wash off the dust, and instead, McGee would have to cycle home in order to shower and wash off the dust. It was settled that the failure to provide the showers was negligence. ${ }^{244}$ At this juncture, the case seems relatively pedestrian. What is uncommon is the injury. McGee argued that as a result of NCB's negligence, he contracted dermatitis, a skin condition known to cause significant pain and discomfort. The significant dispute was whether the need for McGee to cycle home to shower was causally responsible for the dermatitis. There was no negligence involved in exposing McGee to the dust, the only negligence was the failure to provide showers. The risk of suffering dermatitis as a result of exposure to brick is dust is cumulative: ${ }^{245}$ but not divisible. The issue that bedeviled the case was the mix of the sources: the exposure to the dust in the kilns was not tortious, while the 'exposure' due to the absence, and the correlated need for prolonged exposure before safe washing, was tortious. The same mix of tortious and non-tortious sources was seen in $W$ ardlaw, with this case forming the basis of much of the reasoning in $M c G e e$. The Court had to parse non-tortious and tortious sources. Lord Hoffman in Barker summed these sources up as 'at work' dust and 'ride home dust'. ${ }^{246}$ The additional issue was that there being very sparse medical evidence on how precisely dermatitis manifests. ${ }^{247}$ Both the tortious and non-tortious sources were 'causes' at

\footnotetext{
244 McGee v National Coal Board, supra note 240 at 1.

245 Ibid at 2.

246 Barker v Corus, [2006] 20 UKHL at 7.

${ }^{247}$ McGee v National Coal Board, supra note 240 at 5 (Per Lord Wilberforce).
} 
the factual cause stage, but there was no clear enunciation as to whether one or the other should be isolated as 'responsible' at the legal causation stage. ${ }^{248}$

The Court took what was, at the time, a novel approach. The significant earlier case of $W$ ardlaw ${ }^{249}$ was cited by the Court at length. In Wardlaw, the etiology of the disease was relatively well understood to be divisible and cumulative. $M c G e e$, as a result, crafted a new principle, in that it resorted to an unorthodox approach which did not involve but-for; but nonetheless found a causal link. In $M c G e e$, it was not known, nor was it knowable, what influence the extended exposure to brick dust played in the suffering of dermatitis. There was, in effect, an evidentiary gap in what caused the dermatitis: the question for the Court was whether court could leap this gap by applying unorthodox causation. ${ }^{250}$ Like in Clements, the House of Lords closely emphasized that the leaping of the evidentiary gap was a rare and unorthodox process. Stapleton's enunciation of the evidentiary gap required is rather useful here. I paraphrase her impressions of the required form of the evidentiary gap needed to justify aversion to material contribution:

1. The risk of the plaintiff contracting the condition they did must be cumulative: namely, the greater the exposure, the more the illness will be triggered;

2. The injury must also be indivisible: namely, rather than being simply a worsening of an illness, the disease must, once triggered, not vary in severity according to exposure, but have a relatively uniform severity;

3. There must be a single kind of agent to which the plaintiff is exposed;

4. It is not vitiating that some of the harm is non-tortious or non-actionable

\footnotetext{
248 See, for phrasing: Stapleton, Jane, supra note 22.

249 Bonnington Castings v W ardlaw, supra note 241.

250 The phrasing of "leaping evidentiary gaps" has its foundations in the excellent article Jane Stapleton, supra note 6.
} 
5. The contribution of the defendant's negligence to the plaintiff's injury is incapable of, even crude, medical assessment ${ }^{251}$

The Court was acutely aware that the plaintiff, on orthodox causation, would not succeed. By noting the particular curvature of the evidentiary gap suffered by McGee, the Court implemented its own, substantially novel causal process. This process, however, is not material contribution to risk: it is, instead, material contribution to risk of injury. As such, it appears that there was an explicit need for the injury to actualize to be actionable, rather than the simple exposure to risk as being actionable per se. ${ }^{252}$ In McGee, with the injury regarded as indivisible, damages were not raised, the defendant was obliged to pay the entirety of the damages.

\section{Fairchild v Glenbaven Funeral Services (2002): Confirming Material Contribution,}

\section{Rebuffing Wilsber}

In the interlude between $M c G e e$ and Fairchild there were a great many cases that grappled with unorthodox causation. Much like in Canada, not all were successful, with a variety of approaches applied with varying degrees of success. In this interlude the court in Wilsher $^{253}$ had-unsuccessfully_attempted to marginalize McGee. In many ways, the decision in Fairchild brought the law full circle, back to McGee. Stapleton, in an article referred to both in Barker and Clements, refers to the principle in Fairchild as the "McGee/Fairchild Principle", ${ }^{254}$ as if the principle is conceptually inseparable.

The facts in Fairchild, as well as the ultimate outcome, bears passing similarity to McGee.

\footnotetext{
${ }^{251}$ Ibid at 285 Stapleton additionally mentioned that all of the harm was suffered at the defendant's workplace.

${ }^{252}$ For a further application of this, see, for eg: Gregg $v$ Scott, supra note 231.

253 See, with particular attention to Lord Bridge Wilsher v Essex Area Health Authority, [1988] 1074 AC .

254 Jane Stapleton, supra note 6 at 291.
} 
The plaintiff, Mr. Fairchild, was exposed to asbestos particles while working for a series of employers. As a result of this exposure, Fairchild contracted an ultimately fatal case of mesothelioma. As a disease, mesothelioma is particularly pernicious. ${ }^{255}$ It is inevitably fatal, once contracted. It is entirely linked to exposure to asbestos particles; however, there is a moderate background asbestos exposure for every person living in industrialized cities, without any obvious ill effects.

Many people suffer extensive exposure, but do not contract mesothelioma. Some people have only very limited exposure to asbestos, but nonetheless suffer from mesothelioma. In one case, the only recorded exposure for a sufferer was an afternoon playing on an asbestos roof. For another, it was a short afternoon removing a shed. ${ }^{256}$ Famous sufferers of mesothelioma included Steve McQueen-whose only exposure was his asbestos lined flame retardant race suits; and Stephen Jay Gould, a famous biologist—whose only exposure was from asbestos lined specimen cabinets in his academic workplace at Harvard. In at least one case and likely in many, even non-direct exposure to asbestos resulted in mesothelioma. In 1978, a tollbooth operator whose only exposure to asbestos was close proximity to many cars using asbestos lined brakes, was diagnosed with mesothelioma. ${ }^{257}$ In many cases, wives who washed the asbestos covered clothes of their husbands contracted mesothelioma. ${ }^{258}$

Suffice to say, asbestos and mesothelioma cause_ and effect— significant harms. Due to its particular etiology, however, mesothelioma created a substantial, perhaps unique problem for causation. Mesothelioma is indivisible: there are no greater and lesser degrees. Greater exposure to asbestos does not guarantee mesothelioma, as many healthy asbestos

\footnotetext{
255 Stapleton, Jane, supra note 5.

256 Jane Stapleton, supra note 6 at 278.

257 Ibid at 277.

258 Bale v Setsam Pty Ltd, [1996] 288 QCA ; Heil v Rankin, [2001] 272 QB (Queen's Bench).
} 
miners in Western Canada and Australia found out. Lower level asbestos exposure does, however, not preclude mesothelioma, as evinced by the deaths of Stephen Jay Gould, Steve McQueen, and many others. ${ }^{259}$ The period between exposure to asbestos and contracting mesothelioma is, on average, 27 years; thus allowing for many different exposures of asbestos before mesothelioma is suffered.

Medical science still has not established any level of certainty in how asbestos exposure manifests as mesothelioma in some, and not other, people.

As a consequence, Fairchild suffered a particular burden in proving a causal link. He had, over his years of employment, worked for several different employers that had negligently exposed him to asbestos. Many were no longer available to be joined to the litigation. As a result, isolating any one of the defendants as the 'cause' of his injury, with so many competing wrongdoers and lingering medical uncertainty, was an order too tall for but-for causation.

The House of Lords in Fairchild returned to McGee to find that material contribution to risk was indeed an extant principle in UK jurisprudence, and used this principle as the causal test. ${ }^{260}$ Much of the decision by the House of Lords was spent attempting to enunciate when, and how, material contribution to risk, an admittedly exceptional principle, could apply. The House of Lords reasoned extensively from the decision in $M c G e$, in many ways making their decision consanguineous derivation of $M c G e e$. To again draw from Stapleton, there are six factors that are certainly not requirements for the application of material contribution: ${ }^{261}$

1. That the defendant was the only potential source of the risk;

${ }^{259}$ Indeed, UK mesothelioma claims were estimated to cost the insurance industry between six and eight billion pounds Jane Stapleton, supra note 6 at 277.

260 See in Particular Lord Hoffman Fairchild v Glenhaven Funeral Homes, supra note 69.

261 Jane Stapleton, supra note 6 at 292. 
2. That all tortfeasors are before the court;

3. That the defendant was the plaintiff's employer;

4. That the defendant was solely responsible for all the tortious sources of risk to the victim;

5. That there was more than one tortfeasor responsible for tortious exposures; ${ }^{262}$

6. That the defendant's wrongdoing consisted of a failure to act upon a risk that they had themselves created.

It may also be true that not all sources of the harm even need to be wrongful. ${ }^{263}$ Perhaps due to the significance of the case, most of the judges in Fairchild make lengthy attempts at expounding their own perspective on material contribution. This has the misfortune of making the judgment in Fairchild a compendious one, with scarce clarity on which approach is to be preferred. Stapleton notes, and I agree, that there appear to be halfdozen commonalities between the judges that resemble requirements before material contribution to risk can be applied as a principle: ${ }^{264}$

1. There must be a gap in the medical knowledge to the extent that it is not possible to differentiate which factual cause was the most likely 'cause' of the harm;

2. That there must be some pursuit of commercial profit by the defendant;

3. That the injury suffered was a significant, harmful one;

4. That the injury was suffered while at work;

\footnotetext{
262 Note that while this was upheld in Sienkiewicz v Greif (UK) Ltd, supra note 3; It was explicitly ruled out in Clements Clements v Clements, supra note 1, para 42.

263 Fairchild v Glenhaven Funeral Homes, supra note 69, paras 56-65 where Lord Hoffman's does not include this as an essential feature .

${ }^{264}$ Jane Stapleton, supra note 6 at 292-4; Fairchild v Glenhaven Funeral Homes, supra note 69, paras 33, 63, $114,155$.
} 
5. That the defendant required the plaintiff to work with the agent that was the source of their harm;

6. That the harm suffered came from a single agent.

. There is, unfortunately, no authoritative statement of one test, or one approach. This summation is obviously open to disputation; but, for this author at least, these six requirements seem to effectively sum up the best interpretation of what was viewed as the requirements for a case to be able to apply material contribution to risk.

\section{Gregg v Scott: Beginning to Limit Material Contribution to Risk to Mesotbelioma}

Gregg $v \operatorname{Scott}^{25}$ is, compared the remainder of the UK cases surveyed, somewhat incongruous. The facts of Scott had many parallels to the Canadian cases that have particularly vexed the Canadian courts in the last few decades, insofar as all have involved admitted medical negligence and limited scientific tools available to determine the extent of the causal chain flowing from that negligence. ${ }^{266}$

The plaintiff, Mr Gregg, had a tumor negligently misdiagnosed as benign. Between this erroneous diagnosis and the eventual correct diagnosis, many years had passed, with the malignant tumor being allowed spread and reduce his lifespan significantly. The Court was faced with the vexing question of whether the negligence of Dr. Scott constituted a relevant 'cause' of the reduced lifespan, with that reduced lifespan being characterized as the 'harm'.

The House of Lords made two significant points. Firstly, that material contribution to risk did not apply to cases of medical negligence like this one. Despite the fact that Fairchild had explicitly marginalized Wilsher, ${ }^{267}$ the court in Gregg found Wilsher was

\footnotetext{
265 Gregg v Scott, supra note 231 (Scott).

266 See, for eg Laferriere v Lawson, [1991] 1 SCR 541; Athey v Leonati, supra note 1; Snell v Farrell, supra note 7. 267 Which had, itself, attempted to marginalise McGee Wilsher v Essex Area Health Authority, supra note 253 See, especially, Lord Bridge. .
} 
sufficiently factually similar to the case before it, and that, accordingly, Wilsher's marginalization of material contribution to risk $^{268}$ in medical negligence cases also applied. Ultimately, the Court in Scott reached back to Wilsher, and excluded medical negligence as a potential trigger for material contribution to risk, radically reducing potential triggers for the principle.

Secondly, the House of Lords, conscious of the significant value and policy judgments inherent in their decisions, implored for legislative determination of the significant issues before it. Both Lord Hoffman, at para 90, and Baroness Hale, at para 174, who were two members of the three to two majority, expressed clear desire for legislative resolution of the issues before it. ${ }^{269}$

Scott demonstrated significant judicial uneasiness about the scope of material contribution to risk. The Law Lords did not explicitly limit material contribution to risk to be being triggered by mesothelioma claims; but they did explicitly marginalize the principle, and were clear that it does not apply in medical negligence cases.

\section{Barker v Corus (2006): Upholding Fairchild Somewhat, But Considering Apportionment}

Barker $^{270}$ followed soon after Fairchild, but was instead concerned with a significant, but latter question. Fairchild had focused almost exclusively on the causation question, but did not consider in any length, exactly how damages should be apportioned. Both parties agreed in Fairchild to apportion liability on a joint and several basis. Here, apportionment was the key contention.

\footnotetext{
268 See also, Jane Stapleton, supra note 6 at 286-7.

${ }^{269}$ Gregg v Scott, supra note 231; See also C Miller, "Gregg v. Scott: loss of chance revisited” (2006) 4:4 Law, Probability and Risk 227.

270 Barkerv Corus, supra note 246.
} 
The norm in but-for cases is that the defendant is liable in full for the injuries that they have been considered the cause. An exception occurs in cases where the injury is divisible — that is to say occasions where different harms can clearly be attributed different defendants. The standard approach is to apportion damages according to the defendant's share of the injury. ${ }^{271}$ If, for example, defendant A broke a plaintiff's arm, causing $\$ 50,000$ damage; and the independent defendant B broke the unfortunate plaintiff's leg, causing $\$ 200,000$ damage; defendant A would only be liable for $\$ 25,000$; while defendant B would be liable for the more substantial $\$ 100,000$ damage award. For divisible injuries unless defendants were working in concert, ${ }^{272}$ then each is only liable for their contribution.

However, for indivisible injuries like those seen in mesothelioma cases, liability is typically considered joint and several. ${ }^{273}$ The plaintiff can sue any one of the defendants responsible for their injury, and receive compensation in full. That defendant can then pursue the other defendants for their contribution. If one of the also-liable defendants is impecunious, unreachable or insolvent, the defendant named at trial has to bear this additional cost liability. ${ }^{274}$

The Court in Barker was faced squarely with deciding how damages are to be apportioned in material contribution to risk cases. The injury suffered was indivisible, making joint and several liability the apparent rule to apply. However, as an unorthodox rule, it was not clear that the orthodox rules of apportionment still held. It must be noted that at the apportionment stage in but-for causation, the fiction is applied that the defendant is the cause of the harm—thus justifying them paying full damages. To do otherwise would lead to

\footnotetext{
271 Heller v Martens, [2002] 122 ABCA .

272 Which was the fiction the Court used to allow fault, and apportion damages in the US case of Summers $v$ Tice, supra note 210.

273 Dingle v Associated Newspapers Ltd, [1961] 2 QB 162.

${ }^{274} \mathrm{Klar}$, supra note 11 at 567.
} 
unhelpful conjecture on how likely the judicial decision is, and thus reducing the damages amount to any level below one hundred per cent.

To add to the weak foundation of apportionment fictions, material contribution faces a perhaps unique burden upon liable defendants. According to Issacharroff, asbestos litigation in America has left "virtually no first-line asbestos manufacturers (and few of their insurers) left standing", ${ }^{275}$ The average 27 year period between exposure and diagnosis leaves the potential for a great many potential defendants who were responsible for potentially very small exposure to risk; but are left to pay the entirety of the plaintiff's loss. Indeed, in one of the two cases being heard at the same time as Barker, was the case of Smiths Docks Ltd v Patterson. ${ }^{276}$ There, 82 per cent of the harm was attributable to two-insolventdefendants. ${ }^{277}$ This left the defendant at trial who was responsible for only 18 per cent of the risk to being liable for 100 per cent of the injury, without the proof of specific cause that normally renders the at times arbitrary disjuncture between fault and liability.

The facts of Barker were, for present purposes at least, relatively similar to Fairchild. A plaintiff had, while working, been exposed to asbestos, and as a result had contracted mesothelioma. The plaintiff, Barker, had been exposed to asbestos during 3 different, significant periods:

- $\quad$ during a three week period in 1958

- during a seven month period in 1962, while he was working for the defendant, Corus

- during three separate unspecified periods between 1968 and 1975, while working as an independently employed plasterer.

\footnotetext{
275 Sameul Issacharoff, "Mass Torts and Aggregate Asbestos Litigation after Amchem and Orbitz” (2000) 80 Tex L Rev 1925 at 1932.

276 Smiths Docks Ltd v Patterson, [2006] 20 UKHL.

277 Barker v Corus, supra note 246 at 2 (Per Lord Hoffman).
} 
The trial judge had applied the material contribution to risk, applied the liability rule of joint and several liability, but reduced liability by $20 \%$ due to Barker's contributory negligence. The Court of Appeal upheld this judgment. ${ }^{278}$

Unhelpfully, and much like Fairchild, five judges saw it necessary to provide their independent opinions on the case, making the enunciation of a single, clear principle of apportionment in material contribution to risk cases thoroughly elusive.

What is clear, is that the House of Lords was clear in their expression that liability under material contribution to risk was to be proportionate. The fictions that underpin but-for apportionment were not regarded to hold in cases of material contribution to risk. But-for operates, on the fictional level at least, under the presumption that, by the time that damages are apportioned, the defendant has been proven to be the cause of the harm. Material contribution to risk does not operate under the same fiction; the laudable forthrightness of the Court in Fairchild avoided any such fictions. ${ }^{279}$ I see a summation of the views of the five different opinions in Barker ${ }^{280}$ that would, show the following five points to form some form of consensus:

1. The injustice borne upon defendants under a scheme of joint and several liability constitutes a 'compelling reason'281 to depart from the ordinary rule of joint and several liability in indivisible injury cases; ${ }^{282}$

2. That the Court in Fairchild had moved away from the McGee characterization of material contribution to risk of harm. ${ }^{283}$ It seems that the Court in Barker was

\footnotetext{
278 See Barker v Saint Gobain Pipelines PLC, [2005] 3 All ER 661.

279 Jane Stapleton, supra note 6 at 290.

280 Barkerv Corus, supra note 246 where independent judgments were written by Lords Hoffman, Scott, Rodger and Walker, and Baroness Hale.

281 In Barker v Saint Gobain Pipelines PLC, supra note 278, para 44 Kay LJ noted that there need be a "compelling reason" to deviate: and he did not find this to be such a case.

282 Dingle v Associated Newspapers Ltd, supra note 273.

283 Barker $v$ Corus, supra note 246 at 14 (Lord Hoffman).
} 
emphasizing that, where it applies, material contribution to risk is actionable per se, but the somewhat confusingly, that the claim will not be triggered until the harm has been actualized;

3. That, in the imagination of the Court, mesothelioma may well be sui generis, and the principle of material contribution to risk is to apply only to such cases. ${ }^{284}$ Lord Walker stated: ““'The principle must, in my view, be restricted to mesothelioma induced by inhalation of asbestos fibers, and other conditions having the same distinctive etiology and prognosis". ${ }^{285}$ Lord Walker, with Baroness Hale had a statement to almost the same effect; ${ }^{286}$

4. As an addendum to the third point, the Court emphasized that material contribution to risk is an "exceptional" approach. ${ }^{287}$ Lord Scott described it as "anomalous" 288 within the ordinary rules of tort causation, with this seeming representative of the general view of the Law Lords.

The Court in Barker, in the first significant case after Fairchild adjudicated the significant question of how damages should be apportioned under material contribution to risk. On grounds of policy, among others, Barker significantly limited the utility of material contribution to plaintiffs by marking two significant developments. Firstly, and perhaps not entirely surprisingly ${ }^{289}$ material contribution to risk in the United Kingdom appears to be limited to mesothelioma cases. Secondly, liability is to be apportioned according to the rules of proportionate liability.

\footnotetext{
${ }^{284}$ Ibid at 9,15, 16, 21, 26, 39, 40, 41, 56.

285 Ibid at 50 (Lord Walker).

286 Barker v Corus, supra note 246 at 50 per Lord Walker; at 52 per Baroness Hale. .

287 Ibid at 1, 2, 19, 31.

288 Ibid at 29 (Lord Scott).

${ }^{289}$ Following only a year after Gregg v Scott, supra note 231.
} 
Following, somewhat unsteadily, in both the footsteps of Fairchild—which was a step forward for plaintiffs — and in the footsteps of Wilsher ${ }^{290}$ — which decidedly favored defendants ${ }^{291}$ - Barker charted the next step in the UK material contribution to risk jurisprudence.

\section{Compensation Act 2006: Limiting, Seemingly Material Contribution to Risk to}

\section{Mesothelioma Related Harms}

The steps taken in Barker did not leave lasting footprints. Legislative response to Barker was swift, decisive, and clear. With surprising alacrity, only 3 months after Barker was handed down, the Compensation Act $2006^{292}$ was passed by both houses of Parliament.

The Compensation Act had, for the purposes of this thesis, three highly significant sections. Firstly, it provided—in permissive language_-deterrent effects as consideration for courts in determining standard of care. Secondly, it made abundantly clear that damages in mesothelioma claims are to be joint and several. Thirdly, it appears to confirm the suggestion that material contribution to risk applies only to mesothelioma cases.

\section{(a) Section 1: Deterrent Effect of Potential Liability}

The first section was a rather novel one. It is relatively brief, so can be extracted in full:

(1) Deterrent effect of potential liability

A court considering a claim in negligence or breach of statutory duty may, in determining whether the defendant should have taken particular steps to meet a standard of care (whether by taking precautions against a risk or otherwise), have regard to whether a requirement to take those steps might-

\footnotetext{
290 Wilsher $v$ Essex Area Health Authority, supra note 253.

291 Jane Stapleton, supra note 6 at 286.

292 Compensation Act, 2006, c 29 [Compensation Act].
} 
(a) prevent a desirable activity from being undertaken at all, to a particular extent or in a

particular way, or

(b) discourage persons from undertaking functions in connection with a desirable

activity. ${ }^{293}$

This section was not a specific response to Barker. Instead, it was an explicit look towards the ex ante consequences of judicial decision-making. As noted in section IV, despite the law of negligence being underpinned by corrective justice, decisions made within this framework do have substantial instrumentalist effects. ${ }^{294}$ This section was, ultimately, a minimization of corrective justice goals, and an acceptance of instrumentalism in this area. ${ }^{295}$ This section of the Compensation Act explicitly avers to this. The language, however, is not mandatory: keeping the corrective justice view as the core of the law of negligence, but acknowledging that, in the appropriate case, the bigger picture has a role-and perhaps and instrumentalist role- - to play.

\section{(b) Mesothelioma Damages are Joint \& Several}

The second relevant section was a direct and conscious reference to Barker, ${ }^{296}$ overturning the apportionment rule laid down there. It made the liability joint and several, even when there were other tortious ${ }^{297}$ and non-tortious sources of the harm. ${ }^{298} \mathrm{It}$ consciously noted that contributory negligence on the behalf of the plaintiff would, as matter of logic, reduce the damage award by a proportionate amount. ${ }^{299}$

\footnotetext{
293 Ibid, s 1.

${ }^{294}$ Cane, supra note 11.

295 Gemma Rosanne Turton, “Sienkiewicz v Greif (UK) Ltd: a cautionary tale for causation.” (2011) 27

Professional Negligence 166 at 173.

${ }^{296}$ UK Department Of Constitutional Affairs, Compensation Act Explanatory Memoranda (Her Majesty's Stationery Office, London, 2006), para 13.

297 Compensation Act, supra note 292, s (2)(a)(i).

298 Ibid, s (2)(a)(ii).

${ }^{299}$ Ibid, s (3)(a),(b).
} 
Significantly, the Compensation Act made a curious statement on how to determine apportionment between parties: "In determining the extent of contributions of different persons in accordance with subsection (3)(a), a court shall have regard to the relative lengths of the periods of exposure for which each was responsible". ${ }^{300}$ The choice of lengths of exposure is an odd one. The choice of mandatory language- "shall"-is also curious. Apportionment is inevitably "rough justice", 301 but choosing, in mandatory language, contribution is to be directed by period of exposure is very rough indeed. It is unclear what is meant by 'lengths of periods of exposure'. ${ }^{302}$ This may be determined by periods of exposure by one party. ${ }^{303}$ It would likely be functionally impossible to determine on which days during, for example, employment, the plaintiff was actually exposed to asbestosdetermining what the plaintiff did on any one day decades ago would likely be futile process. As such, periods of exposure seems a very rough, but perhaps necessary form of determining contribution.

The fettering of judicial discretion however, is somewhat concerning. Section 4 of the Compensation Act could likely be better conceived by making the language permissive, not mandatory. Working for one defendant, the plaintiff may have been cutting asbestos boards as his primary task - this has a high level of intensity, but is a relatively brief length of period of exposure. At another worksite, the same plaintiff may be working inside asbestos sheds, a task with a relatively miniscule exposure, but with a long 'length of periods of exposure'. The fact that the former defendant would have a reduced culpability, despite exposing the plaintiff to the majority of the risk, seems to emphasize the rough part of 'rough justice'. 304

\footnotetext{
300 Ibid, s 4.

301 Barkerv Corus, supra note 246 at 41 (Lord Rodger).

302 Compensation Act, supra note 292, s (4).

303 See Bonnington Castings v W ardlaw, supra note 241.

304 Barkerv Corus, supra note 246 at 41 (Lord Rodger).
} 
A better phrasing of s(4) would likely be best reflected by either making the language permissive, or instead focusing on intensity and duration. Nonetheless, the Compensation Act crafts and maintains the law in the UK on apportionment under material contribution to risk.

\section{(c) Confirming Material Contribution to Risk applies only to Mesothelioma Related}

\section{Harms?}

The Compensation Act exclusively applies to mesothelioma. The section concerning apportionment is titled 'Mesothelioma: Damages' ${ }^{305}$ The text of the act does mention, nor infer that the apportionment rule applies to damages other than mesothelioma. It appears clear on the text of the Compensation Act that the Parliament considers material contribution to risk to apply exclusively to mesothelioma related harms. The explanatory memoranda prepared in conjunction with the Compensation $A c t^{306}$ is even more explicit. The explanatory memoranda summed up the rule from Fairchild thusly:

The House of Lords decided that a person who had contracted mesothelioma after wrongful exposure to asbestos at different times by more than one negligent person could sue any of them, notwithstanding that he could not prove which exposure had actually caused the diseasebecause all had materially contributed to the risk of him contracting the disease ${ }^{307}$ This interpretation of material contribution to risk as a sui generis test in mesothelioma is the final confirmation that this is the law of the UK. The explanatory memoranda further confirms the view first made explicit in Scott, then expanded on in Barker, and confirmed in the Compensation Act. Material contribution in the UK, notwithstanding the general discussion of triggers in McGee and Fairchild,

305 Compensation Act, supra note 292, s 3.

306 UK Department Of Constitutional Affairs, supra note 296 It is worth noting that this memoranda is not part of the act, nor approved by parliament, thus statements contained therein should be considered with due restraint. .

307 Ibid, para 13. 
in its modern conception is limited to mesothelioma related harms.

\section{Sienkiewicz v Greif (2011): Bringing Single Source Wrongful Harm Cases into the}

\section{(Asbestos Lined) Tent}

Sienkiewicz. $^{308}$ was a significant case; with parallels to Barker and Fairchild. Much of the relevant discussion in Sienkiewicz was esoteric to the law of the UK. Discussions of the socalled 'doubling of the risk doctrine ${ }^{309}$ were a significant part of the analysis in the UK Supreme Court. Such a principle has never been part of the law of Canada. There was also an-ultimately inconsequential-discussion focusing on loss of chance, ${ }^{310}$ which is not a principle recognized in Canadian common law. ${ }^{311}$ For the purposes of this thesis, only one point raised in Sienkiewicz is particularly prescient, as it potentially enlarges the scope of material contribution to risk. This point was the result: in that the UK Supreme Court allowed material contribution to risk to apply to cases where there was only one identified torffeasor.

The facts of Sienkiewič, like Barker and Fairchild, concerned the suffering of mesothelioma as result of negligent exposure by an employer. The novel divergence in Sienkiewicz, was that there was only one actionable source of harm. In Sienkiewicz, the administrators of two estates of women who had died from mesothelioma sued: but they sued only one defendant: Greif. The defendant had employed one woman for 18 years, and had administered the school attended by the other woman. Quite surprisingly, it was honestly acknowledged that, even if the defendant had breached their duty, the vast majority of the exposure to asbestos had occurred from other non-actionable or non-traceable

\footnotetext{
308 Sienkiewicz. $v$ Greif (UK) Ltd, supra note 3.

${ }^{309}$ Hotson v East Berkshire Health Authority, [1987] 2 All ER 909.

310 Sienkiewicz v Greif (UK) Ltd, supra note 3, paras 30-31.

311 Laferriere v Lawson, supra note 266.
} 
sources. ${ }^{312}$ The defendant was simply the only actionable potential cause of their harm. The vast majority of the judgments concerned the esoteric UK principles noted above, but the conclusion in Sienkiewicz is prescient. The Court has expressed marked resistance to the application of Fairchild, referring to its effects on employers as "draconian" at several points. ${ }^{313}$ Nonetheless, the Court took cues from the binding effect of the Compensation Act, the effect of 'policy', as well as the already heavily limited scope of material contribution to risk, and found themselves bound to state that a causal link was, here, satisfied.

Sienkiewicz stands as authority that in the UK single tortfeasor cases can still 'trigger' material contribution to risk, even when the defendants are responsible for a globally minor amount of the harm. This conclusion seems heavily influenced by the strict confines of material contribution to risk; and, given several pointed statements, ${ }^{314}$ it seems unlikely that UK unorthodox causation will be expanded any further.

\section{Summing Up: The Evolution of the UK Approach}

The UK has widely varied the extent of the application of material contribution to risk principle.

In $1971 \mathrm{McGee}$, (erroneously) ${ }^{315}$ citing the unorthodox approach taken in Wardlaw substantially created the principle of material contribution to risk of injury. This conception was clearly limited to the risk having to be of the type suffered by the plaintiff, with the obvious requirement that the risk needed to transform into actual harm.

\footnotetext{
312 Sienkiewicz v Greif (UK) Ltd, supra note 3, para 195.

313 Ibid, paras 58, 184.

314 Ibid, paras 58, 107, 163, 184.

315 See Jane Stapleton, supra note 6 at 283.
} 
In 1988, Wilsher attempted to marginalize $M c G e e$, attempting somewhat vexingly to state that $M c G e e$ had created no new principle of law, but was instead simply applying but-for in a malleable manner.

In 2001, Fairchild substantially marginalized the view in Wilsher, and, likely for the first time, confirmed that material contribution is indeed an independent causal test. On close reading of judgments, it does not appear that the Law Lords considered material contribution to risk to be sui generis to mesothelioma.

Soon after Fairchild, in 2005, Scott showed the first significant stepping back from a broader application of material contribution to risk. The Court in Scott made clear that material contribution to risk does not apply in cases of medical negligence. ${ }^{316}$

The decision in Scott was followed soon after by Barker. From Barker, two significant points can be determined. Firstly, the House of Lords were relatively clear that material contribution to risk applies only to mesothelioma related harms. It certainly was not countenanced that different harms could trigger the application of material contribution to risk. Secondly, the House of Lords, citing potential “draconian” burdens on defendants, and averring to the "pro-defendant" perspective present in Wilsher, formed the opinion that the appropriate liability rule was proportionate to the contribution to risk of the defendant.

Barker was, with remarkable haste, overturned by legislation, with the Compensation Act passed only three months later, amidst much "emotion" on the floors of Parliament. ${ }^{317}$ The Compensation Act rendered liability joint and several; gave instrumentalist concerns

\footnotetext{
316 This particular fact pattern is perhaps the most significant one for the unorthodox causation jurisprudence in Canada. See, for example: Athey v Leonati, [1995] BCJ (Court of Appeal); Snell v Farrell, supra note 7.

317 Richard Goldberg, supra note 170 at 77.
} 
primacy over corrective justice; and emphasized that material contribution to risk applies only to mesothelioma related harms. ${ }^{318}$

The most significant modification to principle on material contribution to risk since has been Sienkiewicz, which, with one eye on the already very limited scope of the principle, allowed its application in cases where only one tortfeasor is available.

In summary, the UK conception of material contribution to risk is a consciously limited one. Rather than being a panacea to systemic problems in causation, material contribution to risk applies only to mesothelioma cases, with the recurrent theme in the cases, especially flowing from $M c G e e$ and Fairchild, being cases where the harmful exposure occurred at work. Liability is, however, joint and several, as a result of the politicized and very 'hasty' passage of the Compensation Act in the fallout of Barker.

\section{$B$ The Canadian Approach: Never Applied, But Wildly Variable}

The Canadian approach seems to diverge significantly from the UK approach. It is, however, difficult to gauge the extent of this divergence without actually having a case which has applied material contribution to risk. The discussion took its first clear enunciation in Snell v Farrell, and perhaps, reached some settling in Clements v Clements. What is clear, however, is that despite using the same nomenclature, and regularly citing the UK decisions on material contribution to risk, the UK and Canadian approaches to material contribution to risk are indeed unique. Both jurisdictions grapple with the same fundamental problems in the causal process, but both have forged their own path. In the Canadian experience, path dependency is unlikely to be a problem, with the lack of binding jurisprudence allowing their unique conception of material contribution much room to improve without stricture. This

318 See, especially UK Department Of Constitutional Affairs, supra note 296, paras 13, 14. 
brief analysis of the Canadian jurisprudence on material contribution to risk will usefully chart the findings and inclinations of the Canadian jurisprudence on material contribution to risk-but it is worth being continually mindful that, without concretization through application in a case, the future of material contribution to risk is not set in stone.

\section{Snell v Farrell (1990): Inching Open the Gate for Material Contribution?}

Snell ${ }^{19}$ was a highly significant enunciation on what is required to prove to causation. The Court in Snell made a series of quite useful remarks in regards to sufficiency of proof in complex fact patterns. The case in Snell was resolved using orthodox but-for causation; but the Court undertook extensive citation of authority to establish sufficiency in causation.

Snell was a medical negligence case, with the plaintiff suffering blindness in one eye after a negligent surgical decision to proceed with surgery after noticing bleeding during surgery. The complicating factor was that there were many competing non-tortious factors, including diabetes and high blood pressure, all of which could have also caused the blindness. Also, the plaintiff (Mrs. Snell) had her eye covered for eight months after the surgery, and thus was not able to determine that she was blind in that eye until the day her eye was uncovered.

In Snell, Sopinka J had several significant remarks on novel causation, potentially, for the first time, opening the door to unorthodox causal analyses like material contribution to risk. ${ }^{320}$ Sopinka J emphasized that orthodox causation was, in the case at hand-and implication most complex causation cases - capable of being a useful causal inquiry. ${ }^{321}$

\footnotetext{
319 Snell v Farrell, supra note 7.

${ }^{320}$ Cheifetz, supra note 12.

321 Snell v Farrell, supra note 7 at at 299.
} 
Sopinka J elaborated on what was required for standards of proof, perhaps averring to the earlier learned intermediary rule cases ${ }^{322}$ where standards were duly shifted. It was elaborately noted that proof-especially proof at the factual cause stage-need not be proven too rigidly. The emphasis was on a robust and pragmatic approach ${ }^{323}$ to the facts of the case. Causation was deliberately phrased by Sopinka J in highly general terms, with the phrasing echoing the corrective justice based enunciation of the law of negligence: "Causation is an expression of the relationship that must be found to exist between the tortious act of the wrongdoer and the injury to the victim in order to justify compensation of the latter out of the pocket of the former". ${ }^{324}$

This phrasing appears a deliberate one. Factual causation is, obviously, part of this relationship, ${ }^{325}$ but this phrasing appears re-emphasizes the importance of the legal causation inquiry. In a simple case, the factual causation inquiry is nearly the totality of the inquiry: A crashed into B, and this was the factual cause of the injury. In the complex case, legal cause is has more relevance. Legal cause sorts the plurality of potential occluding causes, and uses some normative criteria for picking one on the grounds of relationship and responsibility. The court in Snell appears to be emphasizing these two considerations, quite rightly. The parallels between the emphasis on a relationship and justification in Snell, and the note in $\mathrm{R} v$ Nette, ${ }^{326}$ where the Court stated that legal causation is "based on moral responsibility", 327 rightly suggests that

\footnotetext{
322 Hollis v Birch, supra note 220.

323 With Sopinka J in Snell v Farrell, supra note 7 citing ; Lord Bridge (at 569) McGee v National Coal Board, supra note 240 to that effect.

324 Snell v Farrell, supra note 7 at 289-90.

325 David Cheifetz, "Tales of Sound and Fury: Factual Causation in Tort after Resurfice" (2008) Law Society of Upper Canada Special Lectures, Personal Injury.

${ }^{326} \mathrm{R} v$ Nette, supra note 214.

327 Ibid at para 83 .
} 
causation is malleable to the needs of the corrective justice views on reciprocal duties and responsibility. ${ }^{328}$

In Snell, despite the Court asserting this case, and most other complex causation cases, can be usefully resolved with orthodox but-for, significantly removed the need for orthodoxy in causal inquiries. The Court, especially Sopinka J, emphasized that the causal process is a tool to determine responsibility over harm, and that, if unorthodox process is better suited to this determination, then courts should not be timorous in using them. For this thesis, this emphasis is significant: this was the most clear enunciation that new causal processes - material contribution to risk among themwere more than sui generis, but were instead potentially useful parts of the causal $\operatorname{array.~}^{329}$

\section{Atbey v Leonati (1996): A Confusing Trilogy: Part 1}

Athey $^{330}$ is generally regarded to have erred in its interpretation of material contribution to risk. At the minimum, it has since been misinterpreted. ${ }^{331}$ The facts of Athey were not novel facts: ultimately the fact pattern observed in Athey is observed frequently in negligence cases. In 1991, the plaintiff (Athey) had been involved in two separate car accidents. In addition, the plaintiff had a pre-existing back condition. After the two accidents, and while still suffering from the recurrent back condition, the plaintiff was recommended by his doctor, non-negligently, that he resume exercising. Athey, while stretching during such exercise, herniated a disc in his back, causing significant injury. Given

\footnotetext{
328 Weinrib, supra note 20 at see.

${ }^{329}$ Vaughan Black, supra note 193.

330 Athey v Leonati, supra note 1.

331 Cheifetz, supra note 12 at 5.
} 
the medical advice was non-negligent, there were four relevant potential 'causes' of the herniation:

1. The plaintiff's stretching;

2. The first car accident;

3. The second car accident;

4. The pre-existing back injury;

The plaintiffs stretching as potential contributory negligence was not discussed, and was not at issue. The driver in the second car accident was not available to be joined as a tortfeasor. The pre-existing injury had no legally actionable cause. Thus, the only actionable form of harm that could be pursued was the first car accident, in which the defendant at trial had been negligent.

The trial hearing of the case had applied but-for causation, and found that, but-for the actions of the defendant, the plaintiff would not have suffered the injury: thus, the defendant was causally connected to the plaintiffs harm. Damages, however, were reduced by 75 per cent, because the defendant was only one in four of the competing causal possibilities. The trial judge thus reduced the damages by three quarters, awarding the plaintiff only 25 per cent in damages, stating the negligence of the defendant (Leonati) was 'not the sole cause' of the disc herniation, although they played 'some causative role'. ${ }^{332}$ There was no discussion of material contribution to risk.

The case was then appealed to the Court of Appeal. Southlin JA at paras 8 and 9, noted that Athey's counsel put forward a "most interesting argument" in regards to material contribution to risk; but because this argument was not put before the trial judge, it would

332 Athey $v$ Leonati, supra note 1 , para 8. 
be inappropriate for the Court of Appeal to hear such arguments. ${ }^{333}$ The case was duly dismissed.

On appeal to the Supreme Court, Athey was successful, with the full damages being awarded to him for the totality of the injury suffered. The Court, at length, discussed the thin-skull rule: this discussion is not relevant to the case at hand. What is relevant is how the court characterized the material contribution to risk test that had first been raised-but denied hearing-before Southlin JA in the Court of Appeal. ${ }^{334}$ It is worth quoting in full what Major J, speaking for the majority, actually stated:

The "but for" test is unworkable in some circumstances, so the courts have recognized that causation is established where the defendant's negligence "materially contributed" to the occurrence of the injury: Myers v. Peel County Board of Education; [1981] 2 S.C.R. 21, Bonnington Castings, Ltd. v. Wardlaw, [1956] 1 All E.R. 615 (H.L.); McGhee v. National Coal Board, supra. A contributing factor is material if it falls outside the de minimis range: Bonnington Castings, Ltd. v. Wardlaw, supra; see also R. v. Pinske (1988), 30 B.C.L.R. (2d) 114 (B.C.C.A.), affd [1989] 2 S.C.R. $979^{335}$

The selection of citations was significant. In Meyers v Peel County Board of Education, ${ }^{336}$ a student fell and was injured, and there were not crash mats in place, as there should have been. McIntyre J stated on the point of factual causation, that the absence of the crash mats being only one of the factors involved in Meyers' injury was sufficient. ${ }^{337}$ The necessity of factual causation was thus characterized there in very minimalistic terms.

Bonnington Castings $v$ Wardlaw ${ }^{338}$ is frequently cited as an early example of novel causation approaches_-despite the fact that as a case there was relatively little novelty, with

\footnotetext{
333 Athey v Leonati, supra note 316.

334 Ibid.

335 Athey $v$ Leonati, supra note 1 at at para 15.

336 Meyers v Peel County Board of Education, [1981] 1 SCC .

337 Ibid at at 12.

338 Bonnington Castings v W ardlaw, supra note 241.
} 
the harm being divisible, and entirely attributable to the defendant. ${ }^{339}$ The superior case to cite is Nicholson $v$ Atlas Stee $\hat{P}^{40}$ which had present the indivisible injury that is seemingly essential to material contribution to risk.

$M c G e e^{341}$ was a precursor for material contribution to risk, but the characterization there was of material contribution to harm: so great care should be taken in citing $M c G e e$ injudiciously, especially in Canada, where the law of the UK has no binding effect. The view of the majority in $M c G e e$ was generally regarded to have been overbroad: a clearer citation from Major J would have been to refer to Wilsher v Essex Area Health Authority. ${ }^{342}$

Ultimately, the citations by Major J demonstrated confusion on the general nature of the cases cited, and what they stood for in terms of the causal process. In that extract, Major J was effectively making two different assertions: firstly, that where the but-for test is unworkable, material contribution to risk applies; and secondly, that a contributing factor is material if it falls beyond the de minimus range. But-for is 'unworkable' in a great many circumstances, including those where a causative link does, or should exist. And what constitutes the de minimus range, especially in causation causes where detailed medical, statistical and epidemiological evidence is adduced, is very much unclear, although such a standard would seem to be indeed very low. The Court, after its discussion of material contribution to risk in obiter, proceeded on to find that, on the but-for standard, Leonati's negligence had been a 'cause' of the harm, and thus, he was found to be $100 \%$ liable for the injury. Notwithstanding this, Major J, at several points, used 'material contribution'

\footnotetext{
339 Jane Stapleton, supra note 6 at 285.

340 Nicholson v Atlas Steel Foundry \& Engineering Co, supra note 241.

341 McGee v National Coal Board, supra note 240.

342 Wilsher v Essex Area Health Authority, supra note 253.
} 
interchangeably to both refer to the causal involvement of Leonati under but-for causation; as well as in reference to the material contribution to risk test. ${ }^{343}$

\section{Walker Estate v York Finch General Hospital (2001): A Confusing Trilogy Part 2}

Walker Estate was the first substantial consideration of the principle of material contribution to risk after Athey. To use an esoteric phrase, the case was one of dependency causation. ${ }^{344}$ The facts of $W$ alker Estate similarly were not considered to give rise to material contribution to risk analyses; but nonetheless there was extensive discussion in obiter. In Walker Estate, the plaintiff had contracted HIV from infected blood supplied by the defendant hospital. The case hinged on the contention that, if the York Finch General Hospital had used a more rigorous screening process, then HIV infected people would not have donated blood, and thus the Walker would not have contracted HIV as a result of this infected blood. The case was resolved on the basis of the 'strict but-for test', ${ }^{345}$ although several comments were made, in obiter, that are relevant here. The Court stated that "the general test for causation in cases where a single cause can be attributed to a harm is the 'but-for' test. However, the but-for test is unworkable in some situations, particularly where multiple independent causes may bring about a single harm". ${ }^{346}$

The Court in $W$ alker characterized the circumstances so broadly that material contribution to risk is to apply in every case where there are multiple independent causes can bring about a single harm. Every negligence case has competing potential causes: in the fire in the wastebasket example I have used throughout this thesis, the cleaner who did not empty the wastebasket, the presence of gravity, and oxygen, and all number of innocent

\footnotetext{
343 Athey $v$ Leonati, supra note 1 at at paras 44-45 (per Major J).

344 See Clements v (Litigation Guardian of) Clements, supra note 223.

345 Walker Estate v York Finch General Hospital, supra note 1 at 215 (Emphasis added).

346 Ibid at para 87.
} 
factors are ultimately multiple independent causes that can bring about a single harmnamely the wastebasket fire.

Also unhelpfully, the Court noted Major J's comment regarding material contribution to risk applying when but-for causation is 'unworkable' without enunciation of what unworkable actually constitutes. ${ }^{347}$

Walker was, at least, a confirmation that material contribution to risk is indeed a part of Canadian jurisprudence, even if its characterization was a muddled one.

\section{Resurfice Corp v Hanke (2007): A Confusing Trilogy: Part 3}

Resurfice ${ }^{348}$ marks the high-water mark of confusing attempts to discuss material contribution to risk in obiter. Resurfice was satisfactorily resolved on the but-for test, but, despite the significant brevity of the decision, the Court attempted to clear up the confusion arising from Athey and $W$ alker. It did not succeed in doing so, ultimately making the matter more confused than simplified.

The facts of Resurfice were not those that would normally raise discussions of the material contribution to risk test. The plaintiff, Hanke, had suffered serious burns. While attempting to refill the water vessel in an ice-resurfacing machine, he had erroneously inserted the pipe into the fuel tank, causing a leaking of the fuel, then an explosion, which resulted in his subsequent serious burns.

The Supreme Court did, however, make an attempt at clearing up how material contribution to risk was to apply.

\footnotetext{
347 See Vaughan Black, “A Farewell to Causation” (2001) 24 Advocates' Quarterly 478 for a pyrotechnic critique of the rationale in Walker and Athey.

348 Resurfice Corp v Hanke, supra note 1.
} 
The Court reiterated, rightly, that the basic test for causation is the but-for causal process, even in multiple cause injuries. This statement rightly marginalized the confused statement in Walker regarding multiple causes that result in a single harm. ${ }^{349}$

However, less usefully, there was an attempt at rephrasing when the material contribution to risk test is to apply. The Court stated that material contribution to risk was to apply when the following requirements were met:

1. When it is impossible for the plaintiff to prove the defendants negligence caused the plaintiff's injury using the but for test; and that this impossibility is beyond the plaintiff's control; and

2. It must be clear that the defendant breached a duty of care owed to the plaintiff thereby exposing the plaintiff to an unreasonable risk of injury, and the plaintiff must have suffered from that form of injury.

In justifying these two conditions as the combined trigger for the application of material contribution to risk, the Court laid out two examples where material contribution to risk would be appropriately applied:

1. In cases like that in Cook $v$ Lewis $^{350}$ or Summers $v$ Tice, ${ }^{351}$ where two shots are careless fired in the direction of the plaintiff, but it is impossible to determine which injured the victim; ${ }^{352}$

2. In cases where it is impossible to prove that a particular person along the causal chain would have done had the defendant not committed a negligent act or omission, thus breaking the but-for chain of causation. ${ }^{353}$

\footnotetext{
349 Walker Estate v York Finch General Hospital, supra note 1 at para 87.

${ }^{350}$ Cook v Lewis, supra note 206.

351 Summers $v$ Tice, supra note 210.

352 Resurfice Corp v Hanke, supra note 1 at para 27.

353 Ibid at para 28.
} 
With respect, there are issues with both of the requirements; as well as with both of the examples.

The first requirement is obviously problematic: cases where the harm has genuinely not been caused by the defendant will nonetheless satisfy this requirement.

The second requirement is also very much problematic. Ultimately, this second requirement just restates, using different words, the duty of care stage of negligence. It also focuses on the risk of injury: harking back to the now outdated conception from the founding $1971 \mathrm{UK}$ case of $M c G e e,{ }^{354}$ where the focus was on material contribution to harm, not risk as it is currently conceived.

The examples are also curiously problematic. The first example is already capable of resolution using (unorthodox) but-for causation, and has been so resolved satisfactorily in Cook v Lewis, the case to which the Court avers. It is not clear if the Court was attempting to overturn the unorthodox but-for burden shifting approach; or merely stating that if such a case was heard today, it would obtain a different outcome.

The second example is also problematic. The Court was apparently referring to the facts of $W$ alker, but their discussion could apply equally to the learned intermediary fact patterns discussed above in this thesis in Chapter V. Walker was-despite the obitersatisfactorily resolved on orthodox but-for causation; while the learned intermediary cases ${ }^{355}$ are also satisfactorily resolved using the unorthodox but-for for standard shifting approach.

354 McGee v National Coal Board, supra note 240.

355 Buchan v Ortho Pharmaceutical Company (Canada) Ltd, supra note 227; Hollis v Birch, supra note 220. 
The selection of these two requirements, as well as these two examples was puzzling, and, rightly, was sternly criticized by many. ${ }^{356}$ Hanke, despite attempting to clarify the rule on material contribution to risk, significantly muddled the concept.

\section{Clements v Clements (2012): Clearing Up Confusing, Finally-One Hopes}

Clements $^{357}$ stands as the currently authoritative statement on material contribution to risk. Clements was relatively frank in acknowledging the deficiencies of the previous attempts at conceiving material contribution to risk: but it should be noted-but seldom is - that Clements did not overturn Resurfice, but merely reinterpreted the underlying approach to material contribution to risk.

The facts of Clements were relatively direct, and were resolved by applying but-for causation. In Clements, the defendant was driving a heavily overloaded motorcycle over the speed limit, in the rain. At one point, the rear tire was punctured by a nail and eventually, this nail fell out. After the nail fell out, the motorcycle proceeded to wobble, and ultimately fall, with the result being serious injuries to the plaintiff. ${ }^{358}$ The negligence of the defendant in driving an overloaded motorbike in the wet, at speed, was not disputed, ${ }^{359}$ and the case was resolved in favor of the plaintiff.

The Court did have an expansive discussion on material contribution to risk. The weaknesses of the piecemeal approach was implicitly noted, with the Court devoting expansive thought to the law of negligence. Their exposition was significant on two different points: firstly, when material contribution to risk applies; and secondly, on the requirements of but-for causation. The former was a considerable restriction of the previous law on

\footnotetext{
356 Cheifetz, supra note 12; Russell Brown, "Known Unknowns In Cause-In-Fact” (2011) 39 Advocates' Quarterly 37; Cheifetz, supra note 16.

357 Clements v Clements, supra note 1.

358 Ibid at para 1.

359 Ibid at para 2.
} 
point $^{360}$, while the latter seems to have simply clarified lingering uncertainty regarding the Court's intention in previous pronouncements of but for. ${ }^{361}$

\section{(a) Application of Material Contribution to Risk}

Clements significantly constrained the application of material contribution to risk. The triptych of Athey, Walker and Hanke had each attempted to make a different statement on when material contribution to risk applied. ${ }^{362}$ Each case stated it differently. Athey found material contribution to risk to apply when but-for causation was unworkable, but did not determine what unworkable meant. $W$ alker suggested that in cases where there are competing possible causes for the harm, material contribution to risk could apply. This view in $W$ alker does not well reconcile with the reality that even the most simple fact pattern involves potentially competing causes. The definition of the application of material contribution to risk in Hanke was, ultimately, confusing and unclear. ${ }^{363}$ A summary of the three different approaches in those three cases would be that, in cases where but-for causation is bedeviled by some hardship ${ }^{364}$ and a corresponding, but serious hardship affects the plaintiff's ability to prove causation, material contribution to risk may possibly apply.

It is worth noting that Clements did not formally overturn these decisions. They were distinguished, but not overturned ${ }^{365}$ although the status of Walker as law is now unclear. Nonetheless, the law from these cases appears to be of marginal value, as, at least for now, Clements appears to have made a definitive statement of the law. Doubtlessly, Clements will

\footnotetext{
${ }^{360}$ See the wide, or perhaps even nebulous, characterisation of material contribution to risk in, for eg: Athey $v$ Leonati, supra note 1; Walker Estate v York Finch General Hospital, supra note 1; Resurfice Corp v Hanke, supra note 1. 361 See the robust, commonsense approaches in the following cases, which, ultimately, allowed but-for to bend, without breaking, in cases of complex facts Snell v Farrell, supra note 7; Athey v Leonati, supra note 1.

362 Clements v Clements, supra note 1, para 28.

363 Cheifetz, supra note 325.

364 Each defined what constituted what I term a "hardship" in a different manner: Athey v Leonati, supra note 1; Walker Estate v York Finch General Hospital, supra note 1; Resurfice Corp v Hanke, supra note 1.

365 Clements v Clements, supra note 1, para 34 The previous approaches were referred to as "incomplete".
} 
not remain immutable through all of time; but it certainly does appear that the Clements conception of material contribution to risk is a far more sustainable conception than its forbears.

McLachlin CJ, speaking for the majority, started by noting that but-for causation and material contribution to risk are "two different beasts". ${ }^{366}$ The Court also affirmed ${ }^{367}$ that material contribution to risk is "a policy-driven rule of law designed to permit plaintiffs to recover in such cases despite their failure to prove causation". ${ }^{368}$ Recourse to material contribution to risk was emphasized as "necessarily rare", and the centrality of but-for reaffirmed. ${ }^{369}$ Precatory discussions aside, the Court had, for perhaps the first time, a clear enunciation of what it regarded to be the circumstances in which material contribution to risk should apply. I have phrased this as the 'trigger' to material contribution to risk through this thesis.

The significant conceptual process that the Court in Clements went through was to define impossibility. Athey had used this terms its kin 'unworkable' to describe when material contribution to risk could apply, but did not define it. In seeking out impossibility, the Court enunciated the common features across cases that have forced unorthodox causation:

\footnotetext{
Typically, there are a number of tortfeasors. All are at fault, and one or more has in fact caused the plaintiff's injury. The plaintiff would not have been injured "but for" their negligence, viewed globally. However, because each can point the finger at the other, it is impossible for the plaintiff to show on a balance of probabilities that any one of them in fact caused her injury. This is the impossibility of which Cook and the multiple-employer mesothelioma cases speak. ${ }^{370}$
}

\footnotetext{
${ }^{366}$ Feldthusen \& Linden, supra note 224 at 130.

367 Clements v Clements, supra note 1 at para 14.

368 MacDonald (Litigation Guardian of) v Goertz, [2009] 358 BCCA (BCCA) at para 17.

${ }^{369}$ Clements v Clements, supra note 1, para 16.

370 Ibid, para 39.
} 
This seems like a somewhat odd approach. The Court apparently was choosing to make a non-exclusive list of circumstances for material contribution to risk, by showing commonalities in cases to which it may appropriately apply. Of the examples that the Court used here, one is already resolved satisfactorily in unorthodox but-for causation; ${ }^{371}$ while the other has been resolved in the largely sui generis area of UK material contribution to risk jurisprudence. ${ }^{372}$ There is much discussion in the literature regarding factual scenarios termed 'circular causation' ${ }^{373}$ and 'dependency causation'. ${ }^{374}$ The Court in Clements declined to use these labels, but did note that the Court of Appeal judges ${ }^{375}$ who did use these labels were indeed accurate in their identification of the trigger to material contribution to risk. ${ }^{376}$

To summarize the rather clearer, but somewhat opaque approach that the Court in Clements took to the trigger for material contribution to risk, a few insights can be gleaned.

Firstly, the Court in declining to overturn the previous decisions has prioritized what I prefer to term the 'why' over the 'how'. The Court was fairly clear that the approach taken in the earlier decisions was deficient in the case of the latter term: but that that the triptych of decisions referred to earlier were not bumbling, but instead prioritizing the 'why' over the 'how'. The goals of corrective justice, detailed in section IV, provide the core of the 'why' for causal innovation. The earlier cases were aptly emphasizing these goals through the 'why': but, given the pragmatic realities of the judicial system as system of resolving cases between parties, that these earlier cases had not sufficiently phrased the 'how'.

\footnotetext{
371 see Cook v Lewis, supra note 206.

372 Fairchild v Glenhaven Funeral Homes, supra note 69; Barker v Corus, supra note 246; Jane Stapleton, supra note 6.

373 Circular causation is perhaps summed up by Jane Stapleton, supra note 6 at 285.

374 The classic example of such dependency was seen in Walker Estate v York Finch General Hospital, supra note 1. There, reaching a but-for conclusion was dependent upon an inherent uncertainty: what others would have done if the defendant had acted differently. .

375 See Clements v (Litigation Guardian of) Clements, supra note 223.

376 Clements v Clements, supra note 1, para 45.
} 
Secondly, on the 'how', the Court made significant progress. The 'how', here, is the mechanism for actually differentiating between cases that attract orthodox causation, and the cases that attract unorthodox causation. The 'how' is the parsing factor between cases decided on orthodox causal tests, and unorthodox causal tests. The Court enunciated this 'how' as circumstances involving a deficiency the plaintiff's ability to isolate one defendant's conduct from a group of also liable defendants as the 'cause' of the harm. ${ }^{377}$ In finding the 'how' to determine unorthodox causation, the court is taking a pointed but pragmatic view on the moral responsibility to remedy harm involved with wrongdoing. In the rare circumstances that trigger material contribution to risk, mere involvement, as apposed to probabilistic cause, is sufficient to find causation.

Insights other than these two are, of course, possible. But, for the purpose of distilling useful insights for this thesis, these two insights, despite their novelty, are the most significant.

\section{Summing up the Evolution of the Canadian Approach}

Canada has indeed charted their own path through material contribution to risk, following a meandering path to reach some degree of finality in Clements. What is indeed clear is that the Canadian courts struggle manfully with the subject of causation in complex scenarios. In that, they have much in common with the UK.

The early cases of Snell and Athey ultimately determined much of the future course of the Canadian jurisprudence. These cases responded to unique causation problems on the facts by taking a somewhat more relaxed approach to the but-for test. They took the 'robust and common sense' approach and 'inferential' approach, respectively. What can be generalized from these two cases is that there is significant leeriness in relation to departing

377 Ibid, para 46. 
from the standard of but-for causation; with notable enthusiasm for the intermediary steps of crafting unorthodox approaches with but-for causation.

With respect, the obiter in Walker was useful as much for its indication of the difficulty of complex causation cases as it was useful for any enunciation of principle. Walker attempted to clarify the separation between unorthodox but-for and material contribution to risk, but failed to consider the broad reach of the former and the appreciably limited application of the latter. In failing to so consider, Walker unwittingly expanded material contribution to risk at the expense of but-for causation, an outcome it did not appear to wish or intend.

Hanke followed closely in the footsteps of Walker, both in showing the complexity of the causal concept, and in reaching an outcome the inverse of what it intended. The Court in Hanke attempted to define the trigger for material contribution to risk, with accompanying examples where the principle could be useful. Unfortunately for the Court, their enunciation of the trigger was duplicative of part of the test for the tort of negligence, and was otherwise too general. Their selection of examples left much to be desired. ${ }^{378}$ Ultimately, even a narrow reading of Hanke leads to a view of a very wide ambit for material contribution to risk. ${ }^{379}$

Clements stands as the most authoritative statement of the jurisprudence so far. While it will inevitably be subject to later revision, it seems that this conception has staying power. Clements did not rely on labels like circular and dependency causation, but it did cite the Court of Appeal's usage of them somewhat approvingly. The conception of the 'how' part of a trigger took, in Clements a turn for the better. The enunciation of when material contribution to risk applies involved circumstances in which the plaintiff can isolate a class

\footnotetext{
378 Brown, supra note 356.

${ }^{379}$ Lynda Margaret Collins \& Heather C McLeod-Kilmurray, "Material Contribution to Justice? Toxic Causation after Hanke v. Resurfice" (2011) Toxic Causation after Hanke v Resurfice (July 1, 2011), online: $<$ http://papers.ssrn.com/sol3/papers.cfm?abstract_id=1883714>.
} 
of defendants who 'caused' their harm; but cannot specify further. As part of this trigger, the 'why' for applying material contribution to risk clearly reflected the corrective justice underpinnings of negligence. The 'why' was necessarily imprecise. To be brief, the Court saw residual or systemic unfairness in using but-for derived tests as the key reason for applying material contribution to risk. From Clements, the 'why' of fairness seems the animus for material contribution to risk, seems to be bounded by the 'how' of the need for the particular factual matrix.

\section{Doing the Comparison: What Useful Contrasts and Commonalities Can be Observed Between the UK and Canada}

There are more differences between the Canadian and UK legal spheres than any author could list. Any bare comparison between jurisdictions of a point of law must be undertaken in a manner that wards off over-boldness or the flattening of insuperable differences. ${ }^{380}$ There, are however, some useful comparisons that can be made between the two jurisdictions. The UK and Canada are sufficiently similar that comparing them, rather than being like comparing apples and oranges, may be better conceived as comparing tangerines and oranges. Some comparisons, with the appropriate caveats, can be usefully made. Differences do not always preclude useful comparison, if they are appropriately considered and factored in. Between the UK and Canadian approaches to material contribution, I see there to be a half-dozen useful insights that can be derived. Some are marked contrasts, while some are unsurprising commonalities. By analyzing the different approaches in the different jurisdictions as I have in the preceding paragraphs, it is able to

\footnotetext{
380 Mark Van Hoecke \& Mark Warrington, “Legal Cultures, Legal Paradigms and Legal Doctrine: Towards a New Model for Comparative Law” (1998) 47:03 International \& Comparative Law Quarterly 495.
} 
make significant insights, and give significant backing to arguments made in the following two sections on triggers and apportionment.

\section{Commonality: Both Jurisdictions Find This Exceedingly Difficult}

The most obvious commonality between the two jurisdictions is that the subject matter is exceedingly difficult. Courts in both jurisdictions are acutely aware that they are making significant determinations on subjects that closely intersect with nebulous policy considerations. The UK courts, as well as the legislature, resorted to applying instrumentalist approaches to material contribution to risk in order to mitigate the potential fallout from expanding the principle. ${ }^{381}$ The Canadian courts have taken a different path in managing policy, choosing to stick to modifying but-for causation for the moment. ${ }^{382}$ Both approaches reflect the reality that material contribution to risk deals with a vastly problematic combination of metaphysics, science, and the limits of 'knowing'; ${ }^{383}$ with judicial temerity unsurprising in that regard. Equally, in both jurisdictions, the road to the current positions has been winding. The UK has vacillated between positions that seem advantageous to the plaintiff ${ }^{384}$ and positions that favored the defendant. ${ }^{385}$ Canada has characterized (but never applied) material contribution to risk in ways that seemed to make readily available to vulnerable plaintiffs and characterized it in far more limited terms.

\footnotetext{
381 See Gregg v Scott, supra note 231; Barker v Corus, supra note 246.

382 See Snell v Farrell, supra note 7; Athey v Leonati, supra note 1; Cook v Lewis, supra note 206; Hollis v Birch, supra note 220 .

383 See Patricia W Cheng, "Separating Causal Laws from Casual Facts: Pressing the Limits of Statistical Relevance" in Douglas L Medin, ed, Psychology of Learning and Motivation (Academic Press, 1993) 215.

384 On the one hand: McGee v National Coal Board, supra note 240; Fairchild v Glenhaven Funeral Homes, supra note 69.

385 On the other: Gregg v Scott, supra note 231; Barker v Corus, supra note 246.
} 


\section{Contrast: There Is a Fundamentally Different Legal Environment}

The cases seen in the UK and Canada reflect an inherent divergence in the underpinning legal regime.

The earlier cases in the UK appeared to be suggesting a requirement in the trigger that involved the defendant resembling an employer. ${ }^{386}$ Thus, all of the cases surveyed in the UK involved an employee/plaintiff suing their employer/defendant. This reality likely allowed the critical mass of cases to arise for the principle of material contribution to risk reaching the highest court in the land.

The Canadian cases show their legal substratum. Unlike the UK, injuries suffered in the workplace are resolved extra-judicially, through statutorily mandated workplace injury schemes, administered both federally ${ }^{387}$ and province to province. ${ }^{388}$ These schemes largely preclude plaintiffs from recourse through suing employers. As a result, the factual matrices in which material contribution to risk analysis can be engaged shrinks dramatically. Of course, it is possible for exposures like those in McGee, Fairchild, Barker or Sienkiewicz to occur outside of the employee-employer duty of care relationship; such possibilities are obviously significantly rarer, likely stifling the development of material contribution to risk in Canada.

\footnotetext{
386 The twinning of this element seen in both McGee and Fairchild was first, and best, enunciated by Jane Stapleton, supra note 6 at 291-3.

387 Government Employees Compensation Act, RSC 1985, c g-5 [Government Employees Compensation Act].

388 Workers Compensation Act R.S.B.C. 1996 c. 492 (British Columbia) [Workers Compensation Act R.S.B.C. 1996 c. 492 (British Columbia)] at See, for eg:
} 


\section{Contrast: The Legal History of Material Contribution To Risk Diverges Widely}

\section{Between Jurisdictions}

Stare decisis is another form of what economists term 'path dependency' ${ }^{389}$ In law, there are inherent and normative benefits of the predictability inherent in following an established case and the accompanying principle. ${ }^{390}$

The path that the United Kingdom took in its approach to material contribution to risk had early and fulsome enunciation. McGee stands as the highly significant case that laid the trammeled path towards the position seen in the UK today. ${ }^{391}$ By having the substratum of unorthodox causation cases already, ${ }^{392} \mathrm{McGee}$ created the path for the later courts to follow in forming the modern characterization of the material contribution to risk.

Canada, however, did not have the fundamental early case to follow. MoGee was an outlier; the Canadian jurisprudence has had no such outlier, with its jurisprudence following the trammeled path of permitting unorthodox approaches to the otherwise orthodox but-for causal approach.

\section{Contrast: The Triggers are Widely Divergent}

The clearest area of useful distinction between the UK and Canada is the trigger for applying material contribution to risk. This statement can be made rather more objectively, by focusing on the 'how', not the 'why'.

The UK conception of the trigger is a very narrow one. It has narrowed precipitously since its origins in $M_{c} G e e$ and crystallization in Faircbild. After Barker, Scott and the Compensation Act, it is relatively clear that only cases where the actionable harm is

\footnotetext{
389 Morris Altman, "A behavioral model of path dependency: the economics of profitable inefficiency and market failure” (2000) 29:2 The Journal of Socio-Economics 127.

390 John Morris, “The Proper Law of a Tort” (1950) 64 Harv L Rev 881 at 882.

391 Jane Stapleton, supra note 6 at 289.

392 Bonnington Castings v W ardlaw, supra note 241; Nicholson v Atlas Steel Foundry \& Engineering Co, supra note 241.
} 
mesothelioma will suffice to trigger the application of material contribution to risk. It is not clear whether the apparent requirement from Fairchild and McGee that the defendant have been in pursuit of some commercial profit while they committed their negligent act continues to operate. It certainly has not been tested.

In Canada, however, the trigger is appreciably broader. Doubtlessly, mesothelioma claims would be within the trigger in Canada, but is not the limit. ${ }^{393}$ In Clements fact patterns like that seen in Cook were also cited as potentially triggering material contribution. ${ }^{394}$ There was also the additional focus when discussing the trigger that the application was to be flexible. Clements emphasized injustice as the 'why' to trigger material contribution to risk; with the appreciable limit on this being that there must be a group of negligent, potentially causally responsible, tortfeasors; with the plaintiff in the invidious position of not being able to isolate any one as the 'cause' of their harm.

The UK and Canadian approaches to the trigger to material contribution to risk are the starkest and most ready distinction between the two jurisdictions.

\section{Contrast: Conceptions of The Apportionment Rules May Be Distinct}

The differences between the countries on apportionment are, however, mere suppositions on my behalf.

The UK Court in Barker averred extensively to instrumentalist concerns in rendering the liability in material contribution to risk cases to be proportionate. The Compensation Act, in a novel show of the perverse vagaries of law, applied the same instrumentalist concerns to reach precisely the opposite conclusion: that material contribution to risk should be joint and

393 Clements v Clements, supra note 1, para 39.

394 Ibid. 
several. ${ }^{395}$ Barker had been duly conscious of the effect on future employers if the liability had been joint and several; the Compensation Act was conscious of this effect, and wished for employers to be conscious as well, hopefully leading to deterrence. ${ }^{396}$

In Canada, with apportionment never discussed in the Supreme Court, and with no appellate court application of material contribution to risk, evidence of an approach to a trigger is rather more sparse. Some divinations are, however, possible. The Canadian approach, while not plaintiff-centric, takes injustice to plaintiffs as its paradigm. ${ }^{397}$

In Canada, material contribution is not seen as a sword to slay negligence by defendants; but is instead a shield to protect negligently injured plaintiffs. The UK legislative approach seems to view material contribution to risk as the sword, rather than the shield. For Canadian apportionment, this shield, not sword, approach does perhaps suggest that a future judicial decision on apportionment may favor an approach that would result in substantial plaintiff compensation. Proportionate liability, given the fact patterns that typically exist in material contribution to risk cases, is unlikely to achieve this on its own. The judicial emphasis seems to be on fairness to the plaintiff: this was particularly starkly reiterated in Clements. ${ }^{398}$ Which apportionment scheme will apply has not been averred to, even implicitly_and I discuss an ideal choice in section VIII-but it is likely that any such scheme would be one that privileges plaintiff compensation and defendant deterrence over the potential for undue punishment and over deterrence. ${ }^{399}$

\footnotetext{
395 Turton, supra note 295 at 170.

396 Compensation Act, supra note 292, s 1.

397 See especially Resurfice Corp v Hanke, supra note 1, paras 25-26 where, in an implicit support of Fairchild, the Court noted that where applying orthodox but-for would "offend basic notions of fairness and justice", the Court would not hesitate to apply a novel test. .

398 Clements v Clements, supra note 1, paras 16, 19, 21, 25, 27, 32, 42, 45.

399 Cf: S. Green, supra note 13 for the view that material contribution significantly over-penalises and deters the defendant.
} 


\section{Commonality: The Jurisprudence Now Seems Stable in Both Jurisdictions}

Finally, it seems that both jurisdictions have reached a point of equipoise. After a relatively swift series of cases in the 2000s in the UK, and a similar back and forth between 1996 and 2012 in Canada, the current statements of law seem to have substantially settled the matter for now. In Sienkiewicz, the Court emphasized at length the value in stability, with Lord Brown very pointedly noting that the "law which benefits perhaps above all from clarity, consistency and certainty in its application". ${ }^{400}$ The extent to which the Court went in Clements to finally resolve a decade of confusion seems to suggest a similar finality in their judgment. It seems that, for now, the law feels settled, with Courts valuing a settled principle over new innovation.

\section{Summary: Comparisons}

The law of the UK and Canada has had a torrid time of resolving their individual approaches to material contribution to risk. Both countries have struggled with crafting their unique solution to the daunting combination of scientific uncertainty, factual complexity, normatively vast implications, policy, and fairness. This section has traced the significant moments in both countries. The moments chosen each reflected a marked alteration to a relevant area of material contribution. Some moments were a step backwards, some were a step forwards, and some were perhaps not even steps at all. Four brief summative observations are thus possible:

1. that the UK conception of material contribution to risk is a very narrow one;

2. that the UK, over judicial resistance, applies joint and several rules of liability;

\footnotetext{
400 Sienkiewiczv Greif (UK) Ltd, supra note 3, para 182.
} 
3. that Canada now has a conceptually viable trigger, albeit one markedly wider than the one seen in the UK;

4. and that Canada, as yet, has no finite position on how damages are to be apportioned.

The final two points are need of significant elaboration before any method of clarity is obtained. The remaining part of this thesis is exclusively concerned with this task. 


\section{PART THREE: CONCEPTUAL ANALYSIS}

\section{FINDING BoTH THE ‘HOW’ AND THE ‘WHY’ For TRIgGERINg MATERIAL CONTRIBUTION To RISK}

To trigger material contribution to risk, there needs to be both a particular fact pattern, and something akin to an 'x factor' that will compel a court to apply material contribution to risk. The fact pattern is the 'how' material contribution to risk gets triggered, while the $\mathrm{x}$-factor is the 'why'. Clements ${ }^{401}$ stands largely alone at this juncture in outlining the 'how'; why a pastiche of the views in Clements, Hanke, ${ }^{402}$ Walker, ${ }^{403}$ Athey ${ }^{404}$ and Snell ${ }^{405}$ outline the 'why'. The 'trigger' is a concise, albeit casual, term used here to mean the circumstances where material contribution to risk instead of but-for causation is applied. When the trigger is 'pulled' material contribution applies in lieu of the more orthodox causal processes.

The Court in Clements made a significant beginning at stating the fact patterns in which material contribution to risk can apply. It seems that the Court stated the core circumstances that will trigger material contribution to risk: ${ }^{406}$ but without a strong history of applied cases of material contribution to risk, there is no line on how far this core can expand. Their attempts at defining the 'how' are thus somewhat unbounded. The judicial enunciation of the 'why' must be read in light of this 'how'. Obviously, not all cases of manifest unfairness to the plaintiff will grant recourse to the less taxing material contribution to risk causal process. As such, the 'how' and 'why' of applying material contribution risk must be read closely in light of each other. Clements left a series of significant questions

\footnotetext{
401 Clements v Clements, supra note 1.

402 Resurfice Corp v Hanke, supra note 1.

403 Walker Estate v York Finch General Hospital, supra note 1.

404 Athey $v$ Leonati, supra note 1.

405 Snell v Farrell, supra note 7.

406 See especially Clements v Clements, supra note 1, paras 39, 46(1)(2).
} 
hanging. Three questions pertain directly to what fits in within the 'how' of material contribution to risk. The circumstances that trigger material contribution to risk-the 'how' - will, in the distant future, be well enunciated by a long series of court cases. At the moment, which facts that may, and may not trigger material contribution to risk are not ultimately clear. Given the litany of cases that have confirmed material contribution to risk's existence without it yet being applied; ${ }^{407}$ it seems likely that clarity is needed before the principle can be applied and developed.

Three significant questions exist in that need clarification. Firstly, does the Canadian principle mirror the UK principle in requiring the harm to be mesothelioma? Secondly, are circular and dependency causation scenarios necessary, sufficient, or irrelevant to triggering material contribution to risk? Thirdly, did the Court mean to exclude single tortfeasor actions, or single wrongdoer actions?

There is an interesting, and as yet unexplored question, that seems to have been missed by the burgeoning literature in relation to Clements. What of the remainder of unorthodox causation? The Court in Clements, and at many other times, referred explicitly confirmed that but-for causation remains the de facto test of causation. But, in citing circumstances that material contribution to risk may apply, Clements implicitly referred to two of the significant unorthodox causal processes: namely burden shifting in Cook, ${ }^{408}$ and the standard shifting in Hollis. ${ }^{409}$ If Cook or Hollis was heard today, was the Court in Clements saying that they would be resolved by material contribution to risk? If the answer is yes, material contribution to risk has effectively cannibalized the rest of unorthodox causation. If

\footnotetext{
${ }^{407}$ See, for eg: Barker v Montford Hospital, supra note 1; Jackson v Kelowna General Hospital, supra note 1; Fullowka v Royal Oak Ventures, supra note 1; Seatle v Purvis, supra note 1; Resurfice Corp v Hanke, supra note 1; Clements v Clements, supra note 1.

408 Cook v Lewis, supra note 206.

${ }^{409}$ Hollis v Birch, supra note 220.
} 
the answer is no, then material contribution to risk has carved itself the smallest of niches in which it can conceivably apply.

These questions are not the totality of uncertainties relating to the trigger. It is not clear whether divisible harms can trigger material contribution to risk; nor is the role of material contribution to risk in mass torts clarified. ${ }^{410}$ This thesis does not deal with these concerns - understanding their depth would entail the opening of many new matryoska dolls of concepts, with the associated need of dozens of explanatory pages. Mass torts and divisible harms, among the other confusions, seem relatively rare in application—-this thesis attempts to keep its focus on the most frequently occurring confusions-and thus leaves these topics for another day, or another author.

Having been partly defined, but not applied, the trigger to material contribution to risk is elastic. The following section probes the statement of the 'how' from Clements to see how far material contribution to risk stretch before it breaks.

\section{B Answering the Clarity Questions: Clarifying the Bounds of the Trigger}

The following four questions are each potential causes for confusion. Particularly to courts of first instance, these four questions, if answered one way, may either unfairly shrink the trigger to material contribution to risk; and, if answered another, may unnecessarily expand it. In answering these four questions, what is, and is not, contained within the trigger to material contribution to risk will become increasingly clear.

\footnotetext{
410 Clements v Clements, supra note 1, para 44; See also Collins \& McLeod-Kilmurray, supra note 379.
} 


\section{Question 1: Does the Harm Have to Be Mesothelioma?}

When reading Clements in conjunction with the expansive UK cases, it is easy to allow the approaches to bleed into each other. Both use the same nomenclature; and UK doubtlessly has the longer history, and more fulsome enunciation. It is important to emphasize — which Court in Clements did not ${ }^{411}$ — that the UK and Canadian conceptions of material contribution to risk are substantially different. The principle of material contribution to risk is, in the UK, its own unique species. The later interpretations of the material contribution to risk principle flowing from Fairchild, ${ }^{412}$ in Barker, ${ }^{413}$ The Compensation Act, ${ }^{414}$ and Sienkiewič. ${ }^{415}$ as being only a triggered by mesothelioma related harms. It is tempting that the substantial ground-breaking case of Fairchild should be read of the authoritative statement of the UK law. This characterization has much in common with the Canadian law today. This characterization is, however, no longer in force. The descendants of Fairchild thoroughly limited material contribution to risk, to the extent that only mesothelioma cases can trigger material contribution to risk. ${ }^{416}$

In Canada, material contribution to risk is not limited to mesothelioma cases.

Clements, nor any other case, has intimated or stated such a proposition. It is useful to extract, at length, the paragraph in which the absence of such a limitation was expressed:

What then are the cases referring to when they say that it must be "impossible" to prove "but for" causation as a precondition to a material contribution to risk approach? The answer emerges from the facts of the cases that have adopted such an approach. Typically, there are a number of tortfeasors. All

\footnotetext{
411 While both the Supreme Court and BC Court of Appeal iterations of the case referred to the UK cases, neither noted that the UK jurisprudence had fundamentally different roots and application Clements $v$ Clements, supra note 1; Clements v (Litigation Guardian of) Clements, supra note 223.

${ }^{412}$ Fairchild v Glenhaven Funeral Homes, supra note 69.

413 Barker v Corus, supra note 246.

414 Compensation Act, supra note 292.

415 Sienkiewicz, $v$ Greif (UK) Ltd, supra note 3.

416 Ariel Porat \& Alex Stein, "Indeterminate Causation and Apportionment of Damages: An Essay on Holtby, Allen, and Fairchild" 23:4 Oxford Journal of Legal Studies 667.
} 
are at fault, and one or more has in fact caused the plaintiff's injury. The plaintiff would not have been injured "but for" their negligence, viewed globally. However, because each can point the finger at the other, it is impossible for the plaintiff to show on a balance of probabilities that any one of them in fact caused her injury. This is the impossibility of which Cook and the multiple-employer mesothelioma cases speak. $^{417}$

The Court, while referring to mesothelioma, was quite explicitly releasing material contribution to risk from being linked only to mesothelioma. The description of the 'how'the relevant factual scenarios- is consciously not fact specific. The use of the term 'typically', the generalness of the conditions, and the reference to Cook- a case that involved gunshots, not asbestos - all lead to the view that material contribution to risk is not limited to mesothelioma cases. Certainly, cases where the harm suffered is mesothelioma may well be within the trigger to material contribution to risk. What the Court in Clements makes clear is that the material contribution to risk is not limited to such scenarios.

\section{Question 2: Can Material Contribution To Risk Expand Beyond Circular and Dependency Causation-And Should It?}

This question squarely goes to how far the trigger can expand. Currently, the trigger enunciated in Clements emphasizes the 'why': with allusions to injustice and unfairness providing a normative reason for the application for material contribution to risk. What is far from clear is what facts will trigger discussion of the 'why', and the possible application of material contribution to risk to the case at hand. The description of the factual scenarios that may apply were stated only the broadest generalities in Clements. This sub-section attempts to ask whether there can be any definition of the 'how' in material contribution to risk can apply.

417 Clements v Clements, supra note 1, para 39 (Emphasis added). 
In Clements, the Supreme Court was generally in approval of the decision-making made in the case's hearing in the BC Court of Appeal, noting three times in quick succession on the correctness of Kay LJ's identification of triggers to material contribution to risk. ${ }^{418}$ The Court in Clements did, however, deviate slightly on one point. In the BC Court of Appeal Kay LJ stated: "Professor Knutsen's view, with which I agree, is that a judge can resort to the material contribution test in only two situations: what he refers to as ones involving circular causation and dependency causation. In all other cases, causation must be determined on the butfor test." ${ }^{419}$

In the Supreme Court, however, the Court stated "It was unnecessary in my view to hang the analysis on 'circular causation' and 'dependency causation' which may complicate the matter rather than simplify it". ${ }^{420}$

It seems that the Supreme Court was generally supporting the view that circular causation and dependency causation are useful examples, but not exclusive ones. The lack of any condemnatory language, and the statement that it "was unnecessary in my view to hang the analysis" ${ }^{421}$ on these terms suggests that, at base, the terms circular and dependency causation are useful ones. What I am trying to divine here is whether circular and dependency causation fact patterns are necessary, sufficient, or irrelevant to triggering material contribution. Defining circular and dependency causation goes a long way to this clarifying the issue.

\footnotetext{
418 Ibid, para 45.

419 Clements v (Litigation Guardian of) Clements, supra note 223, para 54 (Emphasis added).

${ }^{420}$ Clements v Clements, supra note 1, para 45.

421 Ibid.
} 


\section{(a) Defining Circular Causation}

Circular causation is best demonstrated by a description, an example, and then a case. Circular causation occurs when there is a series of potentially liable defendants, but each can point their finger to one of the other defendants as the potential cause of the plaintiff's harm - these circumstances occur particularly frequently in information poor environments. For example, if a dozen rioters were to throw a dozen rocks, with a ten broken noses from rocks suffered by police, each of the rioters could claim causal innocence, by pointing their finger at other rioters as the potential cause of the harm. The paradigmatic case to demonstrate circular causation is Cook v Lewis, wherein two hunters negligently fired their guns, with one hitting, and one missing, the plaintiff. Science could not prove whose shot hit and who missed; thus each hunter could finger point, and, on orthodox-but-for, could avoid causal responsibility. Such a result is circular because each defendant can point to another defendant's wrongdoing as the cause.

\section{(b) Defining Dependency Causation}

Dependency causation is also best demonstrated by a description, an example, and a case. Dependency causation involves an act of negligence, with the causal chain either broken or occluded by the impossibility of determining what a person on the chain may have done. For example, imagine if a doctor negligently failed to warn the a mother that her chickenpox may result in serious birth defects in her child; finding a causal link between the defendant and the injury suffered by the child would be dependent on proving whether or not the mother would, or would not have had an abortion if she was furnished with the information. ${ }^{422}$ Such a decision is unknowable, and unprovable. A paradigmatic case here

\footnotetext{
${ }^{422}$ Facts drawn from Arndt v Smith, supra note 199 This case was rather anomalous. The SCC declined liability
} here; but, in the conceptually identical case of Hollis, found a causal link. It is more than likely that the SCC 
would be Hollis where proving causation flowing from the negligent failure to warn a doctor of risks in taking a particular medication depended on proving that the doctor would have passed on this warning to the plaintiff.

\section{(c) Returning to the Question: Are Dependency and Circular Causation Cases}

\section{Defined as the Limit in Clements?}

What is, ultimately not clear is whether the Supreme Court was limiting material contribution to risk to these categories. It does not appear that the Court was doing so, despite their particular selection of authorities.

The Court, rather than outlining an exclusive factual scenario that would trigger material contribution to risk, instead relied on simile and analogy. The Court did not, obviously exclude circular and dependency causation. In fact, drawing similes to existing cases, the Court referred to Walker — which is a classic dependency causation case-and Cook v Lewis - which is the paradigmatic circular causation case-as examples where material contribution to risk may apply.

Significantly, however, the Court did not end by stating that these examples may be representative of all of the cases that are likely to attract an analysis under material contribution to risk. Instead, the Court moved on to, after stating that but-for is the de facto test for causation:

Exceptionally, a plaintiff may succeed by showing that the defendant's conduct materially contributed to risk of the plaintiff's injury, where (a) the plaintiff has established that her loss would not have occurred "but for" the negligence of two or more tortfeasors, each possibly in fact responsible for the loss; and (b) the plaintiff, through no fault of her own, is unable to show that any one of the possible tortfeasors in fact was the necessary or "but for" cause of

parsed the decisions on the basis of the higher value given to doctors continuing to perform their jobs (Arndt) over the importance of manufacturers manufacturing (Hollis). 
her injury, because each can point to one another as the possible "but for" cause of the injury, defeating a finding of causation on a balance of probabilities against anyone. ${ }^{423}$

It seems impossible to imagine a circumstance that does not fit the circular or dependency label that but fits within this categorization. I certainly cannot imagine one. The 'finger-pointing' element of circular causation is at the core of (b), while the dependency causation is closely anchored in the "necessary or but-for cause" notation. This definition, while purporting to be open, appears to have such specificity that circumstances beyond circular and dependency causation are, ultimately, excluded. Even if, in the fevered imaginations of a legal philosopher, such a situation does exist, s46(2) $)^{424}$ limits material contribution to risk along artificial and, in some cases, manifestly unjust lines.

To illustrate, recall the three nurses hypothetical I first used in the introductory section of this thesis. Here, three nurses each separately give a patient a dose of medication, but negligently fail to note that they have done so. The first dose is beneficial, and the second fatal. Each nurse can state that but-for their negligence, the plaintiff would still have died, as the other two nurses would have ultimately administered the fatal doses. This three nurses hypothetical is a classic example of what is termed over-determined or oversubscribed causation. Such over-subscribed causation scenarios are relatively common. ${ }^{425}$

This three nurses hypothetical does not fit within the circumstances enunciated in paragraph 46(2) of Clements. The enunciation in Clements requires that each nurse was "each possibly in fact responsible for the loss"; ${ }^{426}$ and the plaintiff must show "that any one of the

\footnotetext{
423 Clements v Clements, supra note 1, para 46(2).

${ }^{424}$ Clements $v$ Clements, supra note 1.

425 See, for eg Richard W Wright, "Causation in Tort Law" (1985) 73:6 California Law Review 1735 at 1775 , 1777; Wright, supra note 10 at 1038 there, as an example, several otherwise forest regenerating fires combine to create an inferno that burns down a house.

426 Clements v Clements, supra note 1, para 46(2).
} 
possible tortfeasors in fact was the necessary or "but for" cause of her injury". ${ }^{427}$ The plaintiff in such a situation could not possibly meet such a test. The statement in Clements requires that the cause of the harm is isolated to one party, with the issue being proving which one. The latter quote uses the word 'necessary', preceded by 'any one of the tortfeasors'. ${ }^{428}$ The Supreme Court in Clements is thus requiring that only one of the tortfeasors' negligence was the actual—but not discoverable—cause of the plaintiffs harm. So, if applying the description in para 46(2) the unfortunate plaintiff cannot avail themselves to material contribution to risk; and has no chance of proving causation under but-for. Surely this cannot be what the Court in Clements intended. It seems that on the ordinary words of para 39 and 46(2) of Clements do indeed limit possible applications of material contribution to risk to patterns that demonstrate circular and dependency causation. The words of these paragraphs; the approving citation of a circular causation case specifically; ${ }^{429}$ a dependency causation case specifically; ${ }^{430}$ as well as mesothelioma; ${ }^{431}$ and the absence of a statement overruling Kay LJ in the BCCA seems to effectively limit material contribution to risk to circular and dependency causation scenarios. Despite the Court stating that they did not wish to be bound to circular and dependency causation scenarios, nonetheless, its characterisation in para 46(2) limits material contribution to such scenarios.

\section{(d) Reading Between The Lines-And Perhaps Filling In Some of My Own-To Find Material Contribution to Risk is Not Limited to Circular and Dependency Facts}

It does not seem to be so that the Supreme Court intended to limit material contribution to circular and dependency causation cases. Their phrasing, however, makes

\footnotetext{
427 Ibid.

428 Ibid.

${ }^{429}$ Ibid, para 45.

${ }^{430}$ Clements $v$ Clements, supra note 1.

431 Ibid, para 39.
} 
that the result. The discussion in the preceding paragraph, VII(3)(c), concentrated on the 'how' from Clements. This 'how' attempted to enunciated when, and on what facts, material contribution to risk can apply. But, as averred to the introductory section of this chapter, the 'how' and 'why' will face a Sisyphean struggle. The 'how' attempts to bound material contribution to risk to existing only in relation to certain fact patterns. The 'why' attempts to break down the neat curvature of these boundaries where doing so would be corresponds to the fairness principles enunciated in Hanke, Walker, Snell, and even Clements itself. There are two ways of showing that the 'how' in Clements does not exclude all fact patterns beyond circular and dependency causation from triggering material contribution to risk. The first is, concerned with the depths of corrective justice theory. It builds on substantial accounts of the substantive-remedial right conception, and finds that corrective justice- the 'why' in Clements — would support such a result. The second is a thankfully less elaborate elaboration on the residual concept of fairness, and the inherent policy based, plaintiff-centric paradigm of material contribution to risk.

\section{(i) Delving the Theoretical Depths of Corrective Justice: The 'Why' Does Not \\ Necessitate the Circular \& Dependency Causation Limitation}

Based purely on the 'how' enunciated in Clements, the patient in the three nurses scenario would not be able avail themselves to material contribution to risk. The patient's inability to isolate one potential plaintiff seems an unjust limitation.

Doubtlessly, it would stretch material contribution to risk past breaking point if a plaintiff was instead able to point to the wrongdoing of, for example, hundreds of 
companies for mislabeling a food item as 'healthy', as proof of their obesity related injury. ${ }^{432}$

Such an outcome is not one I advocate, nor is it likely that others would do so.

Instead, it seems that the statements of 'how' in Clements must be read in terms of the 'why' to apply material contribution to risk. Clements was explicit in making corrective justice as the root of its decision-making in causation. ${ }^{433}$ In Chapter IV of this thesis, I somewhat exhaustively buttressed these brief statements. Clements was clear in making corrective justice the 'why' that underpins its statements on 'how' material contribution to risk is to apply.

To elaborate on the 'why' here is to elaborate on corrective justice. No single theory can capture the entirety of the practical vagaries of a subject of law-but corrective justice does provide a fairly useful account of 'why' material contribution should apply in cases like, but not limited to, the over determined three nurses hypothetical.

Corrective justice is, despite common perception, perfectly compatible with expanding material contribution beyond the dependency and circular causation scenarios. ${ }^{434}$ Corrective justice emphasizes the bilateral nature of tort law, with defendants only responsible for harm they have themselves caused. ${ }^{435}$ This is a commonplace statement in looking at corrective justice in causation. However, it is all too easy to focus erroneously on the word 'caused'. Weinrib released a recent article that appropriately shifts the focus on the word 'harm'. ${ }^{436}$ Clements focuses on evidential uncertainty. In the three nurses case, there is no evidential uncertainty. All of the facts are known. Yet, corrective justice-the selected 'why'_for material contribution to risk would still apply.

\footnotetext{
432 Although, in Sindell v Abbott Laboratories, supra note 14 the Californian Court took a fascinating approach to this problem, by finding a causal link, and apportioning liability based upon the market share of the defendant. Such an outcome is not one I advocate and discuss here, but it is worth noting that these seemingly perverse factual situations can and do frequently arise in the real world.

433 On no less than seven occasions Clements v Clements, supra note 1 at 7, 12, 19, 12, 32, 37, 41.

434 Stapleton, supra note 229.

435 Snell $v$ Farrell, supra note 7 at 289.

436 Ernest J Weinrib, “Causal Uncertainty” (2015) Oxford Journal of Legal Studies 1.
} 
To begin the theoretical analysis, Weinrib's article looks at exactly what the 'harm' is within the structure of tort law. ${ }^{437}$ The causal process is not enlivened without the harm being suffered. Without the harm occurring, then to find a causal link and make a defendant liable would be to make that defendant liable for the caused by a third party. Weinrib looks to the actual structure of tort law; and, by going back to the breach stage of the inquiry, sees that corrective justice does not view 'harm' in the way that the casual reader sees 'harm'. The harm is the breach of the duty of care owed by the plaintiff to the defendant.

In the three nurses scenario, each nurse has breached their duty, thus occasioning the harm, and starting the causal chain. The actions of each of the nurses individually has its own agency. By each acting, each nurse individually denied the plaintiff their individual "power of proof" of the harm that he suffered. ${ }^{438}$ Thus, even though only the actions of only two of the three nurses was needed to cause the harm, each was causally involved in the destruction of the power of proof by the plaintiff to prove the injury they suffered. ${ }^{439}$ Weinrib's explanation of the nomenclature is useful here:

A single inclusive right with two aspects for the different stages of the parties' relationship is the only right there is. This right includes not only the physical integrity that is the object of what Rand calls 'the substantive right', but also the entitlement to a court award of monetary damages from anyone who wrongfully violates that physical integrity (Rand's 'remedial right'). ${ }^{440}$

The destruction of the power of proof is termed a substantive right by Weinrib and others. The injury suffered in the drug overdose of the plaintiff is what is termed a remedial right. Without a breach of both, corrective justice can not sustain the finding of a causal link. If, in the three nurses scenario, two nurses destroyed the plaintiff's

\footnotetext{
437 Ibid at 6.

438 Ibid at 8.

439 Ibid at 9.

440 Ibid at 10.
} 
charts — thus breaching the power of proof substantive right—with the third nurse giving a safe and beneficial medication dose, obviously, there is no breach of remedial right, and thus no damage could flow. ${ }^{441}$ Breach of this substantive right is harm; but it is not actionable per se. It must be actionable upon proof of loss- which is the remedial harm, in this hypothetical, the death of the plaintiff. If each nurse had acted negligently, but, through some freak occurrence, no harm was suffered by the plaintiff; then remedial right is not extant; and thus, no tort is possible.

Viewed as such, the three nurses scenario can find liability for each nurse under the material contribution to risk, and still reflect the bilateral nature of causation. Each nurse is being found liable for their breach of their duty, and is being made responsible for the causal results of this breach. The breach, and harm, is not only the death or suffering of the plaintiff. The harm is instead to the relationship between the plaintiff and the defendant. Each defendant caused a substantive harm to the plaintiff by occluding their potential share in the remedial harm that was eventually suffered. This characterization of the harm and causation the three nurses scenario strongly upholds corrective justice. Each nurse is fundamentally liable only in terms of their relationship to the plaintiff. There has, in Weinrib's corrective justice, been an injury suffered that was caused by each of the defendants. There is, however, an evidentiary gap as to which nurse breached the remedial right of the plaintiff-but leaping this evidentiary gap is precisely the purpose of unorthodox causation generally, and material contribution to risk specifically. ${ }^{442}$

This perspective has the advantage of avoiding the need to resort to fictions of joint and several liability; ${ }^{443}$ nor are any of the defendants responsible for harm that is not theirs.

441 This is precisely what was stated in Joseph Brant Memorial Hospital v Koziol, [1978] 1 SCR 491.

442 Jane Stapleton, supra note 6.

${ }^{443}$ As was seen in Summers v Tice, supra note 210. 
Causation has never regarded there to be a necessity between wrongdoing and a proportionate outcome. One person may negligently release gallons of cyanide, and cause no tortious harm; while another may negligently release a thimbleful; and be liable to thousands. ${ }^{444}$

To turn from extemporizing, and return to Clements, corrective justice does indeed support material contribution to risk being triggered by fact patterns that are resemble neither circular causation nor dependency causation. Clements insists on corrective justice throughout: surely this insistence goes some way to not limiting liability in a way that is contrary to this rationale.

\section{(ii) (in)Justice, Plaintiffs \& Policy}

On first glance, it was a curious choice for the Court in Clements to not overturn the cases on material contribution to risk that came before it. Each case restated the test in a manner that was rather confused and confusing: ${ }^{445}$ it would seem logical that to clear up confusion, the Supreme Court in Clements would seek a clean slate, and write the principle anew. It did not do so, and was correct in doing so.

The cases that came before Clements did not have a clear enunciation of 'how' material contribution to risk could be triggered. They did, however, have useful enunciations of the 'why'.

Walker "created an exception with entirely uncertain parameters"; ${ }^{46}$ but did rightly emphasize that the but for test could be replaced by the material contribution test where the

${ }^{444}$ The common law has had such an (exceptional) rule for nearly a century and half Rylands v Fletcher, [1868] 1 UKHL (House of Lords).

${ }^{445}$ Especially Athey v Leonati, supra note 1; Walker Estate v York Finch General Hospital, supra note 1; Resurfice Corp v Hanke, supra note 1.

446 Cheifetz, supra note 325 at 204. 
but-for test "operated unfairly (by) leaving legitimate plaintiffs uncompensated". ${ }^{447}$ It is worth noting that the Court said uncompensated, not undercompensated. Their interests were not total compensation; but rather any form of vindication.

Resurfice stated that, where resorting to but-for causation would "offend basic notions of fairness and justice", ${ }^{448}$ material contribution to risk may be available as a principle. Clements $^{449}$ agreed substantially with the BC Court of Appeal reading of the material contribution to risk, which applied this exact wording ${ }^{450}$ from Resurfice.

The Court in Clements quoted Chambers v Goertz ${ }^{451}$ in defining its classification of material contribution to risk:

(M)aterial contribution does not signify a test of causation at all; rather it is a policy-driven rule of law designed to permit plaintiffs to recover in such cases despite their failure to prove causation. In such cases, plaintiffs are permitted to "jump the evidentiary gap" ... That is because to deny liability "would offend basic notions of fairness and justice" Hanke v. Resurfice Corp., para. $25 .^{452}$

This quotation again emphasized material contribution to risk as a shield for plaintiffs against injustice in the causal process.

It would seem perverse for the Court in Clements to, in one moment pursue a persistent citation of authority conceiving of material contribution to risk as a shield against injustice in the causal process; and on the other, deny the application of material contribution to risk in cases such as the three nurses hypothetical. To deny such an

${ }_{447}$ Walker Estate v York Finch General Hospital, supra note 1, paras 87-88. Walker Estate v York Finch General Hospital, supra note 3, paras 87-88.Walker Estate v York Finch General Hospital, 1 SCR 647 (2001), paras 87-88. Walker Estate v York Finch General Hospital, supra note 1, paras 87-88.W alker Estate v York Finch General Hospital, supra note 295, paras 87-88. Walker Estate v York Finch General Hospital, supra note 1, paras 87-88.

448 Resurfice Corp v Hanke, supra note 1, paras 25-26.

${ }^{449}$ Clements v Clements, supra note 1, para 45.

${ }^{450}$ Clements v (Litigation Guardian of) Clements, supra note 223, paras 63-64.

${ }^{451}$ MacDonald (Litigation Guardian of) v Goertr, supra note 368, para 17.

452 Clements v Clements, supra note 1, para 14 (Footnotes omitted). 
application would, for the plaintiff, obviously offend these same basic notions of fairness and justice. ${ }^{453}$ There is no countervailing 'policy-driven' rationale to deny the plaintiff recourse to material contribution to risk. ${ }^{454}$ Throughout the varied discussions of material contribution to risk, the plaintiff has consistently been the paradigm through which the Canadian jurisprudence has viewed material contribution to risk. The UK approach seems to have largely shed its corrective justice viewpoint, replacing it with a defendant-centric one, where optimal defendant deterrence is paramount. ${ }^{455}$ This approach is not the Canadian one. Injustice to the plaintiff, however nebulous that may be as a concept, ${ }^{456}$ the 'why' in Clements applying material contribution to risk. The Court consciously preserved this element in the cases that came before it, and seemed targeted in its citations to underscore this point. Despite the-I argue unwittingly_narrow wording in paras 39 and 46(2), the Court appeared to both countenance and directly envisage that circumstances beyond that it could imagine could exist, and in those situations, if there was manifest injustice to the plaintiff by sticking to causal orthodoxy, courts were free to pursue material contribution to risk.

The oversubscribed causation example illustrated by the three nurses hypothetical surely is such an occasion. By their persistent citation of fairness and justice in regards to the plaintiff, it is fairly clear that the Court in Clements did not intend to limit material contribution to risk to apply only to circular and dependency causation scenarios. To regard the view of Clements as so limited would be to read their wording in para 39 and 46(2) on its literal terms — this would be reading only the 'how' with no reference to the 'why' material contribution to risk can be applied. Clements is not so limited. The paradigmatic examples-

\footnotetext{
453 Resurfice Corp v Hanke, supra note 1, para 25.

454 MacDonald (Litigation Guardian of) v Goertr, supra note 368.

455 See especially Barker v Corus, supra note 246; Compensation Act, supra note 292, s 2; UK Department Of Constitutional Affairs, supra note 296, para 13.

456 Weinrib, supra note 436 at 10.
} 
the how-will remain cases that are circular and dependency causation scenarios. But, these cases are not the boundary, and in exceptional cases, material contribution to risk can also be triggered by the 'why' when the applying only the 'how' criterion would force resort to butfor, and the manifest injustice that may entail.

\section{Question 3: Surely Material Contribution To Risk is Not Limited to Multiple}

\section{Tortfeasor Cases?}

There was a specific reference to the Sienkiewicz decision in Clements, where the Court stated unequivocally that it would not follow such an approach. What is not clear, however, is whether the Court in Clements was stating that it would not consider itself bound to apply material contribution to risk in all mesothelioma cases; or if the Court was stating that it would not apply material contribution to risk in single tortfeasor scenarios. The conclusion is certainly one; and perhaps both. The Court stated:

The only case to apply a material contribution to risk approach to a single tortfeasor is Sienkiewicz. A plaintiff suffering from mesothelioma had only been exposed to asbestos from a single negligent source and on the trial judge's findings, "but for" causation could not be inferred. The United Kingdom Supreme Court took the view that it was bound by precedent to apply a material contribution to risk approach in all mesothelioma cases... In my view, nothing compels a similar result in Canada, and thus far, although Sopinka J.'s remarks in Snell (quoted above at para. 20) do not preclude it, courts in Canada have not applied a material contribution to risk test in a case with a single tortfeasor. ${ }^{457}$

The Court makes mention of single tortfeasors in both the first and last sentences, with the discussion of Sienkiewicz placed in between. On first reading, it is not clear if the finding in Sienkiewicz is marginalised, or if single tortfeasors are excluded as well. The close reading of Clements reveals that the Court was not attempting to exclude single tortfeasor

457 Clements v Clements, supra note 1, para 42. 
actions; but was simply attempting to preclude the perverse result in Sienkiewic ${ }^{458}$ from being imported to Canadian jurisprudence.

It seems that, on closer reading, that the Court did indeed exclude single tortfeasor cases. The logic, behind this, is, however, more than a little puzzling. Even Sienkiewicz itself, Lord Dyson noted that there seemed to be no normative basis for this view, ${ }^{459}$ and certainly no such exclusion in Fairchild. ${ }^{460}$

The Court in clearly justified that the principle of law flowing from Seinkiewicz. was not the law of Canada, ${ }^{461}$ albeit their phrasing was "without valid explanation". ${ }^{462}$ Sienkienicz was, for the UK, the high-water mark for material contribution to risk. It seems a somewhat bizarre, and thoroughly anomalous case. In the UK, the background risk of contracting mesothelioma is one in 24 million. The negligent exposure by Greif had only increased the risk of contracting exposure in Ms Costello (one of the two plaintiffs) to one in 29 million. The vast majority of the discussion focussed on the doubling of the risk doctrine, which in not part of the Canadian law. Furthermore, the counsel for the defendant made a very odd concession that, in cases of multiple exposure, but-for causation would not apply, and material contribution to risk would. This concession mirrors the similar, deeply confused statement $W$ alker, which took significant work in later cases to marginalise. The Court in Sienkiewicz saw itself as bound to apply material contribution to risk to all mesothelioma cases, forcing the somewhat anomalous result, where Greif was compelled to, under statute, ${ }^{463}$ be

\footnotetext{
458 See Stapleton, Jane, supra note 5; Turton, supra note 295.

459 Sienkiewicz, Greif (UK) Ltd, supra note 3, para 212 (Lord Dyson).

460 Stapleton, Jane, supra note 5 at 222.

461 Clements v Clements, supra note 1, para 42.

462 Cheifetz, supra note 16 at 2.17.

463 Compensation Act, supra note 292.
} 
jointly and several liable, despite the frank admission that the vast majority of the exposure was not within the defendant's control.

The Court in Clements seems to have made a conscious mode to exclude the outcome in Sienkiewicz. Throughout the judgment the Court emphasised that there needed to be at least two tortfeasors for material contribution to risk to potentially apply. ${ }^{464}$ The Court did, however, make a particularly strange notation in the end of the para 42, where, it bears reminding, that the Court explicitly excluded Sienkiewicz: In my view, nothing compels a similar result in Canada (having an application of material contribution to risk to a single tortfeasor case), and thus far, although Sopinka J.'s remarks in Snell (quoted above at para. 20) do not preclude it, courts in Canada have not applied a material contribution to risk test in a case with a single tortfeasor. ${ }^{465}$

To state that an authoritative judge in a seminal case in Canadian causation did not preclude the possibility of a single tortfeasor material contribution to risk case; and then append a statement that this has not happened would be strange on its own. Adding to this the fact that material contribution, to either single or multiple tortfeasor cases, has never been applied in Canada, makes this statement all the more strange.

The result in Sienkiewicz, was indeed perverse, with the highest court in the UK considering itself bound to follow the law to a vexing outcome. The Court in Clements was clear in stating that Canadian courts were not thusly bound; and, I argue, correct in stating that Sienkiewicz should not stand as good law in Canada. But, on the language of the Court, it is quite far from clear that in this section the Court intended to exclude single tortfeasor cases altogether. Rather, it seems that

464 Clements v Clements, supra note 1, para 42.

465 Ibid at 42. 
they were ambivalent to such an approach—but were appreciably leery of the result in Sienkiewicz — and as a result their language on excluding single tortfeasors here was muddled.

The language of the Court throughout the rest of the judgment, however, appears to persistently exclude the possibility of a single tortfeasor trigger to material contribution to risk.

Unlike the preceding section, where a close reading of the entirety of the decision in Clements lead to the conclusion that the Court would prefer to not limit triggers to circular and dependency causation cases, such a reading is not available here. Despite the ambivalence at the end of paragraph 42, the Court consistently, and persistently referred to the need to have more than one tortfeasor. There is no other interpretation available, other than that the Court was explicitly attempting to exclude single torfeasor cases from triggering material contribution. What is available, however, is a demonstration of the lack of underlying logic to this view.

\section{(a) Arguing for A Marginalization Before It Takes Shape: Eradicating the Bar on Single Tortfeasor Cases Triggering Material Contribution to Risk}

In Patterson, ${ }^{466}$ one of the cases joined to Barker, the tortfeasors were responsible for only 18 per cent of the exposure to risk. Two other companies were identifiable as wrongdoers. These companies were responsible for the remaining 82 per cent of the risk exposure. However, these two companies were insolvent: making it impossible to bring them as tortfeasors. The presence of two, rather than one tortfeasor at trial was a pure happenstance.

\footnotetext{
466 Smiths Docks Ltd v Patterson, supra note 276.
} 
The correct reading of Clements is that the Court, despite their ambivalence towards the issue when excluding Sienkiewicz, did persistently in their writing exclude single tortfeasor cases as potentially being a trigger to material contribution to risk. This outcome, however, seems to have little, if any logical or normative underpinning. By parsing cases in which there were two negligent wrongdoers who are both available as a tortfeasor; and cases where there were two negligent wrongdoers, only one of which is available as a tortfeasor is, a baffling distinction.

Material contribution to risk will largely only apply in cases where the negligent parties are independent ones: if they were conjoined in purpose, then orthodox but-for causation would have no issue in combining the actions of the defendants to devise a causative link.

To illustrate the lack of logic in limiting material contribution to risk to multiple tortfeasor cases, three hypotheticals may suffice. In the first hypothetical, plaintiff $\mathrm{A}$ is exposed to a substantial amount of asbestos, resulting in mesothelioma. The exposure was in equal amounts by defendants X, Y and Z. Due to other similar litigation, Defendant $\mathrm{Z}$ is now insolvent, so cannot be joined; but defendants $\mathrm{X}$ and $\mathrm{Y}$ are available as tortfeasors. Here, plaintiff A could likely trigger material contribution to risk, and succeed in proving a causal link.

In the second hypothetical, plaintiff B is also exposed to a substantial amount of asbestos, resulting in mesothelioma. The exposure is also in equal amounts, by defendants 1, 2, 3, 4, 5, 6, 7, 8 and 9. Defendants 3-9 are also insolvent and unavailable as tortfeasors. Plaintiff B could likely trigger material contribution to risk, and succeed in proving a causal link. 
The third and final hypothetical, plaintiff $\mathrm{C}$ is indeed also exposed to a substantial amount of asbestos, resulting in mesothelioma. Forty per cent of the exposure was due to the negligence of defendant (i); with the remaining sixty per cent due to the negligence of defendant (ii). Due to similar litigation, defendant (ii) is unavailable to be joined as a tortfeasor. Here, despite defendant (i) being responsible for more of the contribution to risk than the defendants in the first two hypotheticals; plaintiff $\mathrm{C}$ is unable to trigger material contribution to risk because there is only one tortfeasor. It seems that, due to factors entirely beyond their knowledge, control and responsibility; plaintiffs $\mathrm{A}$ and $\mathrm{B}$ were beneficiaries of random luck, and prove a causal link; and plaintiff $\mathrm{C}$ is not such a beneficiary, and thus cannot prove a causal link. To read Clements to deny Plaintiff $\mathrm{C}$ the use of material contribution to risk would, to refer back to Resurfice, "offend objective notions of fairness and justice". ${ }^{467}$

Unlike, however, the persistently ambivalent language used in the preceding section of this thesis, where the Court seemed to unknowingly trap themselves into defining the trigger as only arising in circular and dependency causation cases, here, the Court was explicit throughout their writing that the 'how' for triggering involves more than one tortfeasor. I assert that to do so is to err. Instead, what seems to be more logically and conceptually sound is to permit single tortfeasor cases, as long as there were other wrongful sources of harm. To do so opens a whole new Pandora's box of issues. The following questions seem inescapable:

1. What is the bottom threshold? Surely the last defendant standing, responsible for an miniscule amount of the liability shouldn't be left facing liability for the insolvency of others?

\footnotetext{
${ }^{467}$ Resurfice Corp v Hanke, supra note 1, paras 35-36.
} 
2. What of contributory negligence? If the defendant was liable only for part of the material contribution to risk, and the plaintiff the rest, surely this is problematic?

3. What of innocent sources? If the defendant is responsible for only part of the contribution to risk, but the remainder was attributable innocent or non-tortious sources, again, should the defendant be liable for exposure beyond his own?

These questions seem initially vexing, but each have a common thread, so much so that they can all be answered together. The concern inherent in each case is that the defendant will become liable for harm that is not causally connected to them. To foreshadow the argument that I made in the following chapter, a defendant never simply liable, they are always liable for something. The fear that runs through each question is based upon the current law in the UK-which has been clearly shown to not be the law of Canada. In the UK, liability in all material contribution to risk cases is joint and several. ${ }^{468}$ So, in each of these situations, the defendant would indeed feel aggrieved: like in Sienkiewicz, despite the negligent exposure increasing the risk from one in 24 million to one in 29 million, the defendant had to pay damages in full. This is not the law of Canada.

Canada is free to devise their own apportionment rules. In terms of the trigger that is discussed here, there is no logical or theoretical reason exclude the single tortfeasor case from triggering material contribution to risk. As long as the defendant is not being compelled to be responsible for damages that are beyond their responsibility, corrective justice is not vitiated. If material contribution to risk is to be

468 Compensation Act, supra note 292, s 2. 
an unorthodox causal process that is to be applied in cases where to do not do would create injustice, ${ }^{469}$ the exclusion of single tortfeasor cases as triggers must be removed. Despite the persistent attempts to exclude single tortfeasor cases, Clements insistence on there being more than one tortfeasor available should be read down.

\section{4: Looking to the Systemic effects of Material Contribution to Risk in Unorthodox Causation: It Is a Support, or a Cannibal?}

Whither the remainder of unorthodox causation? As noted at length in section V of this thesis, material contribution to risk is not anomalous in being an unorthodox test for causation. Other unorthodox causal processes exist. Cookv Lewis crafted what I term burden shifting but-for. Hollis v Birch was the clearest example of the learned intermediary rule, which was what I termed standard shifting but-for. The question I ask here is: do these other unorthodox causal processes exist any longer?

Clements expressed unwitting approval for dependency and circular causation as the nigh-on exclusive circumstances that can trigger material contribution to risk. What is unclear, and a rather interesting question, is: has material contribution to risk cannibalized the remainder of unorthodox causation? To put it another way, have the unorthodox tests been displaced by material contribution to risk?

Cook v Lewis from 1948 is the paradigmatic case for what I term unorthodox burdenshifting but for. However, the Court in Clements cited Cookv Lewis as a classic case that may attract material contribution to risk analyses. Cook is a classic circular causation case; as are the UK mesothelioma cases to which the Court referred. ${ }^{470}$

\footnotetext{
${ }^{469}$ See Resurfice Corp v Hanke, supra note 1; Walker Estate v York Finch General Hospital, supra note 1, para 88.

470 Barkerv Corus, supra note 246; Fairchild v Glenhaven Funeral Homes, supra note 69.
} 
Equally, the Court in Clements cited Walker, a case that would classically attract the unorthodox standard-shifting but for causal analysis, as a case that may also attract material contribution to risk. Walker is a classic dependency causation case.

What then, of these two unorthodox causal processes? On the most minimalist interpretation, the Court has enunciated that the circumstances that would attract these unorthodox causal processes could also attract material contribution to risk. On the maximalist interpretation, the Court has cannibalized these unorthodox tests, leaving material contribution to risk as the only unorthodox causal test surviving. The following section analyses what the current statement of material contribution to risk has done in relation to these unorthodox causal tests. The analysis is particularly illuminating because it shows exactly how exceptional the Supreme Court characterized the application of material contribution to risk.

\section{(a) A Truly Exceptional Principle}

If the Supreme Court had consciously wished for material contribution to risk to displace the unorthodox causal tests classically used in Cook and Walker, they would have been explicit in making such a statement. What the Court in Clements and also in Snell, Walker, Athey and Resurfice was explicit in stating was that material contribution to risk was an exceptional test for causation. In each case, and, ultimately every other negligence case in Canadian jurisprudence, has been clear in stating is that but-for causation is the de facto test for causation. These statements have operated as a binary — with all of the but-for causal processes on coded as a zero, and material contribution to risk coded as one. But-for tests are the de facto, with material contribution to apply only where the application of these tests fails in the manner enunciated in Clements. 
Bear in mind here that the of terming of dependency shifting and burden shifting as different tests, rather than muddled exceptions to the normative but-for test, is a distinction of my own crafting. When the Supreme Court refers to but-for causation, they fold in these two unorthodox causal processes into the general nomenclature of 'but-for'. The Court in Clements stated "The possibility of material contribution as an exceptional substitute for "but for" causation has arisen in a variety of contexts involving multiple tortfeasors." ${ }^{\text {471 }}$ Equally, in Resurfice, the Court stated that in "special circumstances" the "exceptional" principle of material contribution to risk could be triggered. ${ }^{472}$

\section{(b) Permissive Language}

The point that is somewhat laboriously made here is the marked marginalization of material contribution to risk. The Court persistently uses permissive, not mandatory language in their enunciation of when material contribution to risk applies. In Resurfice, the Court stated:

One situation requiring an exception to the "but for" test is the situation where it is impossible to say which of two tortious sources caused the injury, as where two shots are carelessly fired at the victim, but it is impossible to say which shot injured him: Cook v. Lewis, [1951] S.C.R. 830. Provided that it is established that each of the defendants carelessly or negligently created an unreasonable risk of that type of injury that the plaintiff in fact suffered (i.e. carelessly or negligently fired a shot that could have caused the injury), a material contribution test may be appropriately applied. ${ }^{473}$

The Court in Resurfice was stating that a court may apply material contribution to risk in cases like Cookv Lewis. To build on Clements it seems that even in paradigmatic

471 Clements v Clements, supra note 1, para 17.

472 Resurfice Corp v Hanke, supra note 1, paras 24-25.

473 Ibid, para 27 (Emphasis added). 
circular causation cases like Cook or classic dependency causation cases like Hollis, courts are free to apply material contribution to risk only if the 'why' is also met.

\section{(c) 'How' and 'Why' Are Cumulative}

If Cook v Lewis, Hollis, or Walker was heard today, then material contribution to risk would only be applied if the 'why' was also met. The circular and dependency cases that the BC Court of Appeal explicitly applies ${ }^{474}$ — and the Supreme Court avers to ${ }^{475}$ —are not the exclusive triggers for material contribution to risk. By applying the unorthodox causal process flowing from Cook, a similar case heard today would be able to satisfactorily apply the but-for test, albeit the unorthodox burden shifting but-for version, without triggering the 'why' of injustice to the plaintiff.

In the cases that the Court in Clements cites as classic ones that may classically defined the 'how' for triggering material contribution to risk, the existing unorthodox causal tests would allow the application of but-for for in a way that would avoid the injustice that is the essence of the 'why'. So, despite explicitly referring to Cook v Lewis throughout their considerations on material contribution to risk; even if a case identical to Cook v Lewis was heard today, it still would not trigger material contribution to risk. This causal process rightly applied would be the one applied in Cook v Lewis — unorthodox burden shifting but-for. The plaintiff would suffer no injustice in such a case, because the unorthodox test of causation would preclude the injustice that the Supreme Court enunciated as the 'why', because the plaintiff would indeed be able to prove causation.

It seems that the Supreme Court has not excluded the unorthodox causal processes distilled in Cook v Lewis and Hollis. Unorthodox burden shifting and standard shifting but-for

${ }^{474}$ Clements v (Litigation Guardian of) Clements, supra note 223.

475 Clements v Clements, supra note 1, para 45. 
survive- they have not been displaced or cannibalized by the now extant unorthodox causal principle of material contribution to risk. What this goes to demonstrate is the sheer exceptionalness of material contribution to risk. The Court in Clements was not stating that, if heard today, Cook v Lewis or Walker would trigger material contribution to risk. What they were instead saying was that if a case similar to these cases was heard today, it would only trigger material contribution to risk if there would be the an inherent injustice in not applying but for or any of its unorthodox descendants. Klar, and many others, conceive of the causal processes flowing from Cook $v$ Lewis and Hollis to be exceptions. Thus, material contribution to risk is an exceptional exception - it applies only when the existing unorthodox causal tests fail. It is part of the causal array: but is contingent upon the rest of the array failing to achieve a just outcome. ${ }^{476}$

Once the pruning back of the existing concepts occurs, it seems inescapable that the Court in Clements has prescribed an exceedingly limited trigger for material contribution to risk. Only when the 'how' is triggered by a circular or dependency (or similar) fact pattern; and applying any of the orthodox or unorthodox processes that exist to avoid in justice still leads to injustice to the plaintiff, will a court be correct to apply material contribution to risk. This is indeed an exceptionally limited application of material contribution to risk. Despite fact often being stranger than fiction, it seems an exceptionally small number of cases could potentially trigger material contribution to risk. The trigger for material contribution to risk is, ultimately in Clements a cumulative one: it must bear a similarity to the criteria and examples enunciated by the Court as 'how' triggers; and it must not be covered by existing causal tests. Contrary to what seems intuitive, the other causal processes mentioned in

\footnotetext{
476 Vaughan Black, supra note 193.
} 
Clements have not been cannibalized. They are alive and well; with their presence determining material contribution to risk to truly be an exceptional principle.

\section{Drawing it all Together: Re-Enunciating the Trigger}

The trigger for material contribution to risk is, at once, more and less restrictive than it seems. Clements did not define a trigger for material contribution to risk in clear or simple terms. There was no simply enunciation that stated but-for causation analyses could be replaced by material contribution to risk in specific circumstances. The current trigger is a deeply limited and somewhat confusing one. Any attempt to reconstruct the trigger in a clearer manner must contain the following points:

1. Material contribution to risk may apply in circular and dependency scenarios, as seen in Cookv Lewis and Hollis, respectively; and

2. Dependency and circular causation scenarios are not the totality of factual scenarios that trigger material contribution to risk, but are instead suggestive of the types of cases that may trigger its application; and

3. All cases that may trigger material contribution to risk must have more than one defendant available to be joined as tortfeasor; and

4. Material contribution to risk will only apply when the facts of the case will make the use of either orthodox or un-orthodox but-for causal processes will still result in an injustice to the plaintiff.

The first three points pertain to the 'how' material contribution to risk can apply.

The fourth point pertains to the 'why'. Only when the circular, dependency or similar causal fact pattern appears; with multiple tortfeasors; and where application of any but-for causal 
process will result in injustice to the plaintiff will material contribution to risk be triggered. A clearer definition of the law on when a material contribution to risk will be triggered is:

1. "material contribution to risk will only be triggered:

a. when the plaintiff shows that their loss would not have occurred but for the negligence of two or more tortfeasors, each of whom is possibly actually responsible for the loss; and

b. when factual circumstances that resemble the circular causation facts seen in Cookv Lewis or dependency causation facts seen in Walker; and

c. to rely on existing but-for based causal processes will result in manifest injustice to the plaintiff

2. Exceptions to 1(a) may well exist:

a. but any such application must be even more exceptional than the already exceptional nature of this test; and

b. such an exception must be motivated by $1(\mathrm{c})$

This definition of the trigger is a somewhat clearer characterization of the trigger than the one in Clements, and is a far more clearer one than the one seen in the cases before Clements. Parts 1(a), 1(b) and 2(a) pertain exclusively to the 'how' material contribution to risk can be triggered; parts 1(c) and 2(b) pertain exclusively to the 'why' it can be so triggered. Only when viewed as conjunction of both the 'how' and the 'why' can the trigger to material contribution to risk be defined. 


\section{Summary: Triggers}

This section has closely interrogated the enunciation of the trigger for material contribution to risk flowing from the majority decision in Clements. The law of Canada is clearly separate from that of the UK: the UK restrictions on mesothelioma do not apply to Canada. The Court in Clements on first glance may well have limited material contribution to risk to circular and dependency cases; but a close reading of the judgment, and associated judgments, finds that these cases are sufficient, but not necessary to trigger the 'how' element of material contribution to risk. The Court did, however, explicitly limit the application of material contribution to risk to cases that have at least two tortfeasors; but I have argued that this should not be so-and that this part of the current trigger should be read down. Finally, this section revealed how truly limited material contribution to risk is as a principle. The 'how', best (but not exclusively) demonstrated by circular and dependency causation cases will still not trigger material contribution to risk unless the 'why' of manifest injustice is also present. As a result, the existing unorthodox causal processes that already apply in most circular and dependency causation cases are preserved: showing material contribution to risk to truly be deeply exceptional. 


\section{Hic Sunt Dragones: Working Through Apportionment}

On ancient maps, in uncharted waters known to be particularly dangerous, cartographers would mark these areas with 'Hic Sunt Dragones': literally, here be dragons. Such a notation is equally appropriate in considering apportionment in material contribution to risk. No defendant is ever simply liable; they are always liable for something. Under but-for causation, there is a clear enunciation of what this 'something' is. Extant apportionment rules define when the extent of liability for defendants under the but-for causal tests. Material contribution to risk, despite being but one of several unorthodox causal tests, is the first causal process not anchored to the fictions that anchor but-for causation and its associated apportionment rules. But-for causation operates on the necessary fiction that he defendant 'caused' the harm to the plaintiff, and that they are thus liable for all of the relevant harm. ${ }^{477}$ Material contribution instead regards the defendant's causal involvement as only part of the cause of the plaintiffs harm. The all-or nothing compensation approach taken in most of but-for cause ${ }^{478}$ may well not be appropriate to material contribution to risk cases. Choosing one apportionment rule or another requires a thorough elaboration of the apportionment options; their advantages and liabilities; and a careful selection of which apportionment rule_-or rules_-will best reach the goals of the law of negligence that have been enunciated in chapter IV. Apportionment in material contribution to risk has not been discussed judicially; and has only barely been discussed in the academic literature. This section makes an original contribution to both by determining which apportionment rule reflects the nature of material contribution to risk causal inquiry.

\footnotetext{
477 Unless in particular and enunciated exceptional areas Gerald Boston, "Apportionment of Harm in Tort Law: A Proposed Restatement” (1995) 21:2 University of Dayton Law Review 267.

478 S. Green, supra note 13 at 161.
} 


\section{A The Apportionment Position under the But-For Causal Tests}

\section{Single Tortfeasor But-For}

Under but-for causation, a defendant is typically liable for the entirety of the harm they are causally connected to. ${ }^{479}$ When a defendant is found to have caused the plaintiff's harm, the defendant is liable for those injuries. The Court in Snell expressed the causal relationship in this regard accurately: "Causation is an expression of the relationship that must be found to exist between the tortious act of the wrongdoer and the injury to the victim in order to justify compensation of the latter out of the pocket of the former". ${ }^{480}$ The relationship between the defendant and plaintiff is, in but-for, one that once breached, aims to restore the plaintiff to position that they would have been but for the negligence of the defendant. Klar states "having the required elements of a negligence action, the plaintiff will be entitled to full compensation for the injuries suffered". ${ }^{481}$ In the ordinary but-for case, the injuries that the plaintiff seeks compensation for is the deleterious—-generally physical—harm they suffered. In Snell, the harm suffered was the blindness in one eye; in Clements it was the permanent disability suffered in the motorcycle crash; in Walker it was the HIV contracted through the blood donation. In a but-for case, the norm is to compensate the defendant for that harm in full. Exceptions do, however, exist.

In a single tortfeasor case, the most significant exception is that of contributory negligence. ${ }^{482}$ In contributory negligence, the damages of the plaintiff are reduced accordingly. An example would be where a plaintiff passenger fails to wear a seatbelt in a negligent car accident. The actions of the negligent party were obviously the cause of the

\footnotetext{
${ }^{479}$ Klar, supra note 11 at 544.

480 Snell v Farrell, supra note 7.

481 Klar, supra note 11 at 531.

482 NP Gravells, “Three Heads of Contributory Negligence” (1977) 93 LQR 581.
} 
injury; but the omission to wear a seatbelt constitutes a relevant contribution to that negligence. ${ }^{483}$ Froom v Butcher, a UK case, sums up the common law well: "Negligence is a man's carelessness in breach of duty to others. Contributory negligence is a man's carelessness in looking after bis own safety." ${ }^{484}$ This is, of course, an accurate common law statement. Each Canadian province has its own legislation on contributory negligence: ${ }^{485}$ but this thesis aims to provide a contribution to the literature that is not tethered to the phrasing of any one jurisdiction. In cases of contributory negligence, the individual action of the plaintiff in terms of his own carelessness means that the damages award would be reducible by whatever portion of his loss was attributable to his contributory negligence.

\section{Multiple Tortfeasor But-For}

The simplicity of single tortfeasor but-for vanishes in cases of multiple defendants. ${ }^{486}$ The bipolar nature of corrective justice demands that the responsibility flowing from the defendant to the plaintiff is limited to harms the defendant has themselves caused. ${ }^{487}$ In multiple tortfeasor cases, each defendant is considered independently. Under but-for, a plaintiff cannot validly argue that the actions of a series of unconnected defendants caused their harm. ${ }^{488}$ That is not how corrective justice characterizes causation. If a series of unconnected defendants each negligently placed a stone on a bridge until that bridge collapsed under the weight, but-for causation would have to look at each defendant independently, in terms of their relationship to the plaintiff, and ultimately conclude that each defendant was not the cause of the plaintiff's harm. But-for causation is all-or-nothing. But-for is a binary: either

483 Bulmer v Horsman, [1987] 42 CCLT 220 at 223.

484 Froom v Butcher, [1975] 3 WLR 379 at 383.

485 See, for example Negligence Act, RSBC 1996 c 333 (British Columbia) [Negligence Act].

${ }^{486}$ See Andrew G Celli Jr, "Toward a Risk Contribution Approach to Tortfeasor Identification and Multiple Causation Cases” (1990) 65 NYUL Rev 635.

487 Whiten v Pilot Insurance Co, supra note 139, para 154; Weinrib, supra note 67.

488 See, for a concise statement of this difficult reality: Thompson v Smiths Shiprepairers (North Shields) Ltd, [1984] 405 QB , paras 448-449. 
the defendant will be considered to be the cause of the plaintiff's harm, and will be responsible for all of the harm; or he will not be the cause, and will be responsible for none of it.

Two substantial exceptions apply. Firstly, joint tortfeasors are liable globally for the actions of each and every other tortfeasor, at both the causation and apportionment stage. Secondly, where the injury that is suffered is divisible, the binary of the 100 per cent or 0 per cent liability position is replaced by one reflecting the divisible nature of the harm.

\section{(a) Joint and Several Liability}

In cases of joint and several liability, the relationship is not termed as a purely binary one between the plaintiff and each particular defendant. Due to the particular circumstances of the case, joint and several liability allows for each defendant to be causally responsible and liable for the damages of his own actions and the actions of his fellow tortfeasors. Glanville Williams, the leading authority on liability rules, applies his definition thusly: "the term 'joint tortfeasor is, essence, well understood. Two or more tortfeasors are join tortfeasors (a) where one is the principal of or vicariously liable for the other, or (b) where a duty imposed jointly upon them is not performed, or (c) where there is a concerted action between them to a common end". 489

The first category can be demonstrated by an employer being liable for the actions of their employee. The second could be demonstrated by one defendant being hired to design a bridge, and the other being hired to build such a bridge- - both have a jointly imposed duty to ensure the bridge is safe. The third category can be seen in a case where two defendants were racing on a highway, and one driver killed a bystander. ${ }^{490}$

\footnotetext{
${ }^{489}$ Glanville Williams, Joint Torts and Contributory Negligence (London: Stevens \& Sons, 1951) at 1. 490 Ibid at 10 .
} 
In each of these cases, the actions of each of the defendants removes the corrective justice view that each is viewed only in terms of their individual responsibility to the plaintiff: their responsibility fuses and becomes cumulative with that of the other defendants. As a result, causation is viewed globally between the two parties: a Court would view the causal contribution of both racers to see if the death of the bystander was relevantly so caused. ${ }^{491}$ In such a case, even if one of the racers was insolvent, the plaintiff could recover in full from the other.

\section{(b) Divisible Injuries}

In cases of divisible injuries, the responsibility of the defendant is viewed more closely in terms of what harm they caused. ${ }^{492}$ Say, for example, defendant A negligently hits plaintiff $Z$ with his car, breaking his legs, causing $\$ 100,000$ in damages. Then, while Plaintiff $\mathrm{Z}$ lies there immobile, defendant B negligently runs over his hands, breaking them, causing $\$ 25,000$ in damages. ${ }^{493}$ The injury suffered by plaintiff $Z$ is, here, a divisible one. Despite being seriously injured, what is, and is not the relevant injury is parsed by the injury caused. Defendant A would be liable for the broken legs, while defendant B would be liable for the broken hands. To the unfortunate plaintiff, the difference is a meaningless one; but to the Defendant B, being liable for $\$ 100,000$ dollars for which he is not responsible ${ }^{494}$ is deeply important.

\footnotetext{
491 Ibid.

${ }^{492}$ For a fascinating discussion of divisble injury in a criminal law context, see $R v$ Maybin, [2012] 24 SCC .

493 Facts loosely drawn from Fitzgerald $v$ Lane, [1987] 1 QB 781.

${ }^{494}$ See Snell v Farrell, supra note 7 at 298.
} 


\section{$B$ Should the Apportionment Rules from But-For Causal Tests Simply Be Transported to Material Contribution to Risk?}

The apportionment rules enunciated in section VIII(A) are well enunciated, and fairly clear. Exceptions and vagaries are relatively rare, with apportionment an established and ordinary process. ${ }^{495}$ Both material contribution to risk and but-for causation seek to establish the responsibility of the defendant for the injuries the plaintiff complains of. All of the other steps involved in negligence are the same in each case. Why shouldn't the apportionment rules from but-for causation be ported over to material contribution to risk cases?

The answer is a relatively simple one: but-for looks to the responsibility for the harm the plaintiff suffered—-material contribution to risk does not. The two causal tests look for responsibility for fundamentally different objects. The plaintiff who has contracted mesothelioma and proves a causal link under material contribution to risk, is not suing for the mesothelioma. ${ }^{496}$ The plaintiff is suffering for the contribution to the risk of contracting the mesothelioma. ${ }^{497}$ Such a contribution will almost inevitably be only part of the risk that the plaintiff was exposed to. Under but-for causation, the plaintiff would not be suing for the risk — they are suing for the mesothelioma itself. If the defendant was found responsible under but-for, the law of causation finds that the defendant in fact caused the harm, and should be responsible for that harm. If the defendant was found responsible under material contribution to risk, the law does not find that the defendant caused the harm. The law finds only that the defendant caused the risk. As a result, it would be problematic to blithely apply the apportionment rules from but-for to material contribution to risk. There be dragons.

\footnotetext{
${ }^{495} \mathrm{Klar}$, supra note 11 at 531.

496 Fairchild v Glenhaven Funeral Homes, supra note 69.

${ }^{497}$ Jane Stapleton, supra note 6.
} 
Instead, a thorough consideration of what rule should would best reflect the fundamentally different nexus of the material contribution to risk inquiry. This nexus—risk-necessitates considerations not required in considering apportionment under a harm nexus.

\section{$C$ The Apportionment Options}

The apportionment rules available to be considered vary as endlessly as the scholarly mind can conceive of them. What is important is to consider the options that are useful. The assessment of these options in section VIII(E) is rigidly selects the apportionment test that best applies the nature of the material contribution to risk inquiry, and the goals of corrective justice. This sub-section lays out, and considers the most useful apportionment options, and begins to show the assets and liabilities of each. It is deliberately introductory in nature. Many readers can, and will, disagree with the corrective justice justified apportionment rule I craft at the end of this section. This introductory part of the chapter undertakes the relatively simple and non-controversial task of naming the options, and determining if any of these options on a cursory assessment, is the obvious apportionment rule for material contribution to risk.

\section{Joint and Several Liability}

Applying joint and several liability to material contribution to risk is the current approach to material contribution to risk applications in the UK. ${ }^{498}$ It is, of course, necessary to note that this position was reached through the UK Parliament overturning the decision in Barker, and that, in the UK, material contribution to risk seemingly applies only to

498 Compensation Act, supra note 292, s 2. 
mesothelioma cases - thus making the ambit of this outcome thoroughly more limited than it would be in Canada.

Any application of the rule of joint and several liability would necessarily involve an indivisible injury. Each of the major Supreme Court cases in Canada where material contribution to risk has been discussed has involved such an injury. ${ }^{499}$ Applying the rule of joint and several liability at the apportionment stage would involve making any culpable defendant liable in solidum for the plaintiff's loss. As an example, recall the facts of Athey. Assume, here, that the court applied material contribution to risk, instead of but-for causation. In Athey, under but-for causation, the plaintiff's injury (disc herniation) had four separate causes: an earlier injury, two car accidents, and non-negligent advice by his doctor to resume exercise. Bear in mind, that the harm being considered under material contribution to risk is not the disc herniation, but the contribution to risk of such an outcome. Here, the only potential tortfeasors would the drivers of the two separate cars. If both drivers were available as tortfeasors, a court would then consider the relative liability of each driver to each other, ${ }^{500}$ but fully compensate the injury. If one of the two drivers were found to be more causally responsible, he would pay a greater amount than the other defendant. Such an outcome makes intuitive sense.

In joint and several liability, however, each wrongdoer is liable for all of the harm, even if they are not the only factual cause. ${ }^{501}$ To continue referring to Athey, assume that one of the drivers was deceased, insolvent, or unknowable. If a joint and several liability rule of apportionment was applied, the other driver would still be liable for the entirety of the harm.

\footnotetext{
499 Snell v Farrell, supra note 7 (A single eye injury); Athey v Leonati, supra note 1 (A herniated spinal disc); Walker Estate v York Finch General Hospital, supra note 1 (Transmission of a disease passed through tainted blood);

Resurfice Corp v Hanke, supra note 1 (Serious single-source burns); Clements v Clements, supra note 1 (Traumatic injuries from a motorcycle accident).

500 G (ED) v Hammer, [2003] SCC 52.

$501\{$ Citation $\}$
} 
The logic for this outcome is that the defendant is, morally, the better party to bear the burden in such a situation. ${ }^{502}$ It would be inherently unfair for the burden to be borne by the plaintiff, with the plaintiff being correspondingly undercompensated—sometimes grossly. ${ }^{503}$ In Athey at least, the defendant or defendants would be liable for the entirety of the plaintiff's loss. It is a long-held principle that the defendant takes the plaintiff as they find them. The pre-existing back injury—as long as it was not found to be the 'cause' of the disc herniation—would not be discounted from the defendant's liability.

This discussion of how joint and several liability would appear in material contribution to risk is, thus far, a superficial one. There are several different ways in which joint and several liability can operate to alter its effect.

\section{(a) Joint and Several Liability: No Lower Bound}

Material contribution to risk cases are inherently complex ones. The trigger for material contribution to risk almost necessitates several tortfeasors and a heavy "rock of uncertainty". ${ }^{504}$ One possible conception of the joint and several rule of apportionment would not set a lower-threshold for defendant contribution to risk. The core of the rationale of joint and several liability is that defendants, not the plaintiff, should bear the liability when negligent contributors to the plaintiff's harm are unavailable to contribute to the harm. ${ }^{505}$ From the plaintiff's perspective, they face a pool of wrongdoers, and are entitled to be fully compensated for this wrongdoing. From the defendant's perspective, each is a relevant 'cause' of the plaintiff's injury, and cannot shirk responsibility to redress the plaintiff's injury because fellow causes are not available to contribute. From a moral standpoint, this logic

\footnotetext{
502 David Cheifetz, Apportionment of Fault in Tort (Toronto: Canada Law Book Ltd, 1981) at 19.

503 David Cheifetz, supra note 502.

504 Sienkiewicz, v Greif (UK) Ltd, supra note 3, para 186.

505 David Cheifetz, supra note 502.
} 
seems persuasive. The fact that the defendant may be 'unlucky' to the only one liable for the entirety of the plaintiff's injury reflects the nature of the causal process. If one hundred hunters negligently fired into a wood in which the plaintiff was standing, but ninety nine of those hunters missed, and only one struck, the law of negligence would have no issue in making that defendant fully liable; even if the only thing that separated him from the other ninety nine hunters was sheer bad luck. The 'bad luck' of being the last defendant available, in this conception of joint and several liability, would not preclude the defendant being fully liable.

\section{(b) Assets and Liabilities}

Joint and several liability has obvious benefits; but correlated to each of these benefits is an associated deleterious effect.

These benefits are, however, significant. Firstly, an unbounded joint and several liability apportionment scheme would be coherent with the underpinning logic of material contribution to risk being a principle to avoid injustice to plaintiffs. It would seem perverse to, on the grounds of fairness and justice, to permit a causal link, but then apportion damages in a manner that left the plaintiff uncompensated. Secondly, joint and several liability is clear. Plaintiffs need only isolate one defendant. Thirdly, this apportionment rule places the burden of seeking contributors to the harm on the defendant. Having already been isolated as wrongdoers, it makes intuitive sense to place such a burden on a culpable, not innocent party.

The liabilities of the unbounded joint and several liability are also significant, and likely outweigh the assets. Firstly, material contribution to risk operates on determining liability for risk not harm. Risk, unlike some harms, is divisible, and to treat risk as a collectivized responsibility ignores this reality. Secondly, the burden upon defendants is a 
potentially crushing one. A defendant who was responsible for a small amount of the risk, despite not acting jointly with any fellow defendant, could be liable for the entirety of the risk. Such a burden would be onerous. Thirdly, such a joint and several liability apportionment rule is a rigid one. The Court in Sienkiewicz was notably discontented that, ${ }^{506}$ despite having determined less than a decade ago that the appropriate apportionment rule was proportionate liability, after the Compensation Act, they were compelled to apply joint and several liability.

Balancing the assets and liabilities makes it apparent that such a rule of apportionment would be an unduly onerous one. It is not immediately obvious that such an apportionment rule would do more than shift the injustice from the plaintiff to the defendant. The decision making process seen in the UK Parliament to overturn the elaborately reasoned Barker and insert a joint and several liability rule seemed a deeply flawed one. The decision in Barker was characterized by members of Parliament in thoroughly emotive terms: being, by turn, phrased as "appalling" and "outrageous and wholly unacceptable" ${ }^{507}$ Such a rationale does not seem a compelling response the careful reasoning in Barker. The UK experience of the implementation of joint and several liability supports the view that such a rule is unduly onerous. The lack of flexibility in such a rule can, and does lead to perverse results, as the outcome in Sienkiewicz attests. ${ }^{508}$

An unaltered version of joint and several liability seems a problematic apportionment rule. The experience in the UK suggests that to apply such a rule in the Canada would compel results that only shift the manifest unfairness from the plaintiff to the defendant.

506 Sienkiewicz, v Greif (UK) Ltd, supra note 3, para 222.

507 Great Britain: Parliament: House of Lords: Select Committee on the Constitution, Fast-track Legislation: Constitutional Implications and Safeguards, 15th Report of Session 2008-09, Vol. 2: Evidence (London: The Stationery Office, 2009) at 170.

508 Turton, supra note 295; Stapleton, Jane, supra note 5. 


\section{(c) Joint and Several Liability-A Sui Generis Model Tailored For Material}

\section{Contribution To Risk}

This conception of the joint and several liability, while still one in which the plaintiff's right to full compensation is paramount, considers the perspective of the defendant somewhat more. While it is morally fair for wrongdoers, not plaintiffs, to bear the burden of fellow insolvent wrongdoers, such a view has limits. ${ }^{509}$ This form of joint and several liability operates in the same manner as the one above, but does place limits on the rule to correspond to the reality that material contribution to risk places different demands on apportionment when compared to but-for causation.

\section{(i) Setting a Des Minimus Threshold}

This conception of joint and several liability has limits of liability in relation to defendants who have a very small contribution to the risk. As an example, look to Smiths Docks Ltd v Patterson, ${ }^{510}$ which was heard at the same time as Barker to resolve the apportionment issue. Patterson had been negligently exposed to asbestos by four different employers: Smiths Docks, Vickers Armstrong, Swan Hunter \& Hawthorn Leslie. The latter two wrongdoers had exposed Patterson to 83 per cent of the risk, while former two had exposed him to only 17 per cent of the risk, roughly equally shared between the two Defendants.

The latter two wrongdoers were insolvent, as were their insurers, ${ }^{511}$ making two first two defendants the only potential tortfeasors. It bears reminding that while Barker declared liability in Patterson to be proportional; the Compensation Act passed three months later had

\footnotetext{
509 Barker v Corus, supra note 246.

510 Smiths Docks Ltd v Patterson, supra note 276.

511 As is exceedingly common in cases involving mesothelioma Stapleton, Jane, "Two Causal Fictions at the Heart of US Asbestos Doctrine” (2006) 122 Law Quarterly Review.
} 
retrospective effect, effectively rendering the liability there joint and several. ${ }^{512}$ Under a scheme of joint and several liability, the defendants in Patterson, despite contributing only a relatively small amount of the liability were liable, after the Compensation Act, for all of the damage suffered. If Vickers Armstrong were insolvent, then Smiths Docks, despite their 8.5 per cent risk contribution, would be responsible for 100 per cent of the liability. Surely there must be a lower bound placed upon joint and several liability.

Mesothelioma would, in Canada, be a causal trigger candidate for triggering material contribution to risk. ${ }^{513}$ It would not be the only causal trigger, but, as an example, serves as a useful illustration of the difficulties that material contribution to risk faces when determining an apportionment rule. As noted in Sienkiewicz: "there is no known lower threshold of the exposure that is capable of causing mesothelioma." ${ }^{514}$ Thus, there is no such thing as an immaterial contribution to risk of contracting mesothelioma. As Stapleton noted, in one case, a mesothelioma victim's only exposure to asbestos had been one afternoon playing on asbestos sheets as an infant; another victim had only been exposed on one occasion when removing an asbestos shed. ${ }^{515}$ Effectively, every negligent exposure to risk of mesothelioma is a material one. The existing common law norm of des minimus non curat lex does not apply usefully to risk $;{ }^{516}$ and certainly does not apply usefully to material contribution to risk. There is no des minimus causal exposure in material contribution to risk cases like mesothelioma. A court cannot discard even a small exposure, as that exposure may indeed be the full cause of their harm. There is, thus, no current common law principle that could enforce a lower limit to liability for material contribution to risk defendants in mesothelioma cases.

\footnotetext{
512 Constitution, supra note 507 at 181.

513 It has certainly become the exclusive trigger and causal candidate in the UK Barker v Corus, supra note 246.

514 Sienkiewicz v Greif (UK) Ltd, supra note 3, para 110.

515 Jane Stapleton, supra note 6 at 277-9.

516 Joseph Fiksel, "De Minimis Risk" in Chris Whipple, ed, De Minimis Risk, Contemporary Issues in Risk Analysis 2 (Springer US, 1987) 3 at 5.
} 
Any determination of a threshold to protect minimal risk contributors would, by nature, be an arbitrary one. This is arbitrariness is problematic, but not fundamentally vitiating. Stapleton rightly notes that any apportionment under material contribution to risk is, necessarily, artificial. ${ }^{517}$ The Court in Sienkiewicz had a similar notation. ${ }^{518}$ In such an information-poor environment, a guess, albeit an educated one, seems like the only option to circumnavigate the heavy "rock of uncertainty". 519

What this threshold is could be set in a number of ways. Firstly, this threshold could be set as a percentage amount-for example, defendants liable for less than ten per cent of the risk should not be made jointly and severally liable for the entirety of the risk. Secondly, this threshold could be set to mean that anything above des minimus would permit joint and several liability. The Court in $W$ alker and Athey certainly attempted to define 'material' in material contribution to risk thusly. ${ }^{520}$ Thirdly, and finally, some scheme of limiting the liability from one tortfeasor to another could be possible. Rather than setting an arbitrary threshold, instead, defendants could made liable for a potential multiplication of their contribution. For example, a defendant who contributed five per cent of the risk could be found jointly and severally liable for three times their risk contribution, capping their liability to that level.

\section{(ii) Excluding Non-Tortious Sources, Including Contributory Negligence}

This tailored joint and several liability rule would also, by necessity, exclude nontortious sources of the harm. Establishing contribution between parties is already an exceedingly vexed issue. Determining and quantifying a contribution to risk for uncertain

\footnotetext{
517 Jane Stapleton, supra note 6 at 300.

518 Sienkiewicz $v$ Greif (UK) Ltd, supra note 3, paras 130-137.

519 Fairchild v Glenhaven Funeral Homes, supra note 69, para 8.

520 Walker Estate v York Finch General Hospital, supra note 1, para 88; Athey v Leonati, supra note 1, para 15 Although such a conception seems to be a confused and confusing one.
} 
illnesses, when the contribution may have been decades old, makes for a vexing and exhaustive process. Corrective justice does make exceptions in but-for causation for collectivizing liability amongst several defendants. In but-for, once a causal link is proven, the apportionment acts upon the assumption that the defendants caused all of the harm, minus any contributory negligence by the plaintiff For the purposes of material contribution to risk, however, such assumptions cannot be made. Collectivizing liability among wrongdoers is coherent; even if not all wrongdoers are not available as tortfeasors. Collectivizing risk flowing from wrongdoers and risk flowing from innocent contributors does, not, however, appear coherent. ${ }^{521}$ If, for example, in Patterson, rather than all of the risk being attributable to the four wrongdoers, there was five per cent non-tortious contribution to the risk, Patterson would only be compensated for the ninety five per cent of the risk that was tortious. It should make no difference if that five per cent was a result of contributory negligence on the part of the plaintiff, background exposure, or exposure that within the responsibility of the defendant, but was not tortious. ${ }^{522}$

\section{(d) Assets and Liabilities}

The tailored joint and several apportionment rule seems a superior one to its unmodified joint and several iteration. Its considers that material contribution to risk is a significantly different causal process; but it may indeed be that even with tailoring, joint and several liability is still not a viable apportionment scheme.

There are three significant assets of this tailored joint and several liability scheme.

Firstly, miniscule contributors will not be found liable for the entirety of the risk exposure, banishing the spectre of indeterminate liability. Secondly, this apportionment rule is still

521 Jane Stapleton, supra note 6 at 290.

522 As was observed in Bonnington Castings v W ardlaw, supra note 241. 
relatively plaintiff centric. Unlike other rules, the plaintiff is, in most cases, likely able to achieve significant compensation. Thirdly, the tailored parts of this rule are formed in the context of the binary plaintiff-defendant relationship, with the limits on defendant liability a reflection of the responsibility they have to the defendant - and are thus not a reflection of some collectivised responsibility between unconnected defendants.

The liabilities, however, militate against ready acceptance of this apportionment rule. Firstly, the fact that the tailoring will inevitably be artificial does necessarily mean that setting arbitrary thresholds is a viable outcome. Setting a non-discretionary rule threshold or multiplier rule seems to create a bright line with little logical basis. Secondly, defendants are, under such a rule, still being made responsible for more than their divisible contribution to risk. The burden on defendants seems a cumbersome one. Carrying over a rule that applied to indivisible injuries under but-for to divisible risk under but-for, even with tailoring, seems to be a seriously problematic grafting of concepts. Thirdly, this apportionment rule can be criticised from the opposite perspectives. Rules of joint and several liability consider the degree of responsibility only when looking at the contribution from one negligent party to another. Even if one party under ordinary joint and several liability is responsible for a small causal percentage, they are still fully liable for the entirety of the plaintiff's loss at trial. The small causal percentage, there, is properly addressed in assessing contribution between defendants, not in determining responsibility to the plaintiff.

Balancing the assets and liabilities for tailored joint and several liability is a more delicate task than it was for un-tailored version. It does, however, appear that tailored joint and several liability is not an obvious or easy choice as the apportionment rule under material contribution to risk. This apportionment rule does avoid the extreme, outlier results that are possible under unmodified joint and several liability. Miniscule risk 
contributors are not crushed under the weight of their more culpable co-wrongdoers.

Avoiding such outcomes seems necessary to avoid injustice to defendants. There are, however, two persistent issues that do not appear to be reconcilable. Independently, both would likely be problematic for approving of this tailored joint and several liability: together, they almost certainly do. Firstly, the reality is that joint and several liability is a synthetic port over from an area where the actionable harm is harm, not the risk of harm. Risk is divisible, and discrete. Harm is not always so. Unless there is some rationale to collectivize the risk between defendants—for example, joint purpose or vicarious liability—aggregating responsibility has no coherent rationale. In the ordinary case, any joint and several rule, even with extensive tailoring, runs fundamentally against the nature of the material contribution to risk inquiry. The second vitiating problem concerns the arbitrariness of the tailoring. There is a coherent justification for limiting the bounds of the liability to tortious sources. Such coherence cannot be found in setting of a lower threshold. The des minimus, percentage level, or multiplier are all obviously arbitrary. In Thompson v Smiths Shiprepairers, Mustill J, while acknowledging imprecision in apportionment, stated: "what justice does demand, to my mind, is that the court can make the best estimate it can, in light of the evidence, making the fullest allowances in favour of the plaintiffs for the uncertainties known to be involved in any apportionment". ${ }^{523}$ Scientific precision is not necessary, ${ }^{524}$ but arbitrariness is seriously problematic. Under joint and several liability, dealing with minor contributors in cases where they are the only available tortfeasors appears to be an intractable problem. There may indeed be some way in which to determine a tailored rule to avoid crushing liability on minor contributors; but, a coherent and non-arbitrary method is thoroughly elusive, and, perhaps, impossible.

523 Thompson v Smiths Shiprepairers (North Shields) Ltd, supra note 488 at 364 (Mustill J).

524 Alphacell Ltd v Woodward, [1972] AC 824 at 490. 
The tailored joint and several liability rule cannot be put forth as an obvious candidate for the best apportionment rule under material contribution to risk. Despite avoiding the extremes of the unmodified joint and several rule; this tailored rule still cannot address the reality of the new causal enquiry: that risk, not harm, is the gist of the causal process. It seems that no enunciation of joint and several liability as an apportionment rule can be a useful one until this reality is overcome.

\section{Proportionate Liability}

To implement proportionate liability would be to follow the rather exhaustive reasoning in Barker. Each defendant will be liable only for their contribution to risk. If, for example, ten different defendants negligently exposed a plaintiff risk in equal portions, each defendant would be liable for ten per cent of the plaintiff's loss. If one or more defendants became insolvent, unreachable, or otherwise not accountable to remedy his wrongdoing, the liability of the fellow defendants is unchanged. Each defendant's liability would be only in response to his responsibility of redress to the plaintiff, as per corrective justice. ${ }^{525}$ Determining what would constitute a portion of this proportionate liability rule of apportionment would be one that would need to be applied on a case by case basis, but general statements can be made.

\section{(a) Including Innocent Contributions as a Relevant Proportion}

Firstly, the calculation of the risk of harm should be in relation to the global risk of harm. ${ }^{526}$ What is assessed as proportionate is determined by the background contribution of risk plus the tortious contribution to risk. In Patterson, all of the risk was tortious, thus, each defendant would be responsible for their portion of the asbestos particles to which they

525 See Ripstein \& Zipursky, supra note 160.

526 Barkerv Corus, supra note 246, para 128 (Baroness Hale). 
negligently exposed the plaintiff. If Smiths Docks exposed the plaintiff to 8.5 million particles, Vickers Armstrong 8.5 million, Swan Hunter 41.5 million, and Hawthorn Leslie 41.5 million, and there was no other innocent or non-tortious contribution to risk, then each plaintiff would thus be responsible for 8.5 per cent, 8.5 per cent, 41.5 per cent, and 41.5 per cent of the liability respectively. ${ }^{527}$ Imagine, instead, that in addition to the 100 million particles to which Patterson had been negligently exposed, he had also been exposed to another 100 million particles from non-tortious sources. As a result, Smiths Docks and Vickers Armstrong when combined have only contributed 9 per cent of risk: and are thus only liable to that extent. ${ }^{528}$ In Athey, if the material contribution to risk was applied, the preexisting back injury doubtlessly contributed to at least some proportion of the risk of disk herniation. ${ }^{529}$ As risk was the responsibility of the plaintiff, this would reduce the global responsibility of the negligent defendants by the corresponding proportionate amount.

\section{(b) Determining Risk by Likelihood, not Duration}

Secondly, the proportion of risk would have to be closely considered. For example, in terms of mesothelioma, the proportion of contribution to risk would be determined by intensity of exposure multiplied by time. For example, a defendant responsible for the plaintiffs exposure to 1000 asbestos particles a day, every day, for a week would be proportionately half as liable as a defendant who was responsible for the a 14,000 asbestos particle exposure over one day. In other cases, great care would have to be taken to ensure that the risk is limited appropriately. Long-running risks that have a relatively low contribution to risk would have to be considered in comparison to short, but risky activities.

\footnotetext{
527 Smiths Docks Ltd v Patterson, supra note 276 The ratios of responsibility, and the assumption that risk exposure was contained entirely to these parties was presumed in this case. The number of particles is uncountable, I only number them here to clarify the allegory. .

528 These hypothetical facts mirror the 18 per cent liability of Greif in Sienkiewiczv $v$ reif (UK) Ltd, supra note 3. 529 Athey $v$ Leonati, supra note 1, para 1.
} 
In a case of Vibrating White Finger Syndrome, for example, many years of sanding on a low vibration grinder would have to be considered in proportion to a short period of months on a high vibration jackhammer. ${ }^{530}$

\section{(c) Being Frank About Fictions}

Thirdly, under a proportionate rule of apportionment, it is necessary to frankly acknowledge the artificial nature of apportionment under material contribution to risk. ${ }^{531} \mathrm{In}$, for example, a mesothelioma case, it may well be that the first particle of asbestos actually caused the mesothelioma, and all later exposures to risk were causally irrelevant. Equally, in a medical negligence case, it may well be that only one of a litany of factors was the true cause; and all other competing causes were ultimately irrelevant. The proportionate rule of apportionment would frankly acknowledge that apportionment is, by necessity, "rough justice" ${ }^{532}$ both between defendants and between the defendant and the plaintiffs.

\section{(a) Assets and Liabilities}

Proportionate liability has the benefit of a close connection to corrective justice in that it explicitly links and quantifies the responsibility of each defendant only in terms of their obligation to the plaintiff. It does, however, face the reality of placing an onerous-and often impossible_-burden on a plaintiff to join as many potential defendants to a case in order to achieve something resembling full compensation for their loss.

There are four significant assets inherent in a rule of apportionment based on proportionate liability. Firstly, proportionate liability is thoroughly consistent with corrective justice. The responsibility of the defendant to the plaintiff is arithmetically calculated, and discharged through compensation. Such a position reflects closely, indeed, fundamentally,

530 See Brown \& Ors v Corus Ltd, [2004] 374 EWCA Civ (UK Court of Appeal).

531 Jane Stapleton, supra note 6 at 300.

532 Sienkiewicz, v Greif (UK) Ltd, supra note 3, para 187. 
the bipolar nature of corrective justice. Secondly, proportionate liability avoids aberrant results like that in Sienkiewicz, where the vast majority of the risk being not in the control of the defendant did not prevent the defendant being fully liable for the injuries to the plaintiffs. Thirdly, proportionate liability has no lower bound. A defendant who was responsible for a tiny portion of the risk will still be forced to recompense the plaintiff: there are no 'free-riders', to use a borrowed term from economic theory. ${ }^{533}$ Fourthly, proportionate liability is consistent. Over time, a body of rules to determine how to determine a percentage quantification of contribution to risk will be generated, making such calculations exponentially easier as a critical mass of decisions is made.

There are, however, four significant liabilities in a proportionate rule of apportionment. The first, and most compelling, is that proportionate liability will, in almost every case, leave the plaintiff undercompensated. Especially in material contribution to risk cases, where the facts are complex, defendants difficult to isolate, and risk exposure periods are lengthy, many, if not most, sources of risk will not be actionable. As a result, any damage awards a plaintiff receives will be correspondingly low. Secondly, apportioning damage in terms of risk is already a vexing enough process without attempting to financially calculate one quotient of risk in comparison to another quotient of risk. Such a task will necessarily be a blunt and somewhat arbitrary process. ${ }^{534}$ Thirdly, the necessary inclusion of non-tortious risk sources into proportionate liability means that even when no defendants are insolvent or otherwise unavailable, the plaintiff will still be undercompensated due to the existence of a background exposure to risk. Fourthly, it seems disjunctive to apply material contribution to risk, a plaintiff-centric rule based upon policy; but then to apply an apportionment rule that

\footnotetext{
533 Sanford J Grossman \& Oliver D Hart, "Takeover Bids, The Free-Rider Problem, and the Theory of the Corporation" (1980) 11:1 The Bell Journal of Economics 42.

534 Jane Stapleton, supra note 6 at 290; Thompson v Smiths Shiprepairers (North Shields) Ltd, supra note 488.
} 
inherently favours defendants. Such a proposition surely appears contrary to continued expression by the Supreme Court that the purpose of material contribution to risk was to remedy injustice. ${ }^{535}$

There appears little way to meaningfully balance the powerful assets, and equally powerful liabilities of proportionate liability. Material contribution to risk is a "rule based on policy", ${ }^{536}$ with this underlying policy being the resolution of injustice to plaintiffs under butfor causation. The Supreme Court has persistently been clear that, where they see such injustice, they will modify rules in negligence to overcome this injustice. This does, however, need to be balanced with the emphasis, especially in Clements, ${ }^{537}$ that corrective justice is the underlying rationale for tort law. ${ }^{538}$ After consideration in section IV of this thesis, I can't help but agree. Inherent in this conception of corrective justice is view that the relationship that matters to the law of negligence is the relationship between the plaintiff and the defendant. To once again refer to the Court in Snell, which was cited with approval in Clements: "Causation is an expression of the relationship that must be found to exist between the tortious act of the wrongdoer and the injury to the victim in order to justify compensation of the latter out of the pocket of the former". ${ }^{539}$ Appended to the material contribution to risk rule of causation, a proportionate rule of liability reifies, and monetizes this relationship. In but-for causation, corrective justice is satisfied in aggregating this binary relationship in rules of joint and several liability because, in these cases, the injury to the victim is the harm they complain of. In these cases, the actions of the defendants in causing an indivisible injury occlude the process of determining how the injury came about. As a result, compensation

\footnotetext{
${ }^{535}$ For example, Walker Estate v York Finch General Hospital, supra note 1, para 88.

536 Sam v Wilson, [2007] BCCA 622, para 109 Citing ; Fairchild v Glenhaven Funeral Homes, supra note 69, para 33.

537 Clements v Clements, supra note 1, para 7.

538 Weinrib, supra note 67.

539 Snell v Farrell, supra note 7 (Emphasis mine).
} 
for the whole of the injury is within corrective justice. In material contribution to risk, however, the risk is the harm: despite difficulties in calculating this risk, such a task is not impossible. The risk is the harm; and it is possible to assess this harm in cognizable, quantitative manner. Risk is divisible; it makes sense for the liability to correspond to this divided contribution. These two countervailing arguments seem to be at equipoise. On the one hand, material contribution to risk is a rule created to resolve the injustice the plaintiff: proportionate liability almost ensures that plaintiffs will be undercompensated, and thus not receive full justice for their injuries. On the other hand, the law of causation, the forebear of material contribution to risk, as well as the entire law of negligence, is premised upon corrective justice. Corrective justice mandates that the relationship between the plaintiff and defendant be the sole determinant of the liability of the latter to pay the former, unless particular exceptions can be found. These exceptions do not appear to be in existence.

As it stands, it seems impossible to put forth proportionate liability as an ideal apportionment candidate. It presents significant virtues; but also significant harms. It seems, in its ordinary form, to be a source of more conflict than certainty.

\section{A Discretionary Rule of Apportionment}

It is not strictly necessary to have the rule of apportionment set to universal in application. Judicial discretion, despite being much maligned in some areas, ${ }^{540}$ remains a highly useful area to prevent rigidity necessitating injustice. The Court in Snell made such a notation in relation to causal tests: "the dissatisfaction with the traditional approach to causation stems to a large extent from its too rigid application by the courts in many cases". ${ }^{441}$ A discretionary rule of apportionment could take its inspiration from legislation.

\footnotetext{
${ }^{540}$ Frank H Easterbrook, “Judicial Discretion in Statutory Interpretation” (2004) 57 Okla L Rev 1.

541 Snell v Farrell, supra note 7 at 328.
} 
For example, the Alberta Tortfeasors $A c t,{ }^{542}$ has a potential scaffold for such an apportionment rule:

(2) In any proceedings for contribution under this section, the amount of the contribution recoverable from any person shall be an amount that the court finds to be just and equitable having regard to the extent of that person's responsibility for the damage.

(3) The court has power

(a) to exempt any person from liability to make contribution, or

(b) to direct that the contribution to be recovered from any person shall amount to a complete indemnity. ${ }^{543}$

Thus, the apportionment rule becomes a relatively simple one. In cases where to make the defendant liable for part, or all of the damages award would be un-just or un-fair, the defendant could be freed of his obligation to contribute. In cases where to leave a defendant — who, bear in mind, has to have proven to causally connected to the harm—as paying an amount that was un-just or un-fair, this amount could be reapportioned to equate to a larger share of the plaintiff's loss. The only problematic moment in the apportionment process becomes in defining what constitutes 'just and equitable' ${ }^{544}$

\section{(a) Assets and Liabilities}

This discretionary rule of apportionment has obvious assets; and equally obvious liabilities.

The assets are the clear starting point. Firstly, such a rule of apportionment is morally fair: it assesses culpability of the defendant qualitatively, not quantitatively. ${ }^{545}$ The disjunctive correlation between luck and outcome would be displaced. Secondly, the term 'just and

542 Alberta Tortfeasors Act, supra note 15.

543 Ibid, s 3(2).

544 Ibid.

545 Heller v Martens, supra note 271. 
equitable' is not unidirectional: it operates in the binary of corrective justice, ${ }^{546}$ with this assessment capable of both lifting and lowering the liability of the defendant in relation to his relationship with the plaintiff. Thirdly, discretionary apportionment is malleable. In Sienkiewicz, the UK Supreme Court was trammeled into an unjust and inequitable result ${ }^{547}$ based upon an immovable rule of apportionment-under discretionary apportionment, such an outcome would not be necessary.

The liabilities are, however, onerous. Firstly, 'just and equitable' is a perniciously hazy term. Nothing in its statement in the Alberta Tortfeasors Act suggests that 'just and equitable' is limited to the relationship between the plaintiff and defendant-making any such calculation vexingly contrary to corrective justice. Secondly, the calculation of 'just and equitable' as a discretionary process is laborious to implement. Any calculation of this nebulous conjunctive phrase would require expensive and cumbersome argument and judicial deliberation; and would create variable and unclear results. Thirdly, such a discretionary rule is unclear for potential defendants. Despite the judicial engagement with negligence being entirely premised on corrective justice, as noted in section IV, judgments have systemic effects. When a rule is clear, potential defendants can and will be deterred from incurring the weight of that rule, and, in theory at least, will be deterred from future negligence. Under an entirely discretionary rule of apportionment, deterrence is vitiated by this inherent uncertainty.

Balancing the assets and liabilities here is a somewhat tricky exercise. A discretionary apportionment rule does avoid the extreme cases in which obvious injustices are necessitated by arbitrary but inflexible rules. The Supreme Court has persistently stated that they would not balk in applying rules to avoid unjust outcomes. ${ }^{548}$ Certainty, however, does have its own

\footnotetext{
546 Weinrib, supra note 81.

547 Turton, supra note 295.

548 See, for eg Snell v Farrell, supra note 7; Athey v Leonati, supra note 1; Resurfice Corp v Hanke, supra note 1.
} 
virtue: and an entirely discretionary rule of apportionment is anathema to such certainty. The ability to avoid injustice in extreme cases is obviously an asset, but recalculating the law of apportionment to involve such an outcome in every case would be overdoing it somewhat. Discretionary apportionment, in the extra-ordinary case, seems a virtuous outcome; but to use this as the default rule in all material contribution to risk seems uniquely ill-suited to the often egregiously expensive and complex cases faced by material contribution to risk. It does not seem that a discretionary apportionment rule similar to that seen in the Alberta Tortfeasors Act would be a useful one.

\section{A Risk Pricing Model}

The risk pricing model is one of explicitly stated instrumentalist goals. ${ }^{549}$ Rather than a graft on to causation, it is an entirely new system of conceptualizing negligence. Sarah Green, in giving shape to this concept, terms it an approach to causation and apportionment of damages, ${ }^{550}$ but it seems that the theory is substantially than this. I have included this model in the list of possible alternatives, because even after corrective justice has been shown to be the animus for negligence, and the causal process, instrumentalism seems a promising division of negligence theory. The UK Parliament certainly saw it to be so when, in passing the Compensation Act, they "firmly reject(ed) any corrective justice basis for liability and to pursue the utilitarian goal of compensation of victims of mesothelioma" ${ }^{551}$ The appeal of the risk pricing model is that is a model of gradients - it rejects the all-or-nothing apportionment seen in but-for causation. ${ }^{552}$ Overcoming this seemingly arbitrary threshold has inherent attractiveness.

\footnotetext{
549 S. Green, supra note 13.

550 Ibid.

551 Turton, supra note 295 at 170.

552 See especially Peter Cane, The Anatomy of Tort Law (London: Hart Publishing, 1997) at 171-5.
} 
The risk pricing model seeks to define the "legal causative inquiry for what it really is - a recognition of responsibility for tortious contribution to damage in the face of universal uncertainty". ${ }^{553}$ The risk pricing model does not attempt to apportion harm based upon the defendant having 'caused' the harm of the plaintiff; nor does it attempt to apportion harm in explicit terms of the increase in risk. Instead, it attempts to apportion damages based upon the increase of risk by the defendant above an accepted objective standard. For example, in Sienkiewicz, ${ }^{554}$ the vast majority of the majority of the asbestos to which the plaintiffs were exposed was background asbestos particles inhaled in daily life; and thus attributable to no party. The risk pricing principle is premised on its "two main contentions:

1. The answers to all causal questions can be calibrated in terms of risk.

2. Defendants should only be liable to the extent that to which they increase the claimant's exposure above an acceptable standard" $\$ 555$

In the risk pricing model, all individuals are simultaneously potential suppliers and causes of risk — at this point, all individuals are at a point of equilibrium. ${ }^{556}$ This equilibrium "is the state of risk in which the cost to members of a society of being exposed to that level of risk is equal to the benefit they derive from contributing to that level of risk through their own activities" ${ }^{557}$ In the law of negligence under this model, breach is defined as any departure from this point of equilibrium. To undertake apportionment, all that need be done is to quantify the costs of the departure from this equilibrium: "ie, not the full costs brought about by the aggregate of all the risks to which the claimant had been exposed, but the costs

553 S. Green, supra note 13 at 164.

554 Sienkiewicz, $v$ Greif (UK) Ltd, supra note 3.

555 S. Green, supra note 13 at 166.

556 Ibid at 167.

557 Ibid. 
incurred by the proportion of that risk that had been inflicted upon the claimant both wrongfully and 'by that particular defendant"' ${ }^{558}$ Effectively, apportionment under such a scheme is a relatively simple task of:

- measuring the equilibrium,

- determining how much the culpable defendant departed from this,

- $\quad$ and then pricing this departure.

This explanation of the risk pricing model, albeit in summative form, relatively neatly encapsulates the concepts Green makes essential to its honest portrayal.

\section{(a) Assets and Liabilities of the Risk Pricing Model}

The risk pricing model has a series of substantial assets. Firstly, it is not bound by the binary all-or-nothing result in material contribution to risk. Secondly, it does a laudable job in sorting in, and out, background causes of risk. The risk pricing model would certainly have reached a different income to that seen in Sienkiewicz. Thirdly, the risk pricing model is a relatively simple, and is unfettered by the fictions so persistently prevalent elsewhere.

Fourthly, and finally, this model has a non-arbitrary correlation between risk, and actual risk. If a thoroughly freakish outcome occurred—for example, a pushed passenger, dropping a package, which ignited a firework, which displaced a scale, which fell on and injured the plaintiff $f^{59}$ — then the risk pricing model would price the risk of the negligently pusher to a level that is more appropriate and malleable than all or none of the crushed plaintiffs injuries.

These assets, however, are matched—as I see, it, overmatched—by the liabilities of such a model. Firstly, Green's model fundamentally ignores the purpose of each step in a

\footnotetext{
558 Ibid.

559 Facts drawn from Palsgraf v Long Island Railway Co, 248 NY 339.
} 
tort of negligence. Corrective justice is the animus for tort law; her model pulls entirely the other way. Secondly, the risk pricing model is altogether unclear. The all-important equilibrium seems impossible to calculate. Thirdly, in every case, the plaintiff will be compensated for less than the full costs of their injury. This is not inherently problematic, but the risk pricing model takes under-compensation to a new level. Fourthly, and finally, the risk pricing model attempts to systematically price the unpriceable. Determining a dollar value of deterrence, as well as likelihood of deterrence requires an army of behavioral psychologists, economists, sociologists, not to mention lawyers.

The balance of assets and liabilities, to my eye, does not seem to be finely balanced one. The risk pricing model does do away with some of the more persistent fictions in causation. The all-or-nothing binary that Green cites as the motive for the risk pricing is indeed the production of much injustice. Rather than simply responding to causal and apportionment difficulties, the risk pricing model seems to attempt to reinvent the wheel, and in doing so, breaks it. To fix the latent issues in causation, replacing the generally effective and malleable processes with nebulous new ones seems an inherent error. The lingering difficulties in defining what 'equilibrium', let alone establishing exactly how—or even if-damage awards deter defendants, leaves the foundations of the risk pricing principle set on perennially shifting sand. To take the view further, Green's model seems particularly foreign to the Canadian jurisprudence. ${ }^{560}$ Although there may indeed be some process of factoring in instrumentalist goals in the UK, such an approach is not the law of Canada. Canadian jurisprudence and corrective justice have a symbiotic relationship. The risk pricing model thus seems uniquely ill-placed as a rule of apportionment in the law of material contribution to risk.

560 Given the statement that tort in Canadian jurisprudence is based on corrective justice, such a model would be anathema Clements v Clements, supra note 1, para 7. 


\section{Summarizing the Apportionment Options}

The preceding section surveyed five potential apportionment rules. Of those, three were conventional rules: joint and several apportionment, proportionate liability, and discretionary apportionment. The other two rules, tailored joint and several liability and the risk pricing model, are novel options. The latter two rules were selected to reflect the relative novelty of material contribution to risk; and the awareness that analogy between extant apportionment rules under but-for may not be so readily carried over to material contribution to risk. In outlining these five different tests, I also briefly noted the obvious assets and liabilities of each scheme. As a corollary, I assessed whether any of the five apportionment rules seemed inherently preferential. None were obvious or instant candidates to be clearly a desirable apportionment test.

The first apportionment rule, joint and several liability made it only necessary the plaintiff to find one of the contributors to risk in order to receive full compensation for their injury. This contributors could seek contribution in a separate action from these other contributors, if they were available.

The second apportionment rule, tailored joint and several liability is a purely hypothetical form of joint and several liability. It served as an attempt to recast joint and several liability to lessen the potentially onerous liability on defendants that came from the application of joint and several liability to material contribution to risk. In recasting the rule, some scheme of setting a point below which liability would no longer be joint and several was necessary. Equally, excluding non-tortious sources was also part of the modification of joint and several liability to make it more applicable to material contribution to risk causal analysis. 
The third apportionment rule, proportionate liability is a standard, and relatively simple, apportionment rule. It finds defendants liable for their contribution to the plaintiffs injury. In material contribution to risk, this contribution would manifest in a percentage representation of the risk. If a defendant contributed, for example, eighteen per cent of the risk, they would be liable only for this 18 per cent of the plaintiff's losses; even if all of the fellow sources of the risk were not available to compensate the plaintiff. ${ }^{561}$

The fourth apportionment rule, discretionary liability, is an admittedly uncommon apportionment rule, despite my modeling its phrasing upon provincial legislation. Such a rule would determine, on a case by case basis, what was just and equitable to the parties before the court.

The fifth apportionment rule, the risk pricing principle, is, at this juncture a purely hypothetical one. It represents an attempt to crystallize instrumentalist concerns of the role of luck and arbitrariness in apportionment in the current schemes of apportionment. The risk pricing principle was not created explicitly with material contribution to risk in mind, but I selected it for analysis because it does effectively consider and deal with the issues of arbitrariness and absolutism seen in the other apportionment tests.

Of each of these five tests, there was no clear or obvious candidate as the apportionment rule to apply under material contribution to risk. Each apportionment rule, despite having significant assets, had either matched or overwhelming liabilities. No apportionment currently conceived perfectly addresses the nature of the material contribution to risk causal enquiry. This does not, however, mean that no apportionment rule can be chosen. Instead, the best of the available options must be selected, even if it is necessarily imperfect. The following selection will make, and justify this selection.

\footnotetext{
${ }^{561}$ Example drawn from Sienkiewiczv Greif (UK) Ltd, supra note 3.
} 


\section{E Selecting the De Facto Apportionment Rule}

Selecting an apportionment rule necessitates the enunciation of criteria against which qualities that are desirable, or not, can be determined. These criteria need not be nebulous value judgments of desirability. Ultimately, in selecting a rule of apportionment, a choice must be made: but by having guidance on how to consider these choices, such a selection is made significantly easier.

\section{Finding the Selection Criteria}

Chapter IV of thesis, at length, adjudged that corrective justice best enunciates the goals of negligence law. Such an enunciation is imperfect, and no theory will do more than closely approximate the realities of legal practice. ${ }^{562}$ Corrective justice does provide significant goals against which any potential apportionment choice can be judged. The three most significant features of corrective justice for the purpose of apportionment are:

- maintaining the bipolarity of the relationship between plaintiff and defendant

- plaintiff compensation

- defendant deterrence $e^{563}$

These three goals are fundamental to corrective justice, and, ultimately, all of the law of negligence. In selecting the rule of apportionment, prioritizing these goals is necessary to keep the apportionment rule consistent with corrective justice. In selecting a rule of apportionment, practical matters are also necessarily a consideration. Coherence, clarity and consistency are three goals, that, while subordinate to corrective justice, are important to include in any apportionment selection. These goals each form one part of what I term

562 Peter Cane, supra note 552 at 171-176.

563 Weinrib, supra note 81; Coleman, supra note 78. 
'pragmatic goals'. These goals are subordinate to the corrective justice. They have been added to reify, where necessary, to otherwise somewhat abstract process of analysis.

\section{Evaluating The Apportionment Options Against the Selection Criteria}

The application of corrective justice derived selection criteria immediately makes several of the apportionment options obviously problematic. In selecting a rule of apportionment, in this section I will separate, one by one, the apportionment rules that do not appear strong against these selection criteria. I will do so in an ascending order, from weakest apportionment option to strongest apportionment option.

\section{(a) Risk Pricing Principle}

The risk pricing principle is not compliant with the corrective justice principles, nor is it compliant with the pragmatic goals. This is unsurprising: the risk pricing model was created to embody instrumentalist conceptions of the goals of negligence. ${ }^{564}$ These goals do not cohere with the goals of corrective justice. The risk pricing model does not adhere to a bipolar relationship between plaintiff and defendant. Indeed, this model is based upon creating an efficient allocation of risk amongst all defendants, but those present and negligent; and those who have not yet acted negligently. By pricing risk, the risk pricing model looks squarely towards shaping the behavior of the latter category of defendant. The present defendant is the obvious subject of the trial, but the apportionment rule is far more concerned with hypothetical, yet to be negligent, possible defendant. Such other-regarding conceptions are fundamentally incoherent with corrective justice.

In terms of plaintiff compensation, the risk pricing model is also fundamentally incoherent. The risk pricing model is not fundamentally concerned with compensation of

\footnotetext{
564 S. Green, supra note 13.
} 
the plaintiff, despite the plaintiff initiating the action itself in order to obtain compensation. Instead, the risk pricing model is concerned with pricing risk in order to establish a norm of compliance among not present future defendants.

The risk pricing model seems to score highly in terms of defendant deterrence. As a model in which wrongdoer deterrence is the conceptual nexus, the risk pricing model appears to be strongly compliant. The reality, however, hinges on how 'defendant' is defined. Corrective justice, with its binary core, regards deterrence to be a narrower conception: the defendant that is the subject of corrective justice deterrence is generally the defendant at trial. The risk pricing model, despite making the defendant liable for his increase in risk above background levels, is concerned with deterring all defendants, especially hypothetical future defendants. Such a position clearly does not adhere to corrective justice.

In terms of the pragmatic goals, the risk pricing model appears similarly weak. Being a conceptual model only, there is no existing precedent surrounding the risk pricing model. Any selection of a risk pricing model would lead to the necessity of a substantial body of cases to be heard before even the most elementary parts of this model could be defined. ${ }^{565}$ Material contribution to risk is an already uncertain principle: grafting an uncertain apportionment rule to it would even further reduce certainty and clarity of outcomes.

The risk pricing model is not one that scores strongly against the selection criteria. It does not seem capable of being able to adhere to existing goals and purposes of negligence.

\section{(b) Discretionary Rule of Apportionment}

The discretionary rule of apportionment simultaneously can, and cannot be capable of adherence to corrective justice. A discretionary rule of apportionment is ultimately not capable of assessment in terms of corrective justice. The discretionary rule of apportionment

565 What constitutes the background level of risk is foremost amongst the unclear standards ibid at 163. 
is, by its nature, discretionary. It can be compliant with binary party consideration, plaintiff compensation and defendant deterrence. It can also be fundamentally incoherent with these dimensions. The phrasing of 'just and equitable ${ }^{566}$ is too open textured of a turn of phrase to be cognizable in terms of material contribution to risk.

In terms of the pragmatic goals, however, the discretionary rule of apportionment is capable of assessment. Clarity, coherence and consistency are rendered problematic under an apportionment system based upon discretion. Judicial interpretation is, especially before guiding stare decisis is laid down, highly variable. As the default rule, discretionary apportionment could lead to a wide array of outcomes. ${ }^{567}$ Any statement of what constitutes just and equitable ${ }^{568}$ would be bedeviled by the same criticisms that 'common-sense but-for causation $^{569}$ was also legitimately victim to. The breadth of any such statement makes consistency and clarity exceedingly difficult. Material contribution to risk already a principle that is difficult to apply consistently and clearly; having an even more variable rule of discretionary apportionment as the default apportionment rule would render reliable application even more problematic.

The discretionary rule is a poor candidate as the apportionment rule for material contribution to risk cases. It is difficult to assess in terms of corrective justice rules; and, in terms of pragmatic goals, scores exceedingly poorly.

\section{(c) Joint and Several Liability}

In outlining two different models of joint and several liability above, I deliberately kept them separate in order to allow for each to be carefully enunciated. In laying out their

\footnotetext{
566 Alberta Tortfeasors Act, supra note 15.

${ }^{567}$ Easterbrook, supra note 540.

568 Alberta Tortfeasors Act, supra note 15.

${ }^{569}$ Brown noted that "common-sense" and "pragmatic" were words devoid of particular, or useful meaning Brown, supra note 356.
} 
contents, this parsing was necessary for clarity. In assessing these two iterations of joint and several liability in terms of corrective justice, each can, however, be adjudged together. For the purposes of corrective justice, both the orthodox and tailored versions of joint and several liability score similarly when adjudged against the selection criteria.

Each scores relatively poorly on most of the criteria; but does excel in defendant deterrence, perhaps too much so. In creating joint and several liability as the apportionment rule in the UK, the Parliament explicitly eschewing corrective justice goals in lieu of instrumentalist goals. ${ }^{570}$ Such a position, given the continued emphasis in Canada on corrective justice, ${ }^{571}$ makes such a view seem very distant.

Joint and several liability appears to be deeply contrary to the strong emphasis placed on the bipolar plaintiff-defendant relationship in corrective justice. There are indeed several circumstances under but-for when joint and several liability applies, ${ }^{572}$ and is still compliant with this bipolar relationship. These circumstances are normally limited to joint purposes, vicarious liability, and the like, in which there is some common animus linking the defendants, making them responsible to each other as well as the plaintiff. ${ }^{573}$ In the but-for causation cases where joint and several liability, there is always something inherent in the facts of the case that necessitates collectivization of the defendants. ${ }^{574}$ To do where the gist of the action is a harm attributable to the defendants, such an outcome is compliant with corrective justice. In material contribution to risk cases, however, the gist is not harm, but risk. Defendants have not pursued a joint purpose, nor is the gist of the action one that is attributable to each of the defendants. The gist under material contribution to risk is the risk

\footnotetext{
570 Turton, supra note 295 at 170; UK Department Of Constitutional Affairs, supra note 296, para 13.

571 See especially Clements v Clements, supra note 1; Snell v Farrell, supra note 7.

572 See Glanville Williams, supra note 489.

573 Ibid.

574 Cheifetz, supra note 16 at 2.6.
} 
itself. To apply the rule of joint and several liability to defendants under material contribution to risk would be making the defendants responsible for the responsibilities of their fellow defendants, without any corrective justice compliant reason to do so. Collectivizing the liability of defendants under joint and several liability moves the responsibility of parties from bipolar to tripolar: the responsibility thus becomes plaintiffdefendant-fellow defendants. Such an outcome seems inherently incompatible with the core corrective justice emphasis on bipolarity being the crux of corrective justice.

In terms of plaintiff compensation, joint and several liability, even under the tailored model, scores highly. Under joint and several liability, the plaintiff will receive full compensation for their injuries, even if not all of the wrongdoers are available for contribution at trial. Under the classic joint and several liability model, all that is needed is for the contributor to one of the sources of the risk to be available as a tortfeasor for the plaintiff to obtain full recover. Under the tailored joint and several liability rule, the tortfeasor's contribution to risk would have to be above some threshold to make that tortfeasor subject to the joint and several liability rule. Both apportionment schemes are strongly compliant with the plaintiff compensation dimension of corrective justice.

Defendant deterrence is the most obvious issue with joint and several liability. Deterrence is achieved, but under either scheme, the deterrence does not correlate to the responsibility of the defendant—-sometimes fundamentally so. There is no requirement in the law of negligence for there to be a correlation between magnitude of wrongdoing and magnitude of harm. A intentionally negligent jostle on a healthy person may cause no substantial harm; yet an accidental negligent jostle on a person with an eggshell skull could yield substantial harm and corresponding liability. ${ }^{575}$ Corrective justice has no fundamental

575 Smith v Leech Brain \& Co, [1961] 3 All ER 1159. 
problem with such an outcome. The responsibility owed by the defendant is viewed in terms of their relationship to the plaintiff, not global conceptions of what is likely or not. To make a defendant liable for the risk contributed by his co-wrongdoers without a sufficient reason to collectivize this risk over-deters. In cases like Sienkiewicz, it radically over-deters to the level that seem to bear little resemblance to corrective justice.

The pragmatic goals achieve mixed success in joint and several liability. Certainly, clarity and consistency are obvious, especially under the unmodified joint and several rule of liability. In each case, the plaintiff need only join one defendant to achieve full compensation. That defendant is then compelled to seek out contribution from his fellow wrongdoers. Under the tailored joint and several liability rule, clarity is less obvious, but once the definition of the lower limit for joint and several liability to apply, consistency can be achieved. The problematic area is coherence. Both schemes of joint and several liability are incapable of providing a coherent justification for why defendants are being made liable risk that would otherwise be the responsibility of other parties. Under the tailored model of joint and several liability, the setting of the lower limit would inherently have to be arbitrary and incoherent. The deviation from the norms of corrective justice is, obviously, necessary. No theory is a perfect fit for the law it purports to cover. But without a coherent justificationwhich seems impossible here-for deviating from corrective justice; the collectivization of liability under joint and several liability militates against such a rule being a viable apportionment rule for material contribution to risk.

With systemic weaknesses in terms of bipolarity, deterrence and coherence, joint and several liability, even when tailored, is an inadequate rule of apportionment. It seems that applying either conception of this apportionment rule would simply relocate the injustice from uncompensated but innocent plaintiffs onto only partly responsible defendants. 


\section{(d) Proportionate Liability}

Proportionate liability accords most closely to corrective justice goals; and is relatively compliant with the pragmatic goals of consistency, clarity, and coherence. Significant shortcomings do exist, but, in this assessment, it seems inescapable that proportionate liability should form at least the core of the apportionment rule for material contribution to risk.

A proportionate liability rule of apportionment most clearly accords to the goals of corrective justice. It is, however, a far from perfect fit. Proportionate liability maintains a rigid bipolar consideration. The defendant's liability is limited to his responsibility to the plaintiff, expressed in quantitative terms. Contribution to risk is not like contribution to harm: it can, with some roughness, be calculated in those quantitative terms. In the UK case of Thompson v Smiths Shiprepairers Ltd, Mustill J noted both the difficulty and necessity of making such apportionment calculations:

\footnotetext{
Thus, whatever the position might be if the court were to find itself unable to make any findings at all on the issue of causation and was accordingly being faced with a choice between awarding for the defendants in full, or for the plaintiffs in full, or on some wholly arbitrary basis such as an award of 50 per cent., I see no reason why the present impossibility of making a precise apportionment of impairment and disability in terms of time, should in justice lead to the result that the defendants are adjudged liable to pay in full, when it is known that only part of the damage was their fault. What justice does demand, to my mind, is that the court should make the best estimate which it can, in the light of the evidence, making the fullest allowances in favor of the plaintiffs for the uncertainties known to be involved in any apportionment. ${ }^{576}$
}

The calculation under proportionate liability is one that reifies the relationship between the defendant and plaintiff. Certainly, allowances are and can be made when

576 Thompson v Smiths Shiprepairers (North Shields) Ltd, supra note 488 at 443-444. 
uncertainties are involved; but, at its core, the proportionate liability rule of apportionment reflects the bipolar relationship between the two parties. Proportionate liability, unlike joint and several liability, is concerned only with the two parties. The responsibility of other wrongdoers - be they solvent or not—is not within the consideration of a proportionate liability rule.

The most significant shortcoming with the connection between corrective justice and proportionate liability is that of plaintiff compensation. Corrective justice prioritizes defendant deterrence and plaintiff compensation equally, ${ }^{577}$ but, nonetheless, the weakness of proportionate liability to achieve compensation is a potentially vitiating shortcoming. Under a proportionate liability rule, plaintiffs will frequently be significantly undercompensated. Material contribution to risk cases in Canada will almost inevitably involve long time periods, substantial costs, complex facts, and a high chance of wrongdoers being insolvent or otherwise unavailable. The corollary of this is that plaintiffs in many cases will receive less than their entire share of damages. In some cases, such as Sienkiewicz, or Paterson, the plaintiff would have received roughly eighteen per cent of the damages they sought. When compared to the all-or-nothing standard rule under but-for causation, this is a radical undercompensation. The Court in Sam v Wilson noted that Material contribution is a plaintiffcentric rule of policy: ${ }^{578}$ it seems contradictory to establish a causal test designed to assist plaintiffs, then append an apportionment rule that will have a high chance of significantly undercompensating plaintiffs. In terms of plaintiff compensation, proportionate liability is successful in achieving some compensation: but, it seems inevitable that many, if not most, plaintiffs will be uncompensated. As a result, the plaintiff compensation dimension of corrective justice is not well recognized under the proportionate liability apportionment rule.

577 T.(G.) v Griffiths, supra note 153, para 24.

578 Sam $v$ Wilson, supra note 536, para 88. 
Defendant deterrence, however, is appropriately achieved under proportionate liability. While joint and several liability significantly over deters; proportionate liability correlates responsibility in wrongdoing to responsibility in compensation. A quantitative assessment of the plaintiff's exposure to risk yields each individual defendant's wrongdoing in terms of their risk contribution. If four defendants each independently exposed a plaintiff to risk, each in equal measure, every defendant would be liable for a 25 per cent share of the loss occasioned by the plaintiff. If that plaintiff's loss was $\$ 100,000$, each defendant would be liable for $\$ 25,000$ each, irrespective of the solvency of the fellow defendants. The contribution to risk of each defendant was a quarter of the plaintiff's loss; their liability is each a quarter of their loss. The connection between wrongdoing and liability is near-perfect; despite the substantial uncertainties about the contribution to harm that the plaintiff suffered. The proportionate liability model, unlike other apportionment rules, responds to material contribution being concerned with risk: as a result proportionate liability deters risk; and does so in a correlated fashion. In terms of deterrence, proportionate liability scores nearperfectly. Unlike joint and several liability, deterrence is proportionate to the risk contribution: thus, defendants area not over deterred—although, this results in most cases in plaintiff under compensation.

The pragmatic goals of coherence, clarity, and consistency are also relatively well-met by proportionate liability. The quantitative assessment of the contribution to risk is necessarily one that will be somewhat imprecise; but it can, to an extent, be approximated. ${ }^{579}$ Assessing liability to equal a percentage contribution to risk of the plaintiff's loss; and then compensating the plaintiff for this contribution is a fairly coherent method of compensation. The proportionate liability rule of assessment is clear: defendants and plaintiffs can operate

579 Stapleton, supra note 163; Thompson v Smiths Shiprepairers (North Shields) Ltd, supra note 488. 
under the knowledge that no contribution to risk will be devoid of responsibility; but also that no contribution to risk will lead to greater responsibility than that embodied by that contribution. In terms of consistency, proportionate liability is also relatively strong. The liability of defendant will be consistent across a range of cases; with the assessment process of what constitutes a percentage point of risk capable, to some extent, of assessment. This assessment will never be perfect, but, as courts do assess and deal with complex scientific and actuarial calculations as a matter of course, ${ }^{580}$ such an assessment can utilize similar techniques to those already in use. The consistency of application across all cases, while not perfect, coheres with how law is expressed in other areas of negligence. The pragmatic goals are, especially when compared against competing apportionment rules, relatively well satisfied.

Proportionate liability, while far from ideal, provides a strong basis for apportionment under material contribution to risk. It does closely correspond to the corrective justice mandate of limiting consideration to the rights and responsibilities of the plaintiff and defendant. Proportionate liability does, however, lead to a significant likelihood that plaintiffs will be undercompensated in many cases. The corollary is that defendant deterrence is closely linked to their, and only their, responsibility: a position that is in compliance with corrective justice. The secondary, but important, pragmatic goals each would score proportionate relatively highly, with the inherent logic of proportionate liability applying to proportionate risk underpinning this coherence. Ultimately, proportionate liability is the best apportionment option in terms of corrective justice. When compared to the four other options, proportionate liability best links the novel nature of the harm in material contribution to risk, and the goals of corrective justice. Chapter IV of this thesis

${ }^{580}$ Bert Black \& David Lilienfeld, "Epidemiologic Proof In Toxic Tort Litigation” (1983) 52 Fordham Law Review 732 at 765. 
emphasized that the goals of corrective justice are, and should be, the goals of negligence: so, as the most coherent reification of these goals, proportionate liability is the superior apportionment rule.

\section{F Attempting a Modest Improvement of Proportionate Liability: Adding a Minutiae of Discretion Through an 'Exceptional Exception'}

This brief section attempts to make an original contribution by tailoring proportionate liability to better respond to the needs of material contribution to risk cases, while still being coherent with corrective justice. It is not a requirement that there be a sole rule of apportionment. There is not a sole causal test; nor is there a sole tort. Proportionate liability corresponds relatively well to the requirements placed on it; but not perfectly well. Here, I propose an exception to proportionate liability; in order to potentially redress its most glaring shortcoming: the potential injustice accorded to plaintiffs. As noted at length above; proportionate liability has the potential to leave plaintiffs undercompensated. Material contribution to risk cases in the UK have been observed to be complex ones: Barker featured contributory negligence by the plaintiff; ${ }^{581}$ while Patterson ${ }^{582}$ and Sienkiewic $2^{583}$ had the vast majority of the harm being non-actionable. The law of negligence is not a perfect system; and will never achieve perfect compensation in every case. But, circumstances do arise when alterations to rules are necessary. Material contribution to risk is one such circumstance, and, it may well be that proportionate liability in material contribution cases is another.

${ }^{581}$ Barker v Corus, supra note 246 This contributory negligence is a fact oft-forgotten: including by the Court in Sienkiewicz .

582 Smiths Docks Ltd v Patterson, supra note 276 Where 82 per cent of the risk was contributed by insolvent wrongdoers.

583 Sienkiewiczv Greif (UK) Ltd, supra note 3 Where 83 per cent of the risk was contributed by innocent sources. 
In this section I maintain that proportionate liability should remain as the de facto apportionment rule for material contribution to risk cases; but an exception to this rule should exist. This exception is not a novel one: the vexing nature of a novel apportionment rule was well demonstrated by Green's risk pricing model. ${ }^{584}$ Instead, I propose to give more useful form to the discretionary apportionment rule that, in the above conception, is problematic. Proportionate liability is to be the de facto rule of apportionment: but under my proposed modification, in exceptional cases of injustice, I propose that judicial discretion over damages be permitted.

Obviously, what does, and does not, constitute an 'exceptional case' of injustice is the lynchpin of this concept. By exceptional case, I do not mean cases in which the plaintiff will be radically undercompensated. Such cases are indeed unfortunate; but there is no solution apparent to lead to compensating plaintiffs without ignoring corrective justice conceptions of limited defendant responsibility. This is obviously a part of injustice to the plaintiff, but, without more, making defendants liable over and above their formal responsibility is contrary to both corrective justice bipolarity and defendant deterrence.

\section{The First Limb: Special Injustice to the Plaintiff}

Instead, by 'exceptional injustice', I craft a conjunctive two-limbed test. Both limbs must be satisfied to permit judicial discretion. The first part of this test injustice suffered by the plaintiff. In a material contribution to risk case, if a plaintiff still suffers injustice as a result of being undercompensated, then the first limb of this test will be satisfied.

\footnotetext{
584 S. Green, supra note 13.
} 
In this regard, judicial latitude is obviously necessary. Negligence generally, and causation and apportionment specifically, are riven with fictions. ${ }^{585}$ The law of negligence operates under the fiction that damage awards cost the defendants money, and thus deter them. The reality is that only 6 per cent of the cost of damage awards are paid by defendants; the remainder are paid by the defendants' insurers. ${ }^{586}$ Equally, courts award damages under the view that the plaintiff will be 'made whole' by the damage award. In material contribution to risk cases, such an outcome is an obvious-if useful-fiction. In Patterson, Sienkiewicz \& Barker, the plaintiff had died of their mesothelioma well before arguments on damages were heard. In assessing injustice under this proposed first limb; the injustice is not merely a quantitative one. It is also a qualitative one. Material contribution to risk and proportionate liability are quantitative modes: all risk is eventually determined to be a percentage contribution, with compensation paid to correspond to this responsibility level. In assessing injustice under the proposed model, I assert that judges should frankly assess the injustice in terms of the bipolar nature of corrective justice. If, for example, the damages are going to wards ongoing care; instead of being denunciatory in character, judicial impressions of injustice would likely be more critically engaged.

\section{The Second Limb: Special Moral Wrongdoing by the Defendant}

If a judge is to find that there is injustice in the plaintiff being undercompensated; then, and only then, will the first limb of the test be satisfied. The second limb is also a qualitative one. The second limb looks for a degree of moral blameworthiness that could be used to validly increase the proportion of liability accorded to the wrongdoer. ${ }^{587}$ If the

\footnotetext{
585 James Lee, "Fictions in Tort" in Maksymilian Del Mar \& William Twining, eds, Legal Fictions in Theory and Practice (Cham: Springer International Publishing, 2015) 255.

586 Aatiyah's Accidents and Compensation in the Law, Peter Cane, 8th ed (New York: Cambridge University Press, 2013) at 203.

587 See Heller $v$ Martens, supra note 271.
} 
wrongdoing by the defendant is assessed to be an exceptional divergence from the expected standard of care; then this second limb would be satisfied.

Such an outcome likely still corresponds to corrective justice; and is a very limited occurrence. It pertains to a qualitative assessment of the defendant's wrongdoing. The 'just and equitable' phrasing is not uncommon amongst acts that pertain to contributory negligence. ${ }^{588}$ In assessing what is just and equitable, there has been much consideration of what is, and is not, just, and what factors can be used to determine blameworthiness to constitute an injustice. ${ }^{59}$ This is generally considered in terms of the departure from the standard of care. ${ }^{590}$ Under proportionate liability, the assessment of risk is not determined in terms of such a departure, but is instead assessed in terms of a value-neutral consideration of risk exposure. For example, in mesothelioma cases, the number of asbestos particles that the defendant negligently exposed the plaintiff to is the almost exclusive determinant of the risk. In Canada, the apportionment for contribution between defendants is assessed in terms of contributory fault. ${ }^{591}$ Such a process in material contribution cases may well not be possible. I propose to utilize the schema already used for apportionment between joint and severally liable defendants to be used to determine whether there has been a degree of blameworthiness on the behalf of the defendant in relation to the plaintiff to a level that would satisfy the second limb.

The jurisprudence on establishing comparative blameworthiness is well summed upon in the non-exhaustive list from Heller $v$ Martens. ${ }^{592}$ Langsten $\mathrm{J}$ summarized indicia for comparative blameworthiness thusly:

...Courts have considered such factors as:

\footnotetext{
588 Cheifetz, supra note 325 at 10.

${ }^{589}$ See, for example Honore, supra note 169.

${ }^{590}$ Heller $v$ Martens, supra note 271.

${ }^{591}$ David Cheifetz, supra note 502 at 8.

592 Heller $v$ Martens, supra note 271.
} 
1. The nature of the duty owed by the tortfeasor to the injured person: Aynsley v. Toronto General Hospital, [1968] 1 O.R. 425 at 444-45 (C.A.), affd 197123 (SCC), [1972] S.C.R. 435; Arnold v. Teno, 19782 (SCC), [1978] 2 S.C.R. 287.

2. The number of acts of fault or negligence committed by a person at fault: Bruce v. McIntyre, [1954] 2 D.L.R. 799 (C.A.), affd 19555 (SCC), [1955] S.C.R. 251.

3. The timing of the various negligent acts. For example, the party who first commits a negligent act will usually be more at fault than the party whose negligence comes as a result of the initial fault: Aynsley, supra.

4. The nature of the conduct held to amount to fault. For example, indifference to the results of the conduct may be more blameworthy: Chamberland v.Fleming 19841289 (AB QB), (1984), 12 D.L.R. (4th) 688 (Alta. Q.B.) (where the driver of a motor boat sped by a canoe causing it to tip, and the canoeist to drown). Similarly, a deliberate departure from safety rules may be more blameworthy than an imperfect reaction to a crisis: see John G. Fleming, The Law of Torts, 8th ed. (Sydney: Law Book Company, 1992) at 273-74.

5. The extent to which the conduct breaches statutory requirements. For example, in a motor vehicle collision, the driver of the vehicle with the right of way may be less blameworthy: Crothers v. Northern Taxi (1957), 10 D.L.R. (2d) 87 at 100 (Man. C.A.); see also Clyke v. Blenkhorne (1958), 13 D.L.R. (2d) 293 at 304 (N.S.S.C.).

6. Fault may vary from extremely careless conduct, by which a party shows a reckless indifference or disregard for the safety of persons or property, to a momentary or minor lapse of care in conduct which, nevertheless, carries with it the risk of foreseeable harm. Degrees of contributory negligence are assessed accordingly: Alberta Wheat Poolv. Northwest Pile Driving Ltd. 2000 BCCA 505 , (2000), 80 B.C.L.R. (3d) 153 at 165-66 (C.A.); see also Giuliani v. Saville (1999), 133 B.C.A.C. 164 at 167.593

These six different considerations are not exhaustive, but are highly useful to determine the qualitative blameworthiness that is the gist of the second limb of the test. In determining the initial percentage for which the defendant is liable under a proportionate

593 Ibid, paras 33-35. 
liability apportionment rule, each quotient of risk is regarded as equal: quantity is the almostexclusive criterion. ${ }^{594}$ There is no factoring in of these elements. If using these elements to assess the blameworthiness, a court finds that the contribution to risk by the defendant was exceptionally blameworthy, the second limb will be satisfied, permitting a court to aver to a discretionary apportionment rule. Such an exception looks to the standard of care, quantitative contribution to risk; as well as qualitative blameworthiness.

\section{The Judicial Alteration is Fixated on Defendant Blamewortbiness: Not Plaintiff Compensation}

If, in that truly exceptional case, where material contribution to risk is applied, and the two limbs of the exception to the de facto apportionment scheme is to apply, a Court is still not applying joint and several liability by stealth. Such an outcome, while satisfactory for the plaintiff, does not, and cannot correspond to the bipolarity of corrective justice. Without a reason to collectivize the responsibility of the defendants, the only manner in which to increase the financial liability for a defendant is to alter the assessment of blameworthiness to reflect the quantitative assessment of risk.

A court should undertake an "assessment of relative misconduct from the perspective from standards of reasonable care", 595 and determine whether the defendant's share of the damages should exceed their proportionate contribution to risk. If, for example, the two-limbed exceptional exception is satisfied in a case where a defendant was liable for 30 per cent of the risk; a Court is able to revise their liability to the plaintiff to a level that reflects that their harm was more blameworthy than mere quantitative representation. As with seeking contribution between defendants, blameworthiness here would increase the

\footnotetext{
${ }^{594}$ Jane Stapleton, supra note 6 Obviously, wrongfulness is part of the criterion, with innocent contributions to risk beyond the ambit. .

${ }^{595}$ Lewis Klar, Tort Law, 3rd ed (Toronto: Carswell, 2003) at 374.
} 
percentage; but it would not increase the percentage. In determining contribution between defendants, even if one defendant had egregiously departed from the standard of care, that one defendant would not be liable in full if his fellow defendants were also causally relevant. Rather, that defendant's liability would increase to a level that reflected his blameworthiness. Such an increase would almost never be up to 100 per cent. As a result, plaintiffs, even under this exceptional exception, would still not receive full compensation. Instead, a defendant's liability would reflect their moral wrongdoing. Their blameworthiness does not correlate precisely to their arithmetical contribution to risk. This exceptional exception would permit for the defendant to be liable for more; and as a result, for the plaintiff to be compensated to a greater extent than they would under pure proportionate liability. It would however, be very common for this increased liability to nonetheless be less than full compensation. Within the structure of corrective justice, and the bounds of material contribution to risk, the exceptional discretionary exception to the proportionate liability rule is a modest improvement, given its highly rare application. Nonetheless, the creation of flexibility would allow the proportionate rule of apportionment, when appropriate, to bend without breaking.

\section{F Summary: Apportionment}

This chapter on apportionment was written explicitly with the future reader in mind. This future reader, be they judge, lawyer, academic, or lay person, can and should agree or disagree with my selection in section VIII(E). By surveying the most likely apportionment rules, this section has, at minimum, outlaid what the options are. At most, this section has clearly enunciated a justification for a modified version of proportionate liability to apply to material contribution to risk cases. This modified is the addition of the option of 
discretionary apportionment, but only in truly exceptional cases. This rule of apportionment is the most coherent with corrective justice, and best mirrors the judicial expression of apportionment in difficult cases. The exceptional exception is not a perfect exception. Many, if not most, plaintiffs will find themselves undercompensated. It is worth recalling, however, that in speaking of injustice, the Court in $W$ alker referred to the problematic nature of uncompensated plaintiffs; not undercompensated ones ${ }^{596}$. Determining what constitutes a quotient of risk, and monetizing that quotient, is inherently difficult and problematic. Such issues are, however, not beyond the capacity of courts to adjudicate. This section has outlined, assessed, and critiqued the competing apportionment rules for material contribution to risk. None stood out as inherently superior. Proportionate liability was most coherent; and twinned with an exceptional exception, was able to bend, without breaking, the goals of the law of negligence in order to achieve a rule of apportionment that reflects the true nature of the material contribution to risk inquiry.

596 Walker Estate v York Finch General Hospital, supra note 1, para 88. 


\section{IX: CONCLUSION}

Material contribution to risk stands at a critical juncture. One step in either direction, and it may fall into dishonor, irrelevance, or injustice. This thesis has made its own contribution to leading material contribution to risk along a more purposeful path. Material contribution to risk can have significant contribution to the law of negligence. It can avoid legitimate plaintiffs being denied redress; and can ensure that culpable defendants pay for wrongdoing. It can create a fairer system of negligence wherein plaintiffs aren't tripped at the all-or-nothing compensation barrier. Material contribution to risk can render complexity comprehensible and divisible.

But it can only do so if it takes a coherent form. A clear enunciation of what the law of negligence stands for is necessary. Noting that Canadian approaches are unique; and that Canada is free to shape their own approach to material contribution to risk is an essential part of forming a new path. In its three parts, this thesis has aimed to make three significant contributions in three significantly different areas.

The first part of this thesis was a pragmatic analysis of the theory of tort law. With the latter third of this thesis concerned with assessing parts of material contribution to risk, this first part applied a robust methodology to give assessment criteria for the law of causation. This part concluded that corrective justice does indeed stand as the best account of the law of negligence; and that the achievement of the goals of corrective justice thus provided a sound criteria against which the latter part of this thesis can score competing doctrines.

The second part of this thesis was a comparative one. The Canadian jurisprudence on material contribution to risk is sparse, while the UK jurisprudence is fulsome. This part compared the approach to material contribution to risk in the two jurisdictions to show 
contrasts and commonalities between the two jurisdictions. This part had the purpose of drawing out the status of material contribution to risk from the relatively sparse Canadian jurisprudence. By analyzing the cases in the both jurisdictions that crystallized a significant development in the law of negligence, this section was able to demonstrate that the Canadian jurisprudence, despite its limited enunciation, shows a unique conception of material contribution to risk. This was, and is, a significant recognition. No other Canadian author has undertaken such an analysis; and by doing so here, it has been clearly shown that the Canadian body of law is fundamentally different to the UK body of law. The Canadian body of law is thus not bound to follow a trammeled path, and can instead seek its own. Such a realization is a promising one for the development of material contribution to risk.

The third part clarifies the trigger; and crafts an apportionment rule for material contribution to risk. Neither area has yet seen a satisfactory enunciation in Canada. Material contribution to risk in Canada is still in its relative infancy. It has never been applied by an appellate court; and has been subject to harsh scrutiny, both by the judiciary and the academy. In order to be applied, the circumstances in which material contribution to risk applies in lieu of but-for causal processes must be defined. No judge or commentator has expressed interest in replacing but-for causal analyses with material contribution to risk. The latter is instead considered to be part of the causal array that is only triggered when the de facto tests manifestly fail. Enunciating what constitutes such a circumstance was the core of chapter VIII, which analyzed the trigger, as currently conceived by the Supreme Court in Clements. This section found a definition of the trigger by probing precisely what was said, and was not said, in Clements and other significant cases. Through this close analysis, a picture of the trigger emerged. Rather than one unified trigger; the trigger has two limbs. The first is a 'how' - it is defined by factual circumstances in which the but-for causal processes 
are likely not capable of producing useful results. The second limb is a 'why'-it is defined by reasons for material contribution to be applied. These reasons are coterminous with corrective justice—and center, generally, on injustice to the plaintiff. Only when—or ifboth the how and why are met can material contribution to risk be applied.

The second chapter of this part, chapter VIII, concerned the corollary of applying material contribution to risk: what are the defendants liable for. This section was largely composed of analysis and conjecture. No Canadian case has considered apportionment in material contribution to risk; nor has any Canadian author undertaken a similar task. The UK jurisprudence on apportionment leaves much to be desired; so this section attempted to evaluate the apportionment options that a Canadian Court could utilize. No extant apportionment rule perfectly cohered to the demands placed on it under corrective justice: to solve this, I proposed a modified rule of proportionate liability. The proportionate liability apportionment rule is the de facto test; but in truly exceptional cases, a bounded concept of discretionary apportionment is to apply. This modified rule adheres as closely as possible to the requirements of corrective justice, and should achieve more just outcomes than an unmodified apportionment rule.

In each of the three parts of this thesis, I attempted to bring clarity to the principle of material contribution to risk in Canada. The first part clarified the underlying theory and goals; the second clarified exactly how material contribution to risk is currently conceived; and the third sought to devise a path forward. Each of these parts was a unique one in the literature. Each was written with the ambition of bringing material contribution to risk one step closer to application and understanding. When this moment comes, Canadian negligence law will be one step closer to achieving meaningful justice for all who come before it. 


\title{
BIBLIOGRAPHY
}

\author{
A Legislation \\ Alberta Tortfeasors Act, RSA $2000 \mathrm{c} \mathrm{t}-5$ [Alberta Tortfeasors Act]. \\ Compensation Act, 2006, c 29 [Compensation Act]. \\ Government Employees Compensation Act, RSC 1985, c g-5 [Government Employees Compensation \\ Act . \\ Negligence Act, RSBC 1996 c 333 (British Columbia) [Negligence Act. \\ Workers Compensation Act R.S.B.C. 1996 c. 492 (British Columbia) [Workers Compensation Act \\ R.S.B.C. 1996 c. 492 (British Columbia)].
}

\section{B Jurisprudence}

Allied Maples v Simmons, [1995] 2 WLR 1602 (House of Lords).

Alphacell Ltd v Woodward, [1972] AC 824.

Arndt v Smith, [1997] 2 SCR 539 (SCC).

Arneil v Paterson, [1960] AC 560.

Athey $v$ Leonati, [1995] BCJ (Court of Appeal).

Athey $v$ Leonati, [1996] 3 SCR 258.

Balev Setsam Pty Ltd, [1996] 288 QCA.

Barker v Corus, [2006] 20 UKHL.

Barker v Montford Hospital, [2007] 278 DLR (4th) (Ont CA).

Barker v Saint Gobain Pipelines PLC, [2005] 3 All ER 661.

Bazley v Curry, [1999] 2 SCR 534.

Birkholtzv RJ Gilbertson Pty Ltd, [2985] 38 SASR 121.

Bolton Metropolitan Borough Council v Municipal Mutual Insurance Ltd, [2006] EWCA Civ 50.

Bonnington Castings v Wardlaw, [1956] 613 AC . 
Brown \& Ors v Corus Ltd, [2004] 374 EWCA Civ (UK Court of Appeal).

Brown v Superior Court, [1988] 751 Pacific Reporter 470, Series 2d.

Browning v War Office, 3 All ER 1089.

Buchan v Ortho Pharmaceutical Company (Canada) Ltd, [1984] 46 OR (2d) 113 (Ontario High

Court).

Bulmer v Horsman, [1987] 42 CCLT 220.

Chaplin v Hicks, 2 KB 786.

Chappel v Hart, [1998] 195 CLR 232.

Chesherv Afshar, [2005] 1 AC 134.

Clements v (Litigation Guardian of) Clements, [2010] BCCA 581.

Clements v Clements, [2012] SCC 32.

Cook v Lewis, [1950] 4 DLR 136 (BCCA).

Cook v Lewis, [1951] SCR 830.

Cork v Kirby Maclean, [1952] 2 All ER 402 (House of Lords).

Cottrelle v Gerrard, [2003] 20 CCLT (3d) 1 (Ontario Court of Appeal).

Dingle v Associated Newspapers Ltd, [1961] 2 QB 162.

Dixon v Clement Jones, [2004] EWCA Civ 1005 (Court of Appeal).

Donoghue v Stevenson, 562 AC (1932).

Duke of Buccleuch v Cowan, [1866] 5 Macph 214.

Ediger v Johnston, [2013] 18 SCC .

Employer's Liability Insurance "Trigger" Litigation, [2010] 1096 EWCA CIV , Per Rix LJ.

Fairchild v Glenhaven Funeral Homes, [2002] 22 UKHL (House of Lords).

Fitrgerald v Lane, [1987] 1 QB 781.

Froom v Butcher, [1975] 3 WLR 379. 
Frost v Chief Constable of South Yorkshie Police, [1999] 2 AC 455 (House of Lords).

Fullowka v Royal Oak Ventures, [2008] 4 NWTCA (NWT CA).

G (ED) v Hammer, [2003] SCC 52.

Gardiner v Motherwell Machinery and Scrap Co Ltd, [1961] 1 WLR 1424.

Gemoto v Calgary Regional Health Authority, [2006] ABQB 740 (Alberta Court of Queen's

Bench).

Gregg v Scott, [2005] 2 AC 176.

Hagan v Dalkon Shield Claimants Trust, [1998] 43 CCLT (2d) 11 (Alberta Queens Bench).

Heilv Rankin, [2001] 272 QB (Queen's Bench).

Heller v Martens, [2002] 122 ABCA .

Henegan v Manchester Dry Docks, [2014] 4190 EWHC .

Hole v Hocking, [1962] SASR 128.

Hollis v Birch, [1996] 2 WWR 77.

Hollis v Dow Corning Corp, [1995] 4 SCR 634.

Holtby v Brigham \& Cowan, [2000] 3 All ER 421.

Hotson v Eask Berkshire Area Health Authority, [1987] 750 AC .

Hotson v East Berkshire Health Authority, [1987] 2 All ER 909.

Hymowitz v Eli LIlley \& Co, [1989] 539 North Eastern Reporter 1069, Series 2d.

Jackson v Kelowna General Hospital, [2007] 277 DLR (4th) .

Jordan House Ltd v Menow, [1974] SCR 239.

Joseph Brant Memorial Hospital v Koziol, [1978] 1 SCR 491.

Kauffman v Toronto Transit Commission, 19 DLR (2d) 204.

Kish v Prairie Harvestore Systems Ltd, [1986] 319 Saskatchewan Reporter 30.

Kuwait Airways Corporation v Iraqi Airways Co (Nos 4 and 5), 2 AC 883 (House of Lords). 
Laferriere v Lawson, [1991] 1 SCR 541.

Lindabl Estate v Olsen, 639 ABQB 639 (Alberta Court of Queen's Bench).

Livingstone v Rawards Coal Co, [1888] 5 App Ca 25.

MacDonald (Litigation Guardian of) v Goertr, [2009] 358 BCCA (BCCA).

March v E \& MH Stramare Pty Ltd, [1991] 171 CLR 506.

McGee v National Coal Board, [1973] 1 WLR .

Meyers v Peel County Board of Education, [1981] 1 SCC .

Michalchuk v Yorkton (City), [1987] 54 Saskatchewan Reports 74 (Queens Bench).

Mooney v British Columbia (Attorney General), [2004] 25 CCLT (3d) 234 (British Columbia Court

of Appeal).

Mooney v British Columbia, [2004] BCCA 402.

Mozersky v Cushman, [1997] No 4912 OJ (Ontario General Division).

Newis v Lark, [1571] 75 ER 609.

Nicholson v Atlas Steel Foundry \& Engineering Co, 1 WLR 613 (1957).

Novartis Grimsby Ltd v Cookson, [2007] EWCA Civ 1261.

Palmer et al v Stora Kopparebergs, 16 CCLT 22 (Nova Scotia Supreme Court).

Palsgraf v Long Island Railway Co, 248 NY 339.

Peacock v Mills and the City of Calgary, [1964] 50 WWR 626.

$R v$ Maybin, [2012] 24 SCC .

R v Nette, [2001] 3 SCR 488.

Reiblv Hughes, [1980] 114 DLR .

Resurfice Corp v Hanke, [2007] 7 SCC.

Rutherford v Owens-Illinois Inc, 67 Cal Rptr 16, Series 2d (1997).

Rylands v Fletcher, [1868] 1 UKHL (House of Lords). 
Sahourin Estate v Watterodt Estate, [2005] 34 CCLT (3d) 193 (British Columbia Court of Appeal).

Sam v Wilson, [2007] BCCA 622.

Saunders System Birmingham Co v Adams, [1928] 217 Alabama Law Reports 621.

Seatle v Purvis, [2007] 47 CCLT (3d) 179 (BCCA).

Sienkiewiczv Greif (UK) Ltd, [2011] 10 UKSC (UK Supreme Court).

Sindell v Abbott Laboratories, 607 Pacific Reporter 924, Series 2d (1980).

Smith v Knudsen, [2004] BCCA 613.

Smith v Leech Brain \& Co, [1961] 3 All ER 1159.

Smith v Rapid Transit, 317 Massachussets Law Reports 469.

Smiths Docks Ltd v Patterson, [2006] 20 UKHL.

Snell v Farrell, [1990] 72 DLR (4th) 289.

Sobalv Brar, [1998] 3 WWR 553 (Alberta Queens Bench).

St-Jean v Mercier, [2002] 2 SCR 491.

Stefanshyn v Rubin, [1997] 2 WWR 298 (Manitoba Court of Appeal).

Summers v Tice, [1948] 199 Pacific Reporter Series 2d 1.

T(G) v Griffiths, 2 SCR 570 (1999).

Thompson v Smiths Shiprepairers (North Shields) Ltd, [1984] 405 QB .

Walker Estate v York Finch General Hospital, 1 SCR 647 (2001).

Ward v V ancouver (City), [2010] 2 SCR 28.

Whiten v Pilot Insurance Co, [2002] 1 SCR 595.

Wilsherv Essex Area Health Authority, [1988] 1074 AC .

Wilson v Bird Ltd, [1963] 2 SA 508.

Yorkshire Dale Steamship Company Ltd v Minister of War Transport, [1942] 691 AC . 
Zaba v Sasktatchewan Insitute of Applied Science and Technology, [1997] 8 WWR 414 (Saskatchewan Court of Appeal).

\section{Secondary Material: Monographs}

Aatiyah, Patrick. The Rise and Fall of Freedom of Contract (Oxford: Oxford University Press, 1979).

Aatiyah's Accidents and Compensation in the Law. Peter Cane, 8th ed (New York: Cambridge University Press, 2013).

Allan Beever. Rediscovering the Law of Negligence (Oxford: Hart Publishing, 2007).

Allen Linden \& Bruce Feldthusen. Canadian Tort Law, 10th ed (Toronto: LexisNexis

Publishing, 2015).

Ariel Porat, Alex Stein. Tort Liability Under Uncertainty (Oxford: Oxford University Press, 2001).

Aristotle: Nicomachean Ethics: Translation, Introduction and Commentary, translated by Sarah

Broadie \& Christopher Rowe (Oxford: Oxford University Press, 2002).

Austin, John. The Province of Jurisprudence Determined (London: John Murray, 1832).

Australia et al. Review of the law of negligence: first report. ([Canberra]: Commonwealth of Australia, 2002).

Benedikt Kahmen, Markus Stepanians, ed. Critical Essays on "Causation and Responsibility"

(Berlin: DeGruyter, 2013).

Brenda Heelan Powell. Uncertain Risk, Causation, and Precaution in Toxic Tort Litigation (Master of Laws Thesis, University of British Columbia, 1999) [unpublished].

Calabresi, Guido. The Costs of Accidents: A Legal and Economic Analysis (New Haven: Yale University Press, 1970). 
Cane, Peter \& Mark Tushnet. Oxford Handbook of Legal Studies, 2d ed (Oxford: Oxford University Press, 2003).

Coleman, Jules L. Markets, Morals, and the Law (Oxford University Press, 1988).

Coleman, Jules. Risks and Wrongs (Cambridge: Cambridge University Press, 1992).

Constitution, Great Britain: Parliament: House of Lords: Select Committee on the. Fast-track Legislation: Constitutional Implications and Safeguards, 15th Report of Session 2008-09, Vol. 2: Evidence (London: The Stationery Office, 2009).

Cranor, Carl F. Regulating Toxic Substances: A Philosophy of Science and the Law (Oxford University Press, 1993).

Danuta Mendelson. The Interfaces of Medicine and Law (Aldershot: Darmouth Publishing, 1998). David Cheifetz. Apportionment of Fault in Tort (Toronto: Canada Law Book Ltd, 1981).

Del Mar, Maksymilian \& William Twining, eds. Legal Fictions in Theory and Practice, Law and Philosophy Library (Cham: Springer International Publishing, 2015).

Dickson, Brice \& Gavin Drewry. The Judicial House of Lords: 1876-2009 (OUP Oxford, 2009). Don Dewees, David Duff \& Michael Trebilcock. Exploring the Domain of Accident Law (New York: Oxford University Press, 1996).

Donald Harris et al. Compensation and Support for Illness and Injury (Oxford: Clarendon Press, 1984).

Dworkin, Ronald. Law's Empire (Cambridge: Harvard University Press, 1986).

Edenhofer, Ottmar \& Intergovernmental Panel on Climate Change, eds. Climate change 2014: mitigation of climate change: Working Group III contribution to the Fifth assessment report of the Intergovernmental Panel on Climate Change (New York, NY: Cambridge University Press, 2014). Englard, Izhak. Corrective and Distributive Justice (Oxford: Oxford University Press, 2009). 
Ernest Weinrib. Tort Law: Cases and Materials (Toronto: Edmond Montgomery Publications, 2009).

Evans, Alfred S. Causation and Disease (Boston, MA: Springer US, 1993).

Farnsworth, Ward. The Legal Analyst (Chicago: University of Chicago Press, 2007).

Feldthusen, Bruce \& Allen Linden. Canadian Tort Law (Markham: LexisNexis Publishing, 2006).

Finnis, John. Natural Law and Natural Rights, 2nd ed (Oxford: Oxford University Press, 2011).

Fleming, John. An Introduction to The Law of Torts, 2nd ed (Oxford: Clarendon, 1977).

Fleming, John. The Law of Torts, 8th Ed ed (London: Thomson Reuters, 1992).

Freeman, Michael. Lloyd's Introduction to Jurisprudence, 9th ed (London: Sweet \& Maxwell, 2014).

Fridman, Gerald. The Law of Torts, 3rd ed (Toronto: Carswell, 2010).

Fuller, Lon. The Morality of Law, Revised Ed ed (New Haven: Yale University Press, 1964).

Gerhard Wagner, ed. Tort Law and Liability Insurance (New York: Springer International, 2011).

Glanville Williams. Joint Torts and Contributory Negligence (London: Stevens \& Sons, 1951).

Gregory S Pun, Margaret Hall. The Law of Nuisance in Canada (Markham: LexisNexis

Publishing, 2010).

Harpwood, Vivienne. Modern Tort Law, 7th ed ed (Oxford: Routledge, 2009).

Hart, HLA. The Concept of Law, 2nd ed (New Haven: Yale University Press, 1994).

Holmes Jnr, Oliver Wendell. The Common Law (Boston: Little, Brown and Company, 1881).

Honore, Tony \& HLA Hart. Causation in the Law, 1st ed (Oxford: Oxford University Press, 1959). 
Honore, Tony. Responsibility and Fault (Oxford: Hart Publishing, 2009).

Howe, Mark, ed. The Correspondence of Mr. Justice Holmes \& Sir Frederick Pollock 1874-1932

(London: Cambridge University Press, 1942).

Jaap Spier, ed. The Limits of Expanding Liability (The Hague: Kluwer Law, 1998).

James Lee, ed. From House of Lords To Supreme Court: Judges, Jurists, and The Process of Judging

(Oxford: Hart Publishing, 2011).

Jane Stapleton. Product Liability (London: Butterworths, 1994).

Jeremy Holder, ed. Oxford Essays In Jurisprudence, Fourth Series (Oxford: Oxford University

Press, 2000).

John Butler, ed. International Reinsurance: Asbestos Claims (London: Kluwer Law, 1988).

Ken Cooper-Stephenson, Elaine Gibson. Tort Theory (North York: Captus Press, 1993).

Kenneth Abraham. The Forms and Functions of Tort Law (Westbury: Foundation Press, 1997).

Klar, Lewis. Tort Law, 3rd ed (Toronto: Carswell, 2003).

Landes, William \& Richard Posner. The Economic Structure of Tort law (Boston: Harvard University Press, 1987).

Levmore, Saul, ed. Foundations of tort law, Interdisciplinary readers in law (New York: Oxford University Press, 1994).

Louisell, D \& H Williams. Medical Malpractice (Toronto: LexisNexis Publishing, 1973).

Lucy, William. Philosophy of Private Law (New York: Oxford University Press, 2007).

Lynda Collins, Heather McLeod-Kilmurray. The Canadian Law of Toxic Torts (Toronto:

Thomson Reuters, 2014).

M Stuart Madden, ed. Exploring Tort Law (New York: Cambridge University Press, 2005).

Marshall S Shapo. Basic Principles of Tort Law, Hornbook Series (St Paul: West Group, 1999). 
Moore, Michael S. Causation and Responsibility: An Essay in Law, Morals, and Metaphysics (OUP Oxford, 2010).

Osborne, Philip. The Law of Torts, 4th ed (Toronto: Irwin Publishing, 2011).

Owen, David G. Philosophical Foundations of Tort Law (Clarendon Press, 1995).

Patterson, Dennis, ed. A Companion to Philosophy of Law and Legal Theory (Cambridge, Massachusetts: Blackwell, 1996).

Peel, WE \& James Goudkamp, eds. Winfield \& Jolowicz, on Tort, 19th ed (London: Sweet \& Maxwell, 2013).

Peter Cane, Jane Stapleton, ed. The Law Of Obligations: Essays in Celebration of John Fleming (Oxford: Clarendon Press, 1998).

Peter Cane. The Anatomy of Tort Law (London: Hart Publishing, 1997).

Peter Gerhart. Tort Law and Social Morality (New York: Cambridge University Press, 2010).

Pound, Roscoe. Social control through law (Transaction Publishers, 1942).

Poydner, John. Literary Extracts (London: Smith, Elder and Co, 1844).

Prosser, William. The Law of Torts, 4th ed ed (West Publishing Co, 1971).

Raz, Joseph. The Authority of Law: Essays on Law and Morality (OUP Oxford, 2009).

Richard Goldberg, ed. Perspectives On Causation (Oxford: Hart Publishing, 2011).

Richardson, Janice \& Erika Rackley, eds. Feminist Perspsectives on Tort Law (New York:

Routledge, 2012).

Robert L Rabin, Stephen D Sugarman, ed. Torts Stories (New York: Foundation Press, 2003). Sappideen, Caroline \& Prue Vines, eds. Fleming's The Law of Torts, 10th ed (Sydney: Lawbook Co, 2011).

Sheila McLean, ed. Law Reform and Medical Injury Litigation (Aldershot: Dartmouth Publishers, 1995). 
Siltala, Raimo. A Theory of Precedent: From Analytical Positivism to a Post-analytical Philosophy of Law (Hart Publishing, 2000).

Smith, Stephen. Contract Theory, 1st ed (Oxford: Clarendon Press, 1993).

Stephen GA Pitel, Jason W Neyers \& Erika Chamberlain, eds. Tort Law: Challenging Orthodoxy

(Oxford: Hart Publishing, 2013).

Steven Shavell. Economic Analysis of Accident Law (Cambridge: Harvard University Press, 1987).

Sugarman, Stephen D. A New Approach to Tort Doctrine: Taking the Best from the Civil Law and Common Law of Canada (Butterworths, 2003).

Susan A Tacon. Tort Liability in Collective Bargaining Regime (Toronto: Butterworths, 1980).

The Roots of Political Philosophy: Ten Forgotten Socratic Dialogues, translated by Thomas Pangle (Ithica: Cornell University Press, 1987).

Thomas Koenig, Michael Rustad. In Defence of Tort Law (New York: New York University Press, 2001).

Tom Christoffel, Stephen P Teret. Protecting the Public: Legal Issues in Injury Prevention (New York: Oxford University Press, 1993).

Tort and Insurance Law : Proportional Liability : Analytical and Comparative Perspectives

(Hawthorne, NY, USA: Walter de Gruyter, 2013).

Ulrich Magnus, ed. Unification of Tort Law (The Hague: Kluwer Law International, 2001).

Weinrib, Ernest. The Idea of Private Law (Cambridge, Massachusetts: Harvard University

Press, 1995).

Wigmore, John Henry. Select Cases on the Law of Torts (Boston: Little, Brown and Company, 1912).

Wright, Edward. National Trends in Personal Injury Litigation: Before and After "Tpp". 


\section{Secondary Material: Articles}

Acciarri, Hugo A, Andrea Castellano \& others. "On Causal Apportioning and Efficiency in

Tort Law” (2008) Berkeley Program in Law \& Economics, online:

$<$ http://escholarship.org/uc/item/0gw2g5x3.pdf> .

Act, Negligence. “LAW INSTITUTE” (2013), online:

<http://papers.ssrn.com/sol3/papers.cfm?abstract_id=2249217>.

Alberts, Laurie. "Causation in Toxic Tort Litigation: Which Way Do We Go, Judge” (2001)

12 Vill Envtl LJ 33.

Alexander, Larry \& Alexander Ferzan. "Confused Culpability, Contrived Causation, and the Collapse of Tort Theory" in John Oberdiek, ed, Philosophical Foundations of the Law of Torts

(Oxford: Oxford University Press, 2014) 406.

Alexander, Larry A. “Causation and corrective justice: does tort law make sense?” (1987) 6:1

Law and Philosophy 1.

Allan Beever. "Cause-in-Fact: Two Steps out of the Mire" (2001) 51 University of Toronto Law Journal 327.

Altman, Morris. "A behavioral model of path dependency: the economics of profitable inefficiency and market failure” (2000) 29:2 The Journal of Socio-Economics 127.

Andrew F Popper. “In Defense of Deterrence” (2011) 75:1 Albany Law Review 181.

Aristotle. Nicomachean Ethics (350AD).

Barro, Robert J. "Voodoo multipliers" (2009) The Economists' Voice February, online:

<http://is.muni.cz/el/1456/jaro2010/MPE_NKMA/um/12874298/BarroBE2009.pdf>.

Bentham, Jeremy \& Ross Harrison. "A Fragment on Government" in A Fragment on

Government, Cambridge Texts in the History of Political Thought (Cambridge University

Press, 1988). 
Bertrand Russell. "On The Notion of Cause” (1913) 13:6 Proceedings of the Aristotelian Society 190.

Black, Bert \& David Lilienfeld. "Epidemiologic Proof In Toxic Tort Litigation” (1983) 52

Fordham Law Review 732.

Black, V. "Review of L Koury: Uncertain Causation in Medical Liability" (2008) 47 Canadian Business Law Journal 141.

Bone, Robert G. "Lon Fuller's Theory of Adjudication and the False Dichotomy Between Dispute Resolution and Public Law Models of Litigation” (1995) 75 BuL REv 1273.

Boodman, M. “The Malaise of Mass Torts” (1994) 20 Queen’s Law Journal 213.

Boston, Gerald W. “Toxic Apportionment: A Causation and Risk Contribution Model” (1995) 25 Envtl L 549.

Botterell, Andrew \& Christopher Essert. "Normativity, Fairness, and the Problem of Factual Uncertainty" (2009) 47 Osgoode Hall LJ 663.

Bradley, Lewis. "Plato’s Minos” (2006) 60:1 The Review of Metaphysics 17.

Brenda Heelan Powell. "Cause For Concern" (199AD) 9 Journal of Environmental Law and Practice 227.

Broadbent, Alex. "Fact and Law in the Causal Inquiry" (2009) 15 Legal Theory 173.

Brown, Russell. "Still Crazy after all These Years: Anns, Cooper v. Hobart and Pure Economic Loss” (2003) 36 U Brit Colum L Rev 159.

Cairns, Huntington. “What is Law” (1970) 27 Wash \& Lee L Rev 193.

Cane, Peter. "Distributive justice and tort law" (2001) NZL Rev 401.

CE Miller. "Causation In Personal Injury: Legal or Epidemiological Common Sense” (2006) 26:No 4 Legal Studes 544. 
Celli Jr, Andrew G. "Toward a Risk Contribution Approach to Tortfeasor Identification and Multiple Causation Cases” (1990) 65 NYUL Rev 635.

Chamberlain, Erika. "Tort Claims for Failure to Protect: Reasons for (Cautious) Optimism Since Mooney" (2012) 75 Sask L Rev 245.

Cheifetz, David. "The Snell Inference and Material Contribution: Defining the Indefinable And Hunting The Causal Snark” (2002) 30:1 Advocates' Quarterly 1.

Cheifetz, David. The Resurfice Exception: Causation in Negligence Without Probability (2012).

Cheng, Patricia W. "Separating Causal Laws from Casual Facts: Pressing the Limits of Statistical Relevance" in Douglas L Medin, ed, Psychology of Learning and Motivation (Academic Press, 1993) 215.

Christophers, Brett. "On voodoo economics: theorising relations of property, value and contemporary capitalism” (2010) 35:1 Transactions of the Institute of British Geographers 94.

Clermont, KM \& E Sherwin. “A Comparative View of Standards of Proof” (2002) 50 American Journal of Comparative Law 243.

Coase, Robert. “The Problem of Social Cost” (1960) 3 Journal of Law \& Economics 1. Coleman, Jules L. "Mixed Conception of Corrective Justice, The" (1991) 77 Iowa L Rev 427. Collins, Lynda Margaret \& Heather C McLeod-Kilmurray. "Material Contribution to Justice? Toxic Causation after Hanke v. Resurfice” (2011) Toxic Causation after Hanke v Resurfice (July 1, 2011), online: <http://papers.ssrn.com/sol3/papers.cfm?abstract_id=1883714>. Collins, Lynda. "Causation, Contribution and Clements: Revisiting the Material Contribution Test in Canadian Tort Law” (2011) 19 Tort Law Review 86.

Conaghan, Joanne. “Tort law and feminist critique” (2003) 56:1 Current Legal Problems 175. Cover, Robert. "Nomos and Narrative" (1983) 97 Harvard Law Review 4. 
Cowan, Thomas A. "Rule or Standard in Tort Law" (1958) 13 Rutgers L Rev 141.

Credit, Consumer. "Commercial Property” (2007) Business Law Review 253.

Croley, Steven P \& Jon D Hanson. “The Nonpecuniary Costs of Accidents: Pain-and-

Suffering Damages in Tort Law” (1995) 108:8 Harvard Law Review 1785.

Crowne, Emir \& Omar Ha-Redeye. "Clements v. Clements: A material contribution to the jurisprudence-The Supreme Court of Canada clarifies the law of causation" (2012) 2:2

University of Western Ontario Journal of Legal Studies, online:

<http://papers.ssrn.com/sol3/papers.cfm?abstract_id=2097881>.

Culp, Jerome M. "Causation, Economists, and the Dinosaur: A Response to Professor

Dray" (1986) 49:3 Law and Contemporary Problems 23.

David Cheifetz. More adventuring with scholars, philosophers, and me (2015).

David, Hillel, W Paul McCague \& Peter F Yaniszewski. "Proving Causation Where the but for Test Is Unworkable” (2005) 30 Advoc Q 216.

Dawid, Alexander Philip. "Statistical Evidence for Causality" in Perspectives on Causation (Oxford: Hart, 2011) 134.

Debora L Threedy. “Legal Archaeology: Excavating Cases, Reconstructing Context” (2005) 80 Tul L Rev 1197.

Derrida, Jacques \& F C T Moore. "White Mythology: Metaphor in the Text of Philosophy" (1974) 6:1 New Literary History 5.

Donal Nolan. "Causation and the Goals of Tort Law" in Andrew Robertson \& Tang Hang Wu, eds, The Goals of Private Law (London: Hart, 2009) Ch. 7.

Dworkin, Ronald. "Natural Law Revisited” (1981) 34 U Fla L Rev 165.

Easterbrook, Frank H. “Judicial Discretion in Statutory Interpretation” (2004) 57 Okla L

Rev 1. 
Edward Veitch. "The Many Facets of Cook v Lewis” (2010) 61 University of New

Brunswick Law Journal 287.

Epstein, Richard A. "Causation and corrective justice: a reply to two critics" (1979) The Journal of Legal Studies 477.

Evans, Alfred S. "Causation and disease: the Henle-Koch postulates revisited" (1976) 49:2

The Yale journal of biology and medicine 175.

Fiksel, Joseph. "De Minimis Risk" in Chris Whipple, ed, De Minimis Risk, Contemporary

Issues in Risk Analysis 2 (Springer US, 1987) 3.

Fischer, David A. “Tort recovery for loss of a chance” (2001) 36 Wake Forest L Rev 605.

Fletcher, George. "Fairness and Utility in Tort Law Theory" (1972) 85 Harvard Law Review 537.

Fowler, Robert Ludlow \& Roscoe Pound. “The New Philosophies of Law” (1914) 27:8

Harvard Law Review 718.

Fuller, Lon L. "Positivism and Fidelity to Law: A Reply to Professor Hart" (1958) 71:4

Harvard Law Review 630.

Fumerton, Richard \& Ken Kress. "Causation and the Law: Preemption, Lawful Sufficiency, and Causal Sufficiency” (2001) 64 Law and Contemp Probs 83.

Gardner, John. "What is Tort Law For? Part 1. The Place of Corrective Justice” (2011) 30:1

Law and Philosophy 1.

Geistfeld, Mark. "The Doctrinal Unity of Alternative Liability and Market Share Liability" 155 University of Pennsylvania Law Review 447.

Gerald Boston. “Apportionment of Harm in Tort Law: A Proposed Restatement” (1995) 21:2 University of Dayton Law Review 267. 
Gold, Steve. "Causation in Toxic Torts: Burdens of Proof, Standards of Persuasion, and Statistical Evidence” (1986) 96:2 The Yale Law Journal 376.

Goldberg, John. "Unloved: Tort in the Modern Legal Academy” (2002) 55 Vanderbilt Law Review 1501.

Goodman, John C. "Economic Theory of the Evolution of Common Law, An" (1978) 7 J Legal Stud 393.

Gouinlock, James. "What is the Legacy of Instrumentalism? Rorty's Interpretation of Dewey" (1990) 28:2 Journal of the History of Philosophy 251. Green, Leon. “Tort Law Public Law in Disguise I” (1959) 38 Tex L Rev 1.

Green, S. “The risk pricing principle: a pragmatic approach to causation and apportionment of damages" (2005) 4:3 Law, Probability and Risk 159.

Greenberg, Peter. “The Cause of Disease and Illness" in Ian Freckleton, ed, Causation In Law And Medicine (Dartmouth: Ashgate Publishing) 38.

Grossman, Sanford J \& Oliver D Hart. “Takeover Bids, The Free-Rider Problem, and the Theory of the Corporation" (1980) 11:1 The Bell Journal of Economics 42.

H Brink-Roby. "Siren Canora: The Mermaid and the Mythical in Late Nineteenth-Century Science" (2008) 35:1 Archives of natural history 1.

Hammitt, James, Stephen Carroll \& Daniel Relles. "Tort Standards and Jury Decisions" (1985) 14:3 Journal of Legal Studies 751.

Hart, H L A. "Positivism and the Separation of Law and Morals" (1958) 71:4 Harvard Law Review 593.

Hoffman, Lord. "Causation" in Richard Goldberg, ed, Perspectives on Causation (Oxford: Hart Publishing, 2011) 3. 
Hogg, Martin A. "Re-establishing Orthodoxy in the Realm of Causation” (2007) 11

Edinburgh L Rev 8.

Hogg, Martin. "Developing Causal Doctrine" in Richard Goldberg, ed, Perspectives on Causation (Oxford: Hart Publishing, 2011) 40.

Honore, Tony. "Causation and Disclosure of Medical Risks" (1998) 114 Law Quarterly

Review 52.

Jane Stapleton. “The Gist of Negligence: Part II” (1984) 104 LQR 389.

Jones, Craig. "Reasoning through Probabilistic Causation in Individual and Aggregate

Claims: The Struggle Continues” (2011) 39 Advoc Q 18.

Kahn-Freund, O. “On Uses and Misuses of Comparative Law” (1974) 37:1 The Modern

Law Review 1.

Kanai, Ryota, Vincent Walsh \& Chia-huei Tseng. "Subjective discriminability of invisibility:

A framework for distinguishing perceptual and attentional failures of awareness" (2010) 19:4

Consciousness and Cognition 1045.

Kaye, David. "The Limits of the Preponderance of the Evidence Standard: Justifiably Naked Statistical Evidence and Multiple Causation” (1982) 7:2 Law \& Social Inquiry 487.

Keating, Gregory C. "Distributive and corrective justice in the tort law of accidents" (2000)

74:193 Southern California Law Review, online:

<http://papers.ssrn.com/sol3/papers.cfm?abstract_id=269347>.

Keeton, Page, W. "Negligence, Duty, and Causation in Texas” (1932) 16 Tex L Rev 1.

Kennedy, Duncan. "Form and Substance in Private Law Adjudication" (1976) 89:8 Harvard

Law Review 1685.

Knutsen, Erik S. “Ambiguous Cause-in-Fact and Structured Causation: A Multi-

Jurisdictional Approach" (2003) 38 Tex Int'l LJ 249. 
Lansing, RB. "The Motherless Calf, Aborted Cow Theory of Causation” (1984) 15 Env Law.

Lee, James. "Fictions in Tort" in Maksymilian Del Mar \& William Twining, eds, Legal Fictions in Theory and Practice (Cham: Springer International Publishing, 2015) 255.

Leiter, Brian. "Beyond The Hart-Dworkin Debate: The Methodology Problem in Jurisprudence” (2003) 48 American Journal of Jurisprudence 17.

Ligertwood, A \& G Edmond. "Expressing evaluative forensic science opinions in a court of law” (2012) 11:4 Law, Probability and Risk 289.

Lucy, William. "Method and Fit: Two Problems for Contemporary Philosophies of Tort Law” (2007) 52 McGill LJ 605.

Lynda Collins. "Material Contribution To Risk and Causation in Toxic Torts" (2001) 11 Journal of Environmental Law and Practice 105.

Lynda M Collins, Heather McLeod-Kilmurray. "Material Contribution to Justice? Toxic Causation after Resurfice Corp v Hanke” (2010) 48 Osgoode Hall Law Journal 411. MacCoun, Robert J. "Differential Treatment of Corporate Defendants by Juries: An Examination of the 'Deep-Pockets’ Hypothesis” (1996) 30:1 Law \& Society Review 121. Malone, Wex. "Ruminations on Cause In Fact” (1956) 6 Stanford Law Reivew 60. Marsh, Robert. "What is Law?” in Anthony Walsh \& Craig Hemmens, eds, From Law to Order: The Theory And Practice of Law and Justice (Lanham: American Correctional Association) 1. Martin Stone. "On the Idea of Private Law" (1996) 9 The Canadian Journal of Law and Jurisprudence 235 .

McInnes, Mitchell. "Causation in Tort Law: A Decade in the Supreme Court of Canada" (2000) 63 Sask L Rev 445. 
Memmert, Daniel. 'The effects of eye movements, age, and expertise on inattentional blindness" (2006) 15:3 Consciousness and Cognition 620.

Meyer, Jan H F \& Ray Land. “Threshold concepts and troublesome knowledge” (2005) 49:3 Higher Education 373.

Mildred, Mark. "Loss of a Chance in Clinical Negligence: Policy Carries the Day" (2005) 14 Nottingham LJ 54.

Miller, C. "Gregg v. Scott: loss of chance revisited” (2006) 4:4 Law, Probability and Risk 227. Milward (ed) (1689), "Equity" as found in, R. in MB Evans \& RI Jack, eds, Sources of English and Constitutional History (Sydney: Butterworths, 1984).

Mirandola, Salvatore. "Lost Chances, Cause-in-Fact, and Rationality in Medical Negligence" (1992) 50 U Toronto Fac L Rev 258.

Moore, Michael. "For What Must We Pay - Causation and Counterfactual Baselines” (2003) 40 San Diego L Rev 1181.

Moore, Stephen R \& Bianca Matrundola. “The Supreme Court of Canada and the law of causation” (2007) 3rd Annual Update Personal Injury Law and Practice Osgoode Professional Development CLE, online: <http://www.blaney.com/sites/default/files/article_law-of-causation.pdf>. Morris, John. “The Proper Law of a Tort” (1950) 64 Harv L Rev 881. N Pennington \& R Hastie. "A Cognitive Theory of Juror Decision Making: A Story Model” (1991) 13 Cardozo Law Review 519.

Nash, Kerry \& S R Moore. "The Supreme Court of Canada and the law of causation revisited again” (2010) 6th Annual Update Personal Injury Law and Practice, online: <http://www.blaney.com/sites/default/files/SupremeCourtofCanadaandLawofCausationR evisitedAgain_KNash_SMoore_RWinsor.pdf>. 
Nilsson, Robert. "De Minimus Non Curat Lex - Virtual Thresholds for Cancer Initiation by Tobacco Specific Nitrosamines - Prospects for Harm Reduction by Smokeless Tobacco" (2006) 19:1 International Journal of Occupational Medicine and Environmental Health, online: <http://www.degruyter.com/view/j/ijmh.2006.19.issue-1/v10001-006-0004y/v10001-006-0004-y.xml>.

NP Gravells. “Three Heads of Contributory Negligence” (1977) 93 LQR 581.

O’Meally, John Lawrence. “Asbestos Litigation in New South Wales” (2007) 15 JL \& Pol'y 1209.

Palmer, Geoffrey. "New Zealand's Accident Compensation Scheme: Twenty Years on” (1994) 44:3 The University of Toronto Law Journal 223.

Perry, Stephen R. "Moral Foundations of Tort Law, The” (1991) 77 Iowa L Rev 449.

Peter Cane. "Corrective Justice and Correlativity in Private Law" (1996) 16 Oxford Journal of Legal Studies 471.

Pincus, Stephen. "Progress On the Causal Chain Gang: Some Approaches to Causation in Tort Law and Steps Toward a Linguistic Analysis” 24 Osgoode Hall Law Journal 961.

Porat, Ariel \& Alex Stein. "Indeterminate Causation and Apportionment of Damages: An Essay on Holtby, Allen, and Fairchild” 23:4 Oxford Journal of Legal Studies 667.

Posner, Richard A. "The concept of corrective justice in recent theories of tort law" (1981) The Journal of Legal Studies 187.

Postema, Gerald. "Positivism and the Separation of Realists from their Skepticism: Normative Guidance, The Rule of Law, and Legal Reasoning" in Peter Cane, ed, The HartFuller Debate in the Twenty-First Century (Portland: Hart Publishing, 2010) 259.

Priaulx, Nicky. "Endgame: On Negligence and Reparation for Harm” in Janice Richardson \& Erika Rackley, eds, Feminist Perspectives on Tort Law (New York: Routledge, 2012) 36. 
Priest, George L. "The Current Insurance Crisis and Modern Tort Law" (1987) 96:7 The Yale Law Journal 1521.

Raz, Joseph. "Formalism and the Rule of Law" in Robert George, ed, Natural Law Theory (Oxford: Clarendon Press, 1992) 309.

Rendleman, Doug. "Inadequate Remedy at Law Prerequisite for an Injunction, The” (1980) 33 U Fla L Rev 346.

Reynolds, LA. “The Era Of Jurisprudence: Investigating the Relationship Between Science, Law and The Environment" (1995) 9 Canadian Journal of Administrative Law \& Practice 61.

Rhee, Robert J. A Financial Economic Theory of Punitive Damages, SSRN Scholarly Paper ID 1967934 (Rochester, NY: Social Science Research Network, 2012).

Richard Goldberg. "Epidemiological Uncertainty, Causation, and Drug Product Liability" (2014) 59 McGill Law Journal 777.

Ripstein, Arthur \& Benjamin Zipursky. "Corrective Justice in an Age of Mass Torts" in Philosophy and The Law of Torts (Cambridge, UK: Press Syndicate, 2001) 214.

Ripstein, Arthur. "Tort Law in a Liberal State” (2007) 1:2 Journal of Tort Law, online: <http://www.degruyter.com/view/j/jtl.2007.1.2/jtl.2007.1.2.1049/jtl.2007.1.2.1049.xml>. Robert Cover. “The Folktales of Justice: Tales of Jurisdiction” (1985) 14 Capital University Law Review 179.

Robertson, A. "On the Function of the Law of Negligence" (2013) 33:1 Oxford Journal of Legal Studies 31.

Robertson, Andrew. "Rights, Pluralism and the Duty of Care" in Donal Nolan \& Andrew Robertson, eds, Rights and Private Law (Portland: Hart Publishing, 2011) 436.

Robertson, David W. “Common Sense of Cause in Fact” (1996) 75 Tex L Rev 1765. 
Ronen Perry. "The Third Form of Justice, Critical Notice: Corrective and Distributive Justice: From Aristotle to Modern Times by Ishak Englard” (2010) 23 Canadian Journal of Law and Jurisprudence 233.

Sameul Issacharoff. "Mass Torts and Aggregate Asbestos Litigation after Amchem and Orbitz” (2000) 80 Tex L Rev 1925.

Sarah Green. “Winner Takes All” (2004) 120 Law Quarterly Review 566.

Scherpe, Jens M. “A NEW GIST?” (2006) 65:03 The Cambridge Law Journal 487.

Schroeder, Christopher H. "Corrective Justice and Liability for Increasing Risks" (1989) 37

UCLA L Rev 439.

Schwartz, Gary T. "Hidden and Fundamental Issue of Employer Vicarious Liability, The" (1995) 69 S Cal L Rev 1739.

Shapo, Marshall \& American Bar Association. Towards A Jurisprudence of Injury: The Continuing Creation of Substantive Justice in American Tort Law (American Bar Association, 1984).

Shavell, Steven. "Strict liability versus negligence" (1980) The Journal of Legal Studies 1.

Sheinman, Hanoch. "Tort Law and Corrective Justice” (2003) 22:1 Law and Philosophy 21. Simons, Daniel J. “Attentional capture and inattentional blindness” (2000) 4:4 Trends in cognitive sciences 147 .

Smith, Donna. "Increased Risk of Harm: A New Standard for Sufficiency of Evidence of Cauation in Medical Malpractice Cases” (1985) 65 Boston University Law Review 275. Stanley Yeo. "Giving Substance to Legal Causation" (2000) 29 Criminal Reports (Articles) 215.

Stapleton, J. “An 'Extended But-For' Test for the Causal Relation in the Law of Obligations” (2015) Oxford Journal of Legal Studies, online: <http://ojls.oxfordjournals.org/cgi/doi/10.1093/ojls/gqv005>. 
Stapleton, Jane. “Choosing What We Mean by 'Causation’ in the Law” (2008) 73:2 Missouri Law Review 433.

Stapleton, Jane. "Factual Causation, Mesothelioma, and Statistical Validity" (2012) 128 Law

Q Rev 221.

Stapleton, Jane. "Legal Cause: Cause-in-Fact and the Scope of Liability for Consequences" (2001) 54 Vand L Rev 941.

Stapleton, Jane. "Scientific and Legal Approaches to Causation" in Ian Freckleton, ed, Causation In Law And Medicine (Hampshire: Ashgate Publishing) 14.

Stapleton, Jane. "Two Causal Fictions at the Heart of US Asbestos Doctrine” (2006) 122

Law Quarterly Review.

Stapleton, Jane. “Unnecessary causes” (2013) 129 Law Quarterly Review 39.

Steel, Sandy \& David Ibbetson. "MORE GRIEF ON UNCERTAIN CAUSATION IN TORT” (2011) 70:02 The Cambridge Law Journal 451.

Steve Gold. "Causation in Toxic Torts: Burdens of Proof, Standards of Persuasion, and Statistical Evidence" (1986) 96 Yale Law Journal.

Summers, Robert S. "Pragmatic Instrumentalism in Twentieth Century American Legal

Thought-A Synthesis and Critique of Our Dominant General Theory About Law and Its Use” (1980) 66 Cornell L Rev 861.

Thomas, Michael G. "Causation in Medical Negligence Cases: A Perspective from British Columbia” (2011) 39 Advoc Q 67.

Tony Weir. "Making It More Likely Versus Making It Happen” (2002) 519 CLJ.

Turton, G. “A CASE FOR CLARITY IN CAUSATION?” (2008) 17:1 Medical Law Review 140. 
Turton, Gemma Rosanne. "Sienkiewicz v Greif (UK) Ltd: a cautionary tale for causation." (2011) 27 Professional Negligence 166.

Tversky, Amos \& Daniel Kahneman. "Extensional versus intuitive reasoning: the conjunction fallacy in probability judgment.” (1983) 90:4 Psychological review 293.

UK Department Of Constitutional Affairs. Compensation Act Explanatory Memoranda (Her Majesty's Stationery Office, London, 2006).

Van Hoecke, Mark \& Mark Warrington. “Legal Cultures, Legal Paradigms and Legal

Doctrine: Towards a New Model for Comparative Law" (1998) 47:03 International \& Comparative Law Quarterly 495.

Vaughan Black. “A Farewell to Causation” (2001) 24 Advocates' Quarterly 478.

Vidmar, Neil. "Empirical Evidence on the Deep Pockets Hypothesis: Jury Awards for Pain and Suffering in Medical Malpractice Cases” (1993) 43:2 Duke Law Journal 217.

Walker, Robert. "Developing the Common Law: How Far Is Too Far" (2013) 37 Melb UL

Rev 232.

Weinrib, Ernest J. “Causal Uncertainty” (2015) Oxford Journal of Legal Studies 1.

Weinrib, Ernest J. "Toward a moral theory of negligence law" in Justice, Rights, and Tort Law (Springer, 1983) 123.

Weinrib, Ernest. “A Step Forward in Factual Causation” (1975) 38 Modern Law Review 518. Wendel, W Bradley. "Legal Ethics and the Separation of Law and Morals" (2005) 91 Cornell L Rev 67.

Wiener, Jonathan B. "Whose precaution after all? A comment on the comparison and evolution of risk regulatory systems" (2003) 13:3 Duke Journal of Comparative \& International Law 207. Wright, Cecil. “The Law of Torts, 1923-1947” (1948) 26 Canadian Bar Review 46. 
Wright, Edward. National Trends in Personal Injury Litigation: Before and After "Ipp" (Newcastle, Australia: Justice Policy Research Centre, 2006).

Wright, J Skelly, Alfred Thompson Denning \& Patrick Devlin. "Law and the Logic of Experience: Reflections on Denning, Devlin, and Judicial Innovation in the British Context" (1980) 33:1 Stanford Law Review 179.

Wright, Richard W. “Causation in Tort Law” (1985) 73:6 California Law Review 1735.

Young, Gerald. "Causality and Causation in Law, Medicine, Psychiatry, and Psychology:

Progression or Regression?” (2008) 1:3 Psychological Injury and Law 161.

Zipursky, Benjamin. "Legal malpractice and the structure of negligence law” (1998) 67

Fordham L Rev 649.

Zipursky, Benjamin. “Civil recourse, not corrective justice” (2002) 91 Geo LJ 695. 